\title{
U.S. Geological Survey
}

Middle Rio Grande Basin Study-

Proceedings of the Second Annual Workshop,

Albuquerque, New Mexico,

February 10-11, 1998

Janet L. Slate, editor

U.S. GEOLOGICAL SURVEY

Open-File Report 98-337

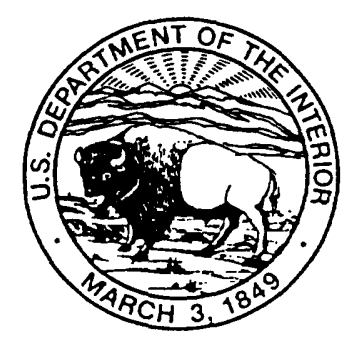




\section{U.S. DEPARTMENT OF THE INTERIOR Bruce Babbitt, Secretary}

U.S. GEOLOGICAL SURVEY

Thomas J. Casadevall, Acting Director

This report is preliminary and has not been reviewed for conformity with U.S. Geological Survey editorial standards (or with the North American Stratigraphic Code).

Any use of trade, product, or firm names in this publication is for descriptive purposes only and does not imply endorsement by the U.S. Government.

Purchase copies of this report from:

U.S. Geological Survey

Branch of Information Services

Box 25286

Denver, CO 80225

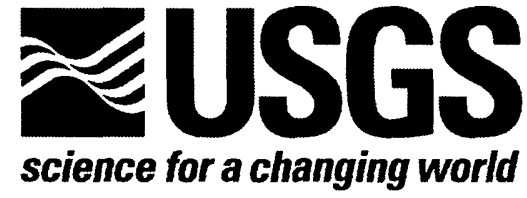




\section{CONTENTS}

INTRODUCTION

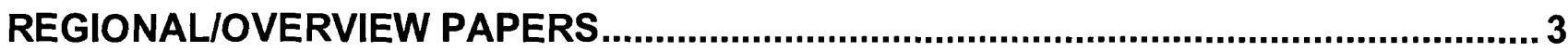

HYDROGEOLOGIC MAPPING IN THE BASIN AND RANGE PROVINCE,

PROGRESS SINCE 1900, AND FUTURE PROSPECTS

John W. Hawley. 3

PROGRESS REPORT ON GEOPHYSICAL STUDIES FOR THE

MIDDLE RIO GRANDE BASIN PROJECT

V.J.S. Grauch, Maria Deszcz-Pan, and Brian Rodriguez.. 7

MODIFICATION AND UPDATE OF ALBUQUERQUE BASIN

GROUND-WATER-FLOW MODEL

Douglas P. McAda and John Michael Kernodle

APPLICATION OF PARAMETER-ESTIMATION METHODS TO THE

GROUND-WATER FLOW MODEL OF THE MIDDLE RIO GRANDE BASIN

Claire R. Tiedeman

USING ENVIRONMENTAL TRACER DATA TO IMPROVE THE U.S. GEOLOGICAL

SURVEY MODFLOW MODEL OF THE MIDDLE RIO GRANDE BASIN

Ward E. Sanford, L. Niel Plummer, and Laura M. Bexfield

TRACING AND DATING GROUND WATER IN THE MIDDLE RIO GRANDE

BASIN, NEW MEXICO-A PROGRESS REPORT

L. Niel Plummer, Ward E. Sanford, Eurybiades Busenberg, Laura M. Bexfield,

Scott K. Anderholm, and Peter Schlosser

NORTHERN MIDDLE RIO GRANDE BASIN

GEOLOGY OF THE COCHITI PUEBLO AREA AND THE CERRILLOS UPLIFT

BASED ON GEOLOGIC MAPPING, AIRBORNE AND GROUND

GEOPHYSICS, AND LIMITED SUBSURFACE INFORMATION

David Sawyer, Maria Deszcz-Pan, V.J.S. Grauch, Gary Smith, David Dethier,

Ren Thompson, Scott Minor, Ralph Shroba, Brian Rodriguez, and Andrika Kuhle

HYDROGEOLOGIC AND TECTONIC SIGNIFICANCE OF NEW GEOLOGICAL

MAPPING IN THE SANTO DOMINGO BASIN AND ADJACENT JEMEZ MOUNTAINS

Gary A. Smith, Andrika J. Kuhle, and William C. McIntosh .

GEOLOGIC MAPS OF THE OJITO SPRINGS, SAN YSIDRO, SKY VILLAGE NE,

AND JEMEZ PUEBLO 7.5-MINUTE QUADRANGLES: RESULTS OF EDMAP AND

STATEMAP EFFORTS IN THE NORTHWESTERN CORNER OF THE ALBUQUERQUE BASIN

F.J. Pazzaglia, M.L. Formento-Trigilio, J.L. Pederson, A.F. Garcia, D.J. Koning, and C. Toya

CHARACTERIZING FAULTS IN THE MIDDLE RIO GRANDE BASIN:

RESULTS FROM THE COCHITI AND SANTO DOMINGO PUEBLOS

Scott A. Minor and Nancy A. Shock

EOLIAN ORIGIN OF SANDY MANTLES ON GENTLY-SLOPING BASALTIC

LAVA FLOWS IN THE PLIOCENE CERROS DEL RIO VOLCANIC FIELD

NEAR SANTA FE, NEW MEXICO—PRELIMINARY FINDINGS

Ralph R. Shroba and Ren A. Thompson

LANDSLIDES OF THE LOS ALAMOS 30' X 60' QUADRANGLE,

NORTHERN NEW MEXICO

P.E. Carrara.

STREAMFLOW LOSS AND INFILTRATION ALONG THE SANTA FE RIVER

NEAR LA BAJADA, NEW MEXICO, JUNE 26-27, 1997

Carole L. Thomas and Jim Constantz 
Surficial \& Subsurface Geology.

PRELIMINARY GEOLOGIC MAPPING IN PARTS OF THE SANTA ANA PUEBLO

AND BERNALILLO NW QUADRANGLES, NORTHERN ALBUQUERQUE BASIN

Stephen F. Personius.

SUBSURFACE STRATIGRAPHY, STRUCTURE, AND HYDROGEOLOGIC

FRAMEWORK OF THE SANTA FE GROUP FROM BOREHOLE GEOPHYSICAL

LOGS, NORTHERN ALBUQUERQUE BASIN, NEW MEXICO

Sean D. Connell, Bruce D. Allen, and John W. Hawley.....

EXPRESSION OF FAULTS IN HIGH-RESOLUTION AEROMAGNETIC DATA

NEAR ALBUQUERQUE, NEW MEXICO-PRELIMINARY RESULTS

V.J.S. Grauch

PRELIMINARY GEOPHYSICAL RESULTS FROM THE RIO RANCHO AREA,

NEW MEXICO

Maria Deszcz-Pan, Brian Rodriguez, V.J.S. Grauch, Byron D. Stone,

David A. Sawyer, and Victor Labson .

ELECTROMAGNETIC SURVEYS IN THE RIO GRANDE FLOODPLAIN,

MIDDLE RIO GRANDE BASIN, NEW MEXICO—SECOND-YEAR STATUS

Joseph M. Sterling and James R. Bartolino

$98^{\text {th }}$ Street Core

THE 98TH STREET CORE: KEY TO ANALYSIS OF SANTA FE GROUP

STRATIGRAPHY AND HYDROGEOLOGY IN THE CENTRAL

MIDDLE RIO GRANDE BASIN

Byron D. Stone and Bruce D. Allen.

PALEOMAGNETIC AND ROCK MAGNETIC STUDIES OF THE UPPER

SANTA FE GROUP: GOALS AND PRELIMINARY RESULTS

M.R. Hudson, Marlo Mikolas, B.D. Allen, and J.W. Geissman ...

SEDIMENT AND GROUND-WATER GEOCHEMISTRY OF THE $98^{\mathrm{TH}} \mathrm{ST}$.

DRILL CORE NEAR ALBUQUERQUE, NEW MEXICO

Mark R. Stanton, David J. Grimes, Richard F. Sanzolone, and Steven S. Sutley

Recharge/Infiltration \& Hydraulic Characteristics

EFFECTS OF BASIN-MARGIN STRUCTURE AND STRATIGRAPHY

ON GROUND-WATER RECHARGE IN THE PLACITAS AREA,

NORTHERN ALBUQUERQUE BASIN, NEW MEXICO

Peggy Johnson, William LeFevre, Andrew Campbell, and Brian McPherson

TEMPERATURE PROFILES OF THE AQUIFER SYSTEM UNDERLYING THE RIO

GRANDE, MIDDLE RIO GRANDE BASIN, NEW MEXICO—SECOND-YEAR STATUS

James R. Bartolino

USE OF SURFACE-WATER PULSES TO ESTIMATE HYDRAULIC CHARACTERISTICS

OF THE RIO GRANDE ALLUVIUM, ALBUQUERQUE AREA, NEW MEXICO

D. Michael Roark

Recharge-Santa Fe River, Bear Canyon, Abo Arroyo Studies

MEASUREMENTS OF TRIBUTARY, INTER-ARROYO, AND MOUNTAIN-FRONT

RECHARGE ON THE SANTA FE RIVER, BEAR CANYON, AND ABO ARROYO,

NEW MEXICO

Jim Constantz

ENVIRONMENTAL TRACERS OF RECHARGE AT ABO ARROYO, BEAR CANYON,

AND THE SANTA FE RIVER, MIDDLE RIO GRANDE BASIN, NEW MEXICO

David A. Stonestrom and Katherine C. Akstin

THERMAL TRACKING TECHNIQUES TO ESTIMATE STREAMFLOW AND

STREAMBED INFILTRATION ALONG THE EASTERN MIDDLE RIO GRANDE BASIN

Amy E. Stewart, Anne D. Ronan, and Jim Constantz 
PRELIMINARY GEOLOGIC, HYDROLOGIC, AND AEROMAGNETIC MAPS

OF THE WESTERN THREE-QUARTERS OF THE PUEBLO OF ISLETA,

CENTRAL NEW MEXICO

Florian Maldonado, Dave W. Love, Janet L. Slate, V.J.S. Grauch, Ward E. Sanford,

Matthew Heizler, William C. McIntosh, and Nancy A. Shock. .61

PRELIMINARY PALEOSEISMIC ANALYSIS OF A TRENCH ACROSS THE

HUBBELL SPRING FAULT NEAR ALBUQUERQUE, NEW MEXICO

Stephen F. Personius.

MOUNTAIN-FRONT RECHARGE ALONG THE EASTERN SIDE

OF THE MIDDLE RIO GRANDE BASIN, CENTRAL NEW MEXICO

Scott K. Anderholm.

PRELIMINARY RESULTS OF AQUIFER-RECHARGE ESTIMATES INTERPRETED

FROM CENTRIFUGE HYDRAULIC PROPERTY MEASUREMENTS,

ABO ARROYO, MIDDLE RIO GRANDE BASIN, NEW MEXICO

Angus M. Lewis and John R. Nimmo

GIS/DIGITAL INFORMATION

THE MIDDLE RIO GRANDE BASIN DIGITAL CARTOGRAPHY PROGRAM

OF THE NEW MEXICO BUREAU OF MINES AND MINERAL RESOURCES

David J. McCraw, Paul W. Bauer, and Glen E. Jones

USING GIS TO PRODUCE A DIGITAL GEOLOGIC MAP: THE LOS LUNAS

QUADRANGLE, AN EXAMPLE FROM THE MIDDLE RIO GRANDE BASIN,

NEW MEXICO

Janet L. Slate and Nancy A. Shock

HISTORICAL MAP RESEARCH FOR THE MIDDLE RIO GRANDE BASIN STUDY

Stewart Wright

URBAN DYNAMICS OF THE MIDDLE RIO GRANDE BASIN

David J. Hester.

MIDDLE RIO GRANDE COUNCIL OF GOVERNMENTS LAND-USE ANALYSIS MODEL

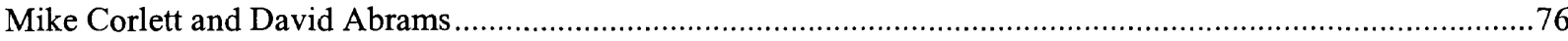

MIDDLE RIO GRANDE COUNCIL OF GOVERNMENTS EXISTING LAND-USE INVENTORY

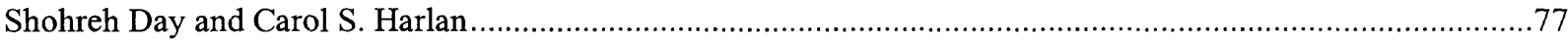

DATA PRODUCTION STATUS FOR THE MIDDLE RIO GRANDE BASIN

Laurie Davis

DESIGN AND DEVELOPMENT OF THE MIDDLE RIO GRANDE BASIN

STUDY WEB PAGES

Mark R. Feller.

ADMINISTRATIVE PAPERS

NEW MEXICO'S STATEMAP PROGRAM: GEOLOGIC QUADRANGLE

MAPPING ALONG THE RIO GRANDE WATERSHED

Paul Bauer.

NEW MEXICO DISTRICT COOPERATIVE PROGRAM

IN THE MIDDLE RIO GRANDE BASIN, FY98

Dennis G. Woodward

MEMORANDUM OF UNDERSTANDING BETWEEN

THE U.S. GEOLOGICAL SURVEY - NATIONAL MAPPING DIVISION AND

THE MIDDLE RIO GRANDE COUNCIL OF GOVERNMENTS OF NEW MEXICO

Lee W. Aggers, Stephen J. Burstein, and David J. Hester

OVERVIEW OF THE FOCUS 2050 REGIONAL PLAN

Dennis R. Foltz and Stephen Burstein 


\section{FIGURES}

1. Geophysical surveys conducted in the Middle Rio Grande Basin

2. Optimal parameter estimates and approximate, linear 95-percent confidence intervals.

Shaded regions are the reasonable range of values for each parameter.

$\mathrm{K}_{\mathrm{LSF}}$ is specified as $2.0 \mathrm{ft} /$ day in representation 4

3. Sketch showing fault zone components.

4. Santa Fe River study area data-collection sites near La Bajada, New Mexico. .................................................22

5. Discharge at TCN1 and TCN2, Santa Fe River near La Bajada. .....................................................................28

6. Albuquerque area and detailed maps of the I40S1 and RBRN2 sections............................................................38

7. Terrain conductivity along the I40S1 and RBRN2 sections. Note the similarity of conductivity values in the I40S1 section and the contrasts between conductivity values for different spacings in the RBRN2 section.

8. Stratigraphic framework of the $98^{\text {th }}$ Street core-hole site. WT, water table; Q, Quaternary period; USF, upper unit of the Santa Fe Group; MSF, middle unit of the Santa Fe Group; MSF Atrisco M., the Atrisco Member of the middle unit of the Santa Fe Group; VA, valley-border alluvial unit

9. Depositional environments for three prominent lithofacies in a faulted alluvial-plain setting..

10. Lithology and geophysical logs for three prominent lithofacies of the $98^{\text {th }}$ Street core.....................................44

11. Location map of the Albuquerque area showing locations of the temperature profile sites.

BRN, Bernalillo site; COR, Corrales site; PDN, Paseo del Norte site; RBR, Rio Bravo site. ...............................51

12. Ground-water temperature profiles drawn from data measured in Corrales piezometer

COR02 and Paseo del Norte piezometer PDN01 ...................................................................................52

13. Map showing site locations, near Rio Bravo Boulevard in Albuquerque. .....................................................54

14. Profiles of water content and pore-water concentrations of chloride and bromide at distances of 5 and 64 meters from Abo Arroyo along a transect near the eastern margin of the Middle Rio Grande Basin, New Mexico.

15. Interarroyo recharge rates inferred from solute profiles along the eastern margin of the Middle Rio Grande Basin, New Mexico.

16. Albuquerque Basin and area where mountain-front recharge was estimated (modified from McAda, 1996).

17. Index map of 7.5-minute quadrangles in the Rio Grande watershed showing New Mexico Bureau of Mines and Mineral Resources STATEMAP quadrangles in progress (1998-1999) and (1997-1998), and completed (1994-1997).

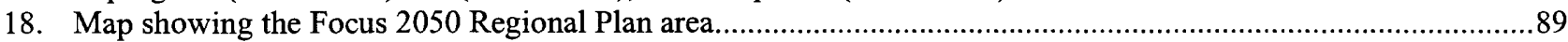

19. Timeline showing activities scheduled for the Focus 2050 Regional Plan process. ........................................90

20. Sketch showing functional plan areas related to the Focus 2050 Regional Plan.................................................90

\section{TABLES}

1. Summary of subsurface representations.

2. Summary of range, variability, and interpretation of terrain-conductivity values for sections I40S1 and RBRN2. 
In 1995, the Water Resources Division (WRD) of the U.S. Geological Survey (USGS) published initial ground-water flow models of the aquifer system in the Albuquerque area that indicated significantly less water available for municipal consumption than previously estimated (Kernodle and others, 1995). Accelerating population growth in the area heightens the concern over water supplies; in the 1990 census, approximately 35 percent (about 565,000 people) of the total population of New Mexico lives within the Middle Rio Grande Basin (MRGB), and the proportion increases annually. In 1996 (FY-96), the USGS launched the 5-year Middle Rio Grande Basin Study, an inter-Divisional and interagency investigation, to delineate regional structural and stratigraphic controls on aquifer extent, and to examine ground-water quality, river-aquifer interactions, and efficacy of recharge.

The major participants in the study are Geologic Division (GD), WRD, and National Mapping Division (NMD) of the USGS, the New Mexico Bureau of Mines and Mineral Resources (NMBMMR), the City of Albuquerque, and the New Mexico Office of the State Engineer. Additional contributing organizations include University of New Mexico, New Mexico Institute of Mining and Technology, Middle Rio Grande Council of Governments (MRGCOG), and numerous counties and Pueblo Nations.

Geologic mapping by GD, NMBMMR, and the universities (largely funded by the USGS National Cooperative Geologic Mapping Program) is providing additional information about the stratigraphic and structural framework of the Santa Fe Group sediments, the principal aquifer units of the basin. High-resolution airborne geophysical surveys by USGS identify detailed fault patterns that could not otherwise be detected due to limited outcrop, and further serve to characterize hydrologic properties of subsurface units. The USGS and the City of Albuquerque jointly funded a drill hole at the $98^{\text {th }}$ Street site to collect a continuous-core sample of these Santa Fe Group sediments; studies of this core have provided benchmark information for stratigraphic studies and correlation of geophysical logs throughout the central Middle Rio Grande basin (Stone and others, 1998). These results contribute to an improved ground-water flow model for the basin that is under development by WRD, the City of Al- buquerque, and the New Mexico Office of the State Engineer. Hydrologic studies by these organizations are investigating aquifer properties, various components of recharge to the ground-water system, and interactions between the Rio Grande and the aquifers in order to understand the overall water budget of the system. A joint study between MRGCOG and NMD is investigating historical patterns of land-use change in the metropolitan areas and evaluating impacts of various growth scenarios for the region.

These Proceedings are summaries of work presented at the $2^{\text {nd }}$ Annual Middle Rio Grande Basin Study Workshop held in Albuquerque, New Mexico, on February 10-11, 1998. The first six papers in the volume are regional in scope and provide overviews of: hydrogeologic mapping in the Basin and Range province (Hawley); geophysical studies in the MRGB (Grauch and others); the initial WRD groundwater flow model (McAda) and techniques that bear on ground-water flow model calibration including parameter-estimation methods (Tiedeman), environmental tracer data (Sanford and others), and tracing and dating of ground water (Plummer and others).

The next three sections of the volume include reports of studies in different geographic sectors of the MRGB. The northern part of the MRGB Study comprises all of the 1:100,000-scale Los Alamos sheet, the western part of the Santa Fe sheet, and the northwestern and northeastern parts of the Albuquerque sheet. Research reported in the first five papers include studies near the Pueblos of Cochiti, Santo Domingo, and Jemez-geologic mapping (Sawyer and others; Smith and others; Pazzaglia and others), fault characterization (Minor and Shock), and soil genesis studies (Shroba and Thompson). A landslide inventory encompasses a greater portion of the Los Alamos sheet (Carrara). Part of a larger study on recharge in three areas of the MRGB, Thomas and Constantz report on streamflow loss and infiltration along the Santa Fe River.

The central part of the MRGB area includes the principal populated areas of Albuquerque, Bernalillo, and Rio Rancho, and studies in this area are organized as: Surficial and Subsurface Geology, and Recharge/Infiltration and Hydraulic Charac- 
teristics. Papers on surficial and subsurface geology report on geologic mapping (Personius), subsurface stratigraphy, structure, and hydrogeologic framework (Connell and others), faults expressed in aeromagnetic data (Grauch), geophysical results from the Rio Rancho surveys (Deszcz-Pan and others), and ground-based electromagnetic surveys to explore the distribution and geometry of silty-clay layers in the inner river valley (Sterling and Bartolino). Three papers report on studies of the $9^{\text {th }}$ Street drill-hole core: stratigraphy and hydrogeology (Stone and Allen), paleomagnetism and magnetostratigraphy (Hudson and others), and sediment and ground-water geochemistry (Stanton and others). Recharge/Infiltration and Hydraulic Characteristics papers include reports on: the effects of structure and stratigraphy on recharge (Johnson and others); temperature profiles to model hydraulic conductivity and estimate recharge (Bartolino); and the use of surfacewater pulses to estimate hydraulic characteristics (Roark). Recharge studies in all three geographic areas of the MRGB are reported from study sites in Santa Fe River (Los Alamos sheet), in Bear Canyon (Albuquerque sheet), and in Abo Arroyo (Belen sheet). Constantz provides an overview of current studies in these three areas. Stonestrom and Akstin report on the environmental tracers of recharge, and Stewart and others use thermal tracking techniques to estimate infiltration.

Studies of geology in the southern part of the MRGB, largely within the Belen 100k sheet include Maldonado and others' summary of geologic, hydrologic, and aeromagnetic data for the Isleta Pueblo, and Personius' report of paleoseismic analysis of relations exposed by a trench across the Hubbell Spring fault. Recharge studies along the mountain front of the Manzanos (Anderholm) and Abo Arroyo (Lewis and Nimmo) conclude this section.

Digital information and Geographic Information Systems (GIS) studies are integral to all areas of the MRGB. McCraw and others report on the digital cartography program of the NMBMMR. Slate and Shock describe GIS techniques employed to produce a digital geologic map database. Historical map research (Wright) is used by Hester to model changes and trends in urban land-use patterns. The Middle Rio Grande Council of Governments (MRGCOG) is constructing a land-use analysis model (Corlett and Abrams) and an existing land-use inventory (Day and Harlan). Davis gives an overview of the data production status of the NMD. The MRGB web page <http://rmmcweb.cr.usgs.-gov/public/mrgb/> design and development are discussed by webmaster Feller.

The final section of the volume consists of reports on administrative aspects of the interagency MRGB Study and activities of cooperating organizations. The STATEMAP Program of the NMBMMR covers the status of geologic mapping along the Rio Grande watershed (Bauer). Woodward highlights accomplishments of the jointly funded Cooperative Program of the New Mexico District of WRD with various entities in the basin. Aggers and others describe a memorandum of understanding between NMD and MRGCOG for modeling changes in urban land-use patterns and future forecasts. Several scenarios for future land-use patterns are modeled by MRGCOG for their Focus 2050 Regional Plan (Foltz and Burstein).

\section{REFERENCES}

Kernodle, J.M., McAda, D.P., and Thorn, C.R., 1995, Simulation of ground-water flow in the Albuquerque Basin, central New Mexico: U.S. Geological Survey Water-Resources Investigations Report 94-4251, 114 p.

Stone, B.D., Allen, B.D., Mikolas, Marlo, Hawley, J.W., Haneberg, W.C., Johnson, P.S., Allred, Barry, and Thorn, C.R., 1998, Preliminary lithostratigraphy, interpreted geophysical logs, and hydrogeologic characteristics of the $98^{\text {th }}$ Street core hole, Albuquerque, New Mexico: U.S. Geological Survey Open-File Report 98-210, 82 p. 


\title{
HYDROGEOLOGIC MAPPING IN THE BASIN AND RANGE PROVINCE, PROGRESS SINCE 1900, AND FUTURE PROSPECTS
}

\author{
John W. Hawley \\ New Mexico Bureau of Mines and Mineral Resources \\ New Mexico Institute of Mining and Technology \\ 2808 Central Ave., S.E., Albuquerque, NM 87106 \\ $<$ rcase@admin.nmt.edu $>$
}

Making a four-dimensional conceptual model that accurately portrays the material, genetic, spatial and temporal attributes of the earth's outer crust is definitely not a trivial pursuit. Several exemplary human traits characterize a successful geologic mapper: scientific and artistic achievement, perseverance, chutzpah, and, most important, a longstanding love affair with this planet.

Because of the major role that ground water plays in the use of land and water resources of the Basin and Range province, hydrogeologists have and always will be attracted to the region, like bees to honey or bugs to bait. The early generation of geologic mappers (e.g., Powell, King, Gilbert, Russell, Dutton) served a nation bent on rapid "settlement" and exploitation of the region's natural resources in an era of "manifest destiny." A solid foundation was laid, however, in that period of foot, horse, and steam-powered field transportation for future "geomappers." Advances in drilling technology and local availability of deep-subsurface data after 1900 allowed mapping of basin and valley fills in the three-dimensional context of modern hydrogeologic models that integrate surface and subsurface information on tectonic framework, stratigraphy and lithofacies distribution. Early (1907-1918) efforts in hydrogeologic mapping and conceptual model development in the Basin and Range province are illustrated by U.S. Geological Survey (USGS) Bulletins, Water-Supply Papers, and Folios by Bryan, Darton, Lee, Meinzer, Schwennesen, Siebenthal, and others (e.g., Lee, 1907; Siebenthal, 1910; Meinzer, 1911, 1916, 1917, Meinzer and Kelton, 1912; Meinzer and Hare, 1915; Darton, 1916; Schwennesen, 1918a, 1918b; Bryan, 1923; and Waring and Meinzer, 1947).
Tolman (1909) recognized the fundamental hydrogeologic distinction between depositional systems in aggrading basins with internal surface drainage and those with external surface- and ground-water discharge (his bolson and semibolson systems). He (Tolman, 1937) and Kirk Bryan (1909, 1923, 1938) were among the first to effectively describe the complex interplay between piedmont-slope and basin-floor depositional systems (bajada, alluvial flat, lake, playa, and axial-fluvial) in the context of the geohydrology and geomorphology of Neogene fault-block basins. Work initiated in the Rio Grande rift by Bryan and his students has been of particular significance in the development of modern conceptual models of aquifer systems of the Middle Rio Grande Basin (e.g., Bryan and McCann, 1937, 1938; Upson, 1939; Wright, 1945; Stearns, 1953).

The major scientific and technological breakthroughs during and immediately after World War II, including development of modern geophysicalsurvey and deep-drilling methods, and advances in geochemistry, introduced a new era of hydrogeologic system characterization that continues today. Mapping of basin-fill aquifer systems in southern and central Nevada by G.B. Maxey and students, in cooperation with the USGS - Water Resources Division (WRD), are representative of work in the Great Basin prior to 1970 (e.g., Maxey and Jameson, 1948; Maxey and Shamberger, 1961; Dudley and McGinnis, 1962; Bredehoeft, 1963; Cohen et al., 1965; Hawley and Wilson, 1965; Maxey and Farvolden, 1965; Cohen, 1966; Maxey, 1968; Mifflin, 1968, 1988). Concurrent studies in the El Paso region by NMSU, the Texas Water Commission, USGSWRD, and City of El Paso illustrate innovations in subsurface mapping using borehole geophysics and aquifer geochemistry (Knowles and Kennedy, 1956; Leggat et al., 1962; Cliett, 1969; Hawley et al., 1969; 
King et al., 1971). Hydrogeologic mapping and related hydrologic and geologic investigations in north-central basins of the Rio Grande rift is exemplified by the work of Bjorklund and Maxwell, 1961; Spiegel, 1961, 1962; Titus, 1961, 1963; Spiegel and Baldwin, 1963; and Lambert, 1968.

Recent and future hydrogeologic mapping has been and will be characterized by the increased availability of high-quality geophysical and geochemical data, and deep-borehole sample and core logs. The opportunities generated by the exponentially increasing power of computers, and evolution of numerical modeling and GIS technology already dominates this era.

In the Basin and Range province, the bridge between the Darton-Meinzer-Bryan-Tolman-Maxey conceptual world and the present will continue to be hydrogeologic ground truth. Our surface and underground view of Mother Nature's hydrologic systems must now be expressed in units that modelers of ground-water flow systems can understand and computers can process. The recent improvements in our understanding of subsurface geophysical and geochemical systems, geochronology, and the definition of hydrostratigraphic units (Seaber, 1988), lithofacies properties, and structural boundary conditions now allow modelers to effectively join forces with hydrogeologists, geophysicists and geochemists in meeting the incredible water-resource challenges that face Third Millennium society in this and other arid regions. Recent basic and applied research that directly relates to hydrogeologic mapping of Rio Grande rift basins is illustrated by the works of Kelley (1977), Bachman and Mehnert (1978), Cordell (1978), Hawley (1978), Machette (1978), Seager and Morgan (1979), Gile et al. (1981), Wilson et al. (1981), Birch (1982), Seager et al. (1984, 1987), Lozinsky (1986, 1994), Anderholm (1988), Barroll and Reiter (1990), Frenzel and Kaehler (1990), Mack and Seager (1990), Lozinsky and Tedford (1991), Haase (1992), Haase and Lozinsky (1992), Hawley and Haase (1992), Hawley and Longmire (1992), Hawley and Lozinsky (1992), Kernodle (1992), Thorn et al. (1993), Chapin and Cather (1994), Keller and Cather (1994), Haneberg (1995a, 1995b, 1998), Hawley et al. (1995), Kernodle et al. (1995), Hansen and Gorbach (1997), and Woodward and Myers (1997).

\section{REFERENCES}

Anderholm, S.K., 1988, Ground-water geochemistry of the Albuquerque-Belen Basin, central New Mexico: U.S. Geological Survey Water-Resources Investigations Report 86-4094, $100 \mathrm{p}$.

Bachman, G.O., and Mehnert, H.H., 1978, New K-Ar dates and late Pleistocene and Holocene geomorphic history of the central Rio Grande region, New Mexico: Geological Society of America Bulletin, v. 89, p. 283-292.

Barroll, M.W. and Reiter, M., 1990, Analysis of the Socorro hydrogeothermal system, central New Mexico: Journal of Geophysical Research, v. B95, p. 21,949-21,963.

Birch, F.S., 1982, Gravity models of the Albuquerque Basin, Rio Grande rift, New Mexico: Geophysics, v. 47, no. 8, p. 1185-1197.

Bjorklund, L.J., and Maxwell, 1961, Availability of ground water in the Albuquerque area, Bernalillo and Sandoval Counties, New Mexico: New Mexico State Engineer, Technical Report 21, 117 p.

Bredehoeft, J.D., 1963, Hydrogeology of the lower Humboldt River basin, Nevada: Nevada Department of Conservation and Natural Resources Bulletin 21, $50 \mathrm{p}$.

Bryan, K., 1909, Geology of the vicinity of Albuquerque: University of New Mexico Bulletin 51, Geological Series, v. 3 , no. 1,24 p.

Bryan, K., 1923, Erosion and sedimentation in the Papago Country, Arizona: U.S. Geological Survey Bulletin 730, p. 19-90.

Bryan, K., 1938, Geology and groundwater conditions of the Rio Grande depression in Colorado and New Mexico, in U.S. Natural Resources Planning Board, The Rio Grande Joint Investigations in the Rio Grande Basin: Washington, D.C., U.S. Government Printing Office, v. 1, pt. 2, p. 197-225.

Bryan, K., and McCann, F.T., 1937, The Ceja de Rio Puerco: A border feature of the Basin and Range province in New Mexico, Part I: Journal of Geology, v. 45, p. 801-828.

Bryan, K., and McCann, F.T., 1938, The Ceja de Rio Puerco: A border feature of the Basin and Range province in New Mexico, Part II: Journal of Geology, v. 46, p. 1-16.

Chapin, C. E., and Cather, S. M., 1994, Tectonic setting of the axial basins of the northern and central Rio Grande rift: Geological Society of America Special Paper 291, p. 5-25. 
Cliett, T., 1969, Groundwater occurrence of the E1 Paso area and its related geology: New Mexico Geological Society, $20^{\text {th }}$ Field Conference Guidebook, p. 209-214.

Cohen, P., 1966, Water in the Humboldt River Valley near Winnemucca, Nevada: U.S. Geological Survey WaterSupply Paper 1816, $69 \mathrm{p}$.

Cohen, P., and others, 1965, Water resources of the Humboldt River Valley near Winnemucca, Nevada: U.S. Geological Survey Water-Supply Paper 1795, 143 p.

Cordell, L., 1978, Regional geophysical setting of the Rio Grande rift: Geological Society of America Bulletin, v. 89, p. 1073-1090.

Darton, N.H., 1916, Geology and underground water of Luna County, New Mexico: U.S. Geological Survey Bulletin $618,188 \mathrm{p}$.

Dudley, W.W. and McGinnis, L.D., 1962, Seismic refraction and earth resistivity investigations of hydrogeologic problems in the Humboldt River basin, Nevada: University of Nevada, Reno, Desert Research Institute Technical Report $1,29 \mathrm{p}$.

Frenzell, P.F. and Kaehler, C.A., 1992, Geohydrology and simulation of ground-water flow in the Mesilla Basin, Doña Ana County, New Mexico and El Paso County, Texas: U.S. Geological Survey Professional Paper 1407-C, 105 p.

Gile, L.H., Hawley, J.W., and Grossman, R.B., 1981, Soils and geomorphology in the Basin and Range area of southern New Mexico-guidebook to the Desert Project: New Mexico Bureau of Mines and Mineral Resources, Memoir 33, $222 \mathrm{p}$.

Haase, C.S., 1992, Borehole geophysical data, in Hydrogeologic framework of the northern Albuquerque Basin: New Mexico Bureau of Mines and Mineral Resources, Open-File Report 387, p. V-1 to V-18.

Haase, C.S., and Lozinsky, R.P., 1992, Estimation of hydrologic parameters, in Hydrogeologic framework of the northern Albuquerque Basin: New Mexico Bureau of Mines and Mineral Resources, Open-File Report 387, p. VI-1 to VI-13.

Haneberg, W.C., (ed.), 1995a, Albuquerque Basin studies in hydrogeology: New Mexico Geology, v. 17, no. 4, p. 6193.

Haneberg, W.C., 1995b, Steady state groundwater flow across idealized faults: Water Resources Research, v. 31, no. 7 , p. $1915-1820$.

Haneberg, W.C., (ed.), 1998, Albuquerque Basin-Studies in hydrogeology II: New Mexico Geology, v. 20, no. 1, p. 127.

Hansen, S., and Gorbach, C., 1997, Middle Rio Grande water assessment: Hydrogeologic framework: U.S. Bureau of Reclamation, Albuquerque Area Office, Final Report, Chapter 2, p. 2-1 to 2-21.

Hawley, J.W., (compiler), 1978, Guidebook to the Rio Grande rift in New Mexico and Colorado: New Mexico Bureau of Mines and Mineral Resources, Circular 163, $241 \mathrm{p}$.

Hawley, J.W., and Wilson, W.E., 1965, Quaternary geology of the Winnemucca area, Nevada: University of Nevada, Reno, Desert Research Institute, Technical Report No. 5, 66 p.

Hawley, J.W., and Haase, C.S., 1992, (compilers), Hydrogeologic framework of the northern Albuquerque Basin: New Mexico Bureau of Mines and Mineral Resources, Open-File Report 387, 74 p., 8 Appendices, Glossary.

Hawley, J.W., and Longmire, P.A., 1992, Site characterization and selection (Chapter 3), in Reith, C.C., and Thomson, B.M., (eds.), Deserts as dumps? The disposal of hazardous materials in desert ecosystems: Albuquerque, University of New Mexico Press, p. 57-99.

Hawley, J.W., and Lozinsky, R.P., 1992, Hydrogeologic framework of the Mesilla Basin in New Mexico and western Texas: New Mexico Bureau of Mines and Mineral Resources, Open-File Report 323, 55 p.

Hawley, J.W., Haase, C.S., and Lozinsky, R.P., 1995, An underground view of the Albuquerque Basin, New Mexico, in Ortega-Klett, C.T., (ed.), Proceedings of the $39^{\text {th }}$ Annual New Mexico Water Conference, "The water future of Albuquerque and Middle Rio Grande Basin": New Mexico Water-Resources Research Institute Report 290, p. 37-55.

Hawley, J.W., Kottlowski, F.E., Seager, W.R., King, W.E., Strain, W.S., and LeMone, D.V., 1969, The Santa Fe Group in the south-central New Mexico border region: New Mexico Bureau of Mines and Mineral Resources, Circular 104 , p. $235-274$.

Keller, G.R., and Cather, S.M., (eds.), 1994, Basins of the Rio Grande rift: Structure, stratigraphy, and tectonic setting: Geological Society of America Special Paper 291.

Kelley, V.C., 1977, Geology of the Albuquerque Basin, New Mexico: New Mexico Bureau of Mines and Mineral Resources Memoir 33, $66 \mathrm{p}$.

Kernodle, J.M., 1992, Summary of U.S. Geological Survey ground-water-flow models of basin-fill aquifers in the southwestern alluvial basins region, Colorado, New Mexico, and Texas: U.S. Geological Survey, Open-File Report 90-361, $81 \mathrm{p}$.

Kernodle, J.M., McAda, D.P., and Thorn, C.R., 1995, Simulation of ground-water flow in the Albuquerque Basin, central New Mexico: U.S. Geological Survey Water-Resources Investigations Report 94-4251, 114 p. 
King, W.E., Hawley, J.W., Taylor, A.M., and Wilson, R.P., 1971, Geology and ground-water resources of central and western Doña Ana County, New Mexico: New Mexico Bureau of Mines and Mineral Resources, Hydrologic Report $1,64 \mathrm{p}$.

Knowles, D.B. and Kennedy, R.A., 1956, Ground-water resources of the Hueco Bolson, northeast of El Paso, Texas: Texas Board of Water Engineers, Bulletin 5615, 265 p.

Lambert, P.W., 1968, Quaternary stratigraphy of the Albuquerque area, New Mexico: unpublished Ph.D. dissertation, Albuquerque, University of New Mexico, $329 \mathrm{p}$.

Lee, W.T., 1907, Water resources of the Rio Grande Valley in New Mexico: U.S. Geological Survey Water-Supply Paper $188,59 \mathrm{p}$.

Leggat, E.R., Lowry, M.E., and Hood, J.W., 1962, Ground-water resources in the lower Mesilla Valley, Texas and New Mexico: Texas Board of Water Engineers, Bulletin 6203, 191 p.

Lozinsky, R.P., 1986, Geology and late Cenozoic history of the Elephant Butte area, Sierra County, New Mexico: New Mexico Bureau of Mines and Mineral Resources, Circular 197, $40 \mathrm{p}$.

Lozinsky, R.P., 1994, Cenozoic stratigraphy, sandstone petrology, and depositional history of the Albuquerque Basin, central New Mexico: Geological Society of America Special Paper 291, p. 73-81.

Lozinsky, R.P. and Tedford, R.H., 1991, Geology and paleontology of the Santa Fe Group, southwestern Albuquerque Basin, Valencia County, New Mexico: New Mexico Bureau of Mines and Mineral Resources, Bulletin 132, 35 p.

Machette, M.N., 1978, Geologic map of the San Acacia quadrangle, Socorro County, New Mexico: U.S. Geological Survey, Geologic Quadrangle Map GQ 1415, scale 1:24,000.

Mack, G.H., and Seager, W.R., 1990, Tectonic control on facies distribution of the Camp Rice and Palomas Formations (Pliocene-Pleistocene) in the southern Rio Grande rift: Geological Society of America Bulletin, v. 102, p. 45-53.

Maxey, G.B., 1968, Hydrogeology of desert basins: Ground Water, v. 6, no. 5, 13 p.

Maxey, G.B. and Farvolden, R.N., 1965, Hydrogeologic factors in problems of contamination of arid lands: Ground Water, v. 3, no. 4, p. 29-32.

Maxey, G.B., and Jameson, C.H., 1948, Geology and water resources of Las Vegas, Pahrump, and Indian Springs Valleys, Clark and Nye Counties, Nevada: Nevada Office of State Engineer Water Resources Bulletin No. 5, 43 p.

Maxey, G.B., and Shamberger, H.A., 1961, The Humboldt River research project: International Association of Scientific Hydrology Publications 57, p. 438-454.

Meinzer, O.E., 1911, Geology and water resources of Estancia Valley, New Mexico: U.S. Geological Survey WaterSupply Paper 275, 89 p.

Meinzer, O.E., 1916, Ground water in Big Smoky Valley, Nevada: U.S. Geological Survey Water-Supply Paper 375, p. 85-116.

Meinzer, O.E., 1917, Geology and water resources of Big Smoky, Clayton, and Alkali Spring Valleys, Nevada: U.S. Geological Survey Water-Supply Paper 423.

Meinzer, O.E. and Hare, R.E., 1915, geology and water resources of Tularosa Basin New Mexico: U.S. Geological Survey Water-Supply Paper 343, $317 \mathrm{p}$.

Meinzer, O.E. and Kelton, F.C., 1912, Geology and water resources of Sulphur Spring Valley, Arizona: U.S. Geological Survey Water-Supply Paper 320, 231 p.

Mifflin, M.O., 1968, Delineation of ground-water flow systems in Nevada: Desert Research Institute, Technical Report Series H-W, no. 4, $111 \mathrm{p}$.

Mifflin, M.O., 1988, Region 5, Great Basin II. Hydrogeologic regions, in Bach, W., Rosenshein, J.S. and Seaber, P.R., (eds.), Hydrogeology: Geological Society of America, The Geology of North America, v. 0-2, p. 69-78.

Schwennesen, A.T., 1918a, Ground water in the Animas, Playas, Huachita, and San Luis Basins, New Mexico: U.S. Geological Survey Water-Supply Paper 422, 35 p.

Schwennesen, A.T., 1918b, Ground water in San Simon Valley, Arizona and New Mexico: U.S. Geological Survey Water-Supply Paper 425, p. 1-35.

Seaber, P.R., 1988, Hydrostratigraphic units, in Bach, W., Rosenshein, J.S. and Seaber, P.R., (eds.), Hydrogeology: Geological Society of America, The Geology of North America, v. 0-2, p. 69-78.

Seager, W.R. and Morgan, P., 1979, Rio Grande rift in southern New Mexico, West Texas, and Northern Chihuahua, in Riecker, R.E., (ed.), Rio Grande Rift: Tectonics and Magmatism: Washington, D.C., American Geophysical Union, p. 87-106.

Seager, W.R., Shafiqullah, M., Hawley, J.W., and Marvin, R.G., 1984, New K-Ar dates from basalts and the evolution of the southern Rio Grande rift: Geological Society of America, Bulletin, v. 95, p. 87-99.

Seager, W.R., Hawley, J.W., Kottlowski, F.E., and Kelly, S.A., 1987, Geologic map of east half of Las Cruces and northeast El Paso $1^{\circ} \times 2^{\circ}$ sheets, New Mexico: New Mexico Bureau of Mines and Mineral Resources, Geologic Map 57, scale 1:125,000, 3 sheets.

Siebenthal, C.E., 1910, Geology and ground-water resources of the San Luis Valley, Colorado: U.S. Geological Survey Water-Supply Paper 240, 128 p. 
Spiegel, Z., 1961, Late Cenozoic sediments of the lower Jemez River region: New Mexico Geological Society, $12^{\text {th }}$ Field Conference Guidebook, p. 132-138.

Spiegel, Z., 1962, Hydraulics of certain stream-connected aquifer systems: New Mexico State Engineer, Special Report, $105 \mathrm{p}$.

Spiegel, Z., and Baldwin, B., 1963, Geology and water resources of the Santa Fe area, New Mexico: U.S. Geological Survey Water-Supply Paper 1525, 258 p.

Stearns, C.E., 1953, Tertiary geology of the Galisteo-Tonque area, New Mexico: Geological Society of America Bulletin, v. 64, p. 459-508.

Thorn, C.R., McAda, D.P., and Kernodle, J.M., 1993, Geohydrologic framework and hydrologic conditions in the Albuquerque Basin, central New Mexico: U.S. Geological Survey Water-Resources Investigations Report 93-4149, 106 p.

Titus, F.B., Jr., 1961, Ground-water geology of the Rio Grande trough in north-central New Mexico, with sections on the Jemez Caldera and Lucero Uplift: New Mexico Geological Society, $12^{\text {th }}$ Field Conference Guidebook, p. 186-192.

Titus, F.B., Jr., 1963, Geology and ground-water conditions in eastern Valencia County, New Mexico: New Mexico Bureau of Mines and Mineral Resources, Ground-Water Report 7, 113 p.

Tolman, C.F., 1909, Erosion and deposition in the southern Arizona bolson region: Journal of Geology, v. XVII, no. II, p. 136-163.

Tolman, C.F., 1937, Ground Water: New York, McGraw-Hill Book Co. Inc., 593 p.

Upson, J.E., 1939, Physiographic subdivisions of the San Luis Valley, southern Colorado: Journal of Geology, v. 47, no. 7 (reprinted in New Mexico Geological Society $22^{\text {nd }}$ Field Conference Guidebook, p. 113-122).

Waring, G.A. and Meinzer, O.E., 1947, Bibliography and index of publications relating to ground water prepared by the Geological Survey and cooperative agencies: U.S. Geological Survey Water-Supply paper 992, 412 p.

Wilson, C.A., White, R.R., Orr, R.B., and Roybal, R.G., 1981, Water resources of the Rincon and Mesilla Valleys and adjacent areas, New Mexico: New Mexico State Engineer Technical Report 43, 514 p.

Woodward, D.G. and Myers, R.G., 1997, Seismic investigations of the buried horst between the Jornada del Muerto and Mesilla ground-water basins, near Las Cruces, Doña Ana County, New Mexico: U.S. Geological Survey WaterResources Investigations Report 97-4147, 45 p.

Wright, H.E., Jr., 1945, Tertiary and Quaternary geology of the lower Rio Puerco area, New Mexico: Geological Society of America Bulletin, v. 57, p. 383-456.

\title{
PROGRESS REPORT ON GEOPHYSICAL STUDIES FOR THE MIDDLE RIO GRANDE BASIN PROJECT
}

\author{
V.J.S. Grauch, Maria Deszcz-Pan, and Brian Rodriguez \\ U.S. Geological Survey, Mineral Resources Team \\ Box 25046, MS 964, Denver, CO 80225
}

Geophysical studies for the Middle Rio Grande Basin project include acquisition of various types of geophysical data and interpretation of these data in conjunction with geologic, seismic, hydrologic, and other subsurface information. They are designed to improve the understanding of the subsurface hydrogeology of the Basin and thereby improve the hydrologic model, especially to the north and south of Albuquerque where subsurface information is sparse. We have developed a three-pronged approach to accomplish this goal:

Magnetic studies to locate previously unknown or better define previously known faults and facies changes within the basin fill that may control ground-water flow;

Electrical studies to define the three-dimensional extent of hydrogeologic units in the Santa Fe Group aquifer system, especially the axial river channel facies; and

Gravity studies to determine major basement faults and aid interpretation of the regional structure and tectonic framework of the Basin.

\section{Magnetic Studies}

Closely sampled magnetic maps show variations in the magnetic properties of surface and subsurface earth and manmade materials. Variations in the magnetic properties of earth materials arise primar- 
ily from differences in the quantities of magnetic minerals and their magnetic properties. The maps also show responses from anthropogenic features, such as buildings, landfills, and pipelines with cathodic protection.

High-resolution aeromagnetic surveys were conducted north and west of Albuquerque in late 1996 (Rio Rancho and Albuquerque West surveys, Fig. 1), and south and west of Albuquerque in late 1997 (Kirtland/Sandia and Isleta surveys, Fig. 1). Only preliminary data are currently available for the 1997 surveys. Images of the 1996 survey data can be viewed with a web browser at <http://rmmcweb.cr.usgs.gov/public/mrgb/airborne.html>. surface. On the other hand, many exposed faults are not expressed magnetically. Two general types of magnetic signatures of faults can be recognized. One type indicates offset between units of different magnetic properties. These faults can be used to help define cells within the hydrologic model of the basin. The other type indicates lower magnetic values (combined with offset) in a zone surrounding the fault. The lowered values suggest that the material near the fault is different from the surrounding material, and perhaps has different permeability. Two faults that are known hydrologic barriers exhibit the second signature, which suggests a relation between the magnetic signature and reduced permeability.

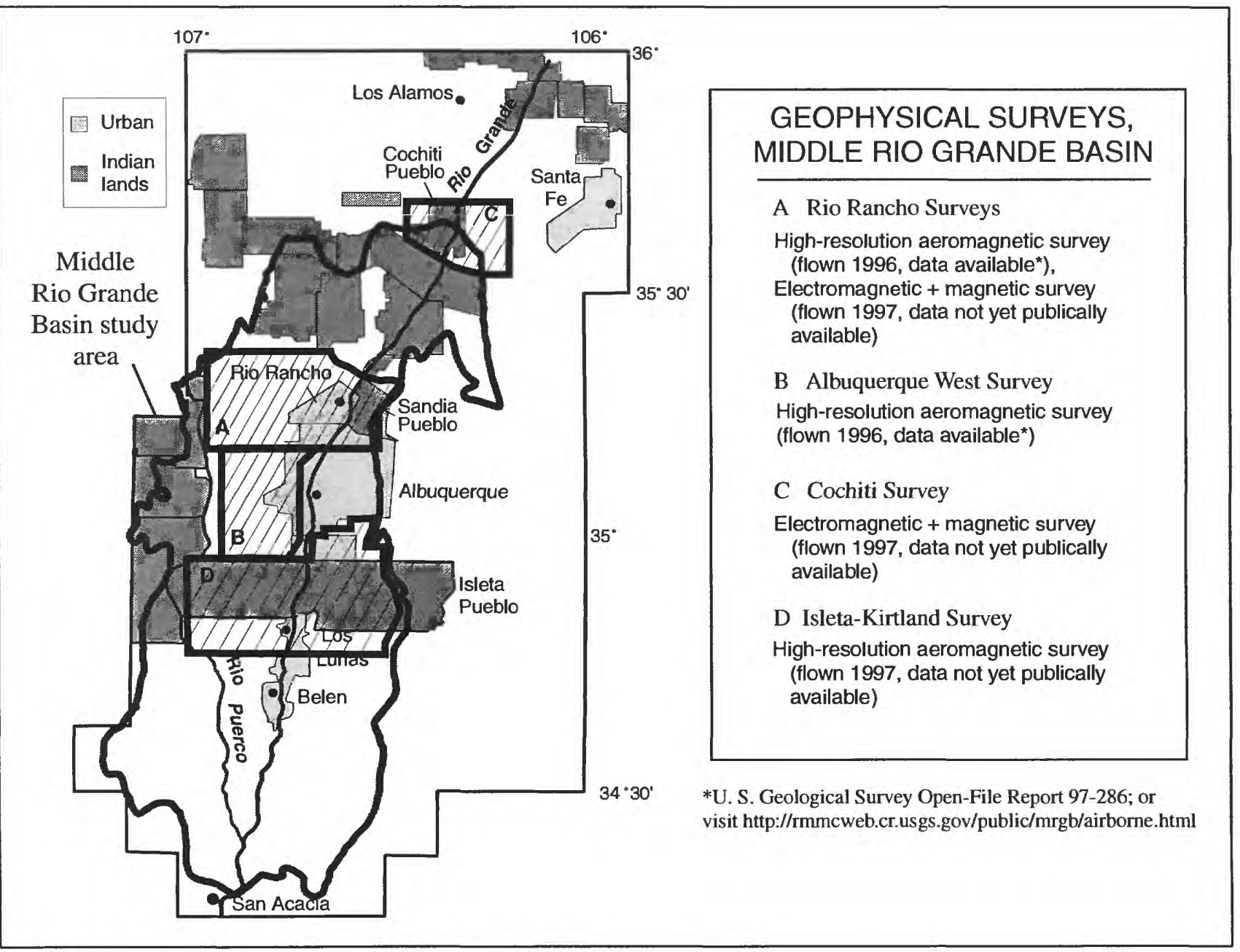

Figure 1. Geophysical surveys conducted in the Middle Rio Grande Basin.

Maps from the surveys show expressions of faults, volcanic rocks, and lithologic variations within the sediments of the Santa Fe Group aquifer system. The expressions of faults are the most striking, revealing many faults that cannot be observed at the
Future work includes examination of specific faults to help determine: (1) the magnetic properties that give rise to the magnetic signature; (2) the mechanism by which magnetic values are lowered in some faults; and (3) the relation (if any) between the mag- 
netic signature and hydrologic properties of the fault. Acquisition of additional high-resolution aeromagnetic data is in the planning stages.

\section{Electrical Studies}

Electrical and electromagnetic methods are used to examine the electrical resistivity (or its inverse, electrical conductivity) of the subsurface. Resistivities of unaltered igneous rocks are generally high. Fracture zones and faults that contain clays or water reduce the resistivity. Resistivities of poorly consolidated sediments are primarily determined by rock porosity, the electrical resistivity of the pore substance, and the presence of certain electrically conductive minerals, such as clays.

Airborne time-domain electromagnetic (TDEM) and magnetic data were acquired in early 1997 over the Rio Rancho and Cochiti survey areas (Fig. 1). Only preliminary data are currently available. Other electrical data were acquired on the ground (audiomagnetotelluric and DC resistivity methods) to help calibrate the results of the airborne survey and to acquire subsurface resistivity information in developed areas where metal, power lines, and electronic equipment interfered with the airborne data acquisition. Electrical logs are also available from scattered drill holes in the Rio Rancho survey area, and from one drill hole in the Cochiti survey area.

The airborne TDEM method has been available for many years for use primarily in mining exploration. Its application to mapping subtle resistivity variations due to hydrostratigraphic variations is new and not well understood. As a result, inversion of the raw data into a credible picture of earth resistivity with depth has not yet been accomplished. Instead, we have used color maps of the raw data (voltage responses) to determine the feasibility of the airborne method to map hydrostratigraphic units within the Santa Fe Group sediments. These maps show good correlation between gross patterns and the general distribution of subsurface lithologic units determined from drill-hole information. In particular, the pattern of voltage values in the Rio Rancho data corresponds well to the lateral distri- bution of the axial river-channel facies north of Albuquerque.

Future work includes: (1) development of a computer algorithm to invert the raw data into resistivity-depth information; (2) continued calibration with ground electrical data and borehole resistivity logs; and (3) lithologic interpretation of and correlation between borehole geophysical logs for comparison with modeled resistivity values.

\section{Gravity Studies}

Gravity data reflect variations in rock density that are primarily a function of rock type. The low density of the poorly consolidated basin fill compared to the moderate to high densities of the surrounding bedrock produce a good contrast in gravity values in the Middle Rio Grande Basin. Steep gravity gradients occur at the edges of the Basin where faults juxtapose basin fill against bedrock. The lower gravity values generally correspond to thicker fill. A previously constructed model of the elevation of the basin floor (crystalline basement) gives values in the deepest parts of sub-basins that range from about $2600 \mathrm{~m}$ deep on the south to $4800 \mathrm{~m}$ deep on the north. However, this model was constructed with earlier gravity data and without benefit of seismic reflection data that have since been released.

In mid-1997, gravity data were acquired as part of a project at the University of Texas-El Paso in collaboration with the Middle Rio Grande Basin geophysical studies. The new data, which are not yet available, fill a large gap in data coverage at the southwestern part of the Basin and will better define the shape of the Belen basin.

Plans for future work include: (1) collection of more gravity data to fill in large data gaps; (2) comparison of basement faults defined by gravity data to those within the alluvium that are expressed in the magnetic data; and (3) construction of a new model of the basin floor that uses the new gravity data, constrained by seismic-reflection interpretations and drill-hole information. 


\title{
MODIFICATION AND UPDATE OF ALBUQUERQUE BASIN GROUND-WATER-FLOW MODEL
}

\author{
Douglas P. McAda and John Michael Kernodle \\ U.S. Geological Survey, Water Resources Division, \\ 4501 Indian School Road, N.E., Suite 200, Albuquerque, NM 87110
}

Ground water from the Santa Fe Group aquifer system of the Albuquerque Basin is the main source of water for municipal, domestic, commercial, and industrial uses in the basin. About 40 percent of the population of New Mexico live within the Albuquerque Basin, an area of about 3,060 square miles. The Rio Grande, which extends the length of the basin, is the principal source of water for irrigated agriculture. Because the aquifer system is hydraulically connected to the Rio Grande and water in the river is fully appropriated, any reduction in flow of the river caused by ground-water withdrawal must be compensated by owning water rights on the river or by augmenting river flow (McAda, 1996, p. 3).

Hydrologic relations between the Rio Grande surface-water system and the Santa Fe Group aquifer system are complex because of the interaction of hydrologic boundary conditions, aquifer materials, aquifer stresses, and system responses. A recently developed ground-water-flow model of the Albuquerque Basin (Kernodle and others, 1995; Kernodle, in press) has portrayed some of the complexities of the hydrologic system and examined the effects of stresses on the river-aquifer system. This U.S. Geological Survey (USGS) model simulated ground-water flow using 11 layers, 244 rows, and 178 columns, a horizontal grid spacing ranging from 200 meters to 1 kilometer, and layer thickness ranging from about 6 to 150 meters. Sixty-one stress periods represented the 1901 to 1995 historical period.

Modifications and updates of the USGS model make it more functional for parameter-estimation and time-of-travel studies and as a management tool for water-resources administration in the basin. The modifications include a coarser finite-difference grid, a reduced number of layers, and fewer stress periods than that of the original (Mike Kernodle, USGS, written commun., March 7, 1996). As part of that effort, errors in the original model (as noted by Kernodle, in press) were corrected and more current geohydrologic interpretations of the Albuquerque Basin were incorporated. In addition, more accurate elevations were simulated for boundary features in the Rio Grande valley and several errors in reported ground-water withdrawal were corrected. The modified model uses 6 layers, 113 rows, and 60 columns, a horizontal grid spacing ranging from 750 meters to 5 kilometers, and layer thickness ranging from about 12 to 240 meters. This model uses 29 stress periods to represent 1901 to 1995 . The modified model was used to apply parameter-estimation techniques for model calibration (Tiedeman, 1997), and to compare computed travel times to water ages (Sanford and Plummer, 1997).

A cooperative project between the New Mexico Office of the State Engineer and the USGS has been initiated to update the model for use as a wateradministration tool in the basin. These updates would include information that is currently being collected on the river-aquifer system. Several investigations, many of which are described in Bartolino (1997) and in articles included in this volume, will contribute to model updates. New information on geologic framework; recharge; ground-water withdrawal; aquifer hydraulic characteristics; piezometric heads in major pumping areas and immediately below the Rio Grande; canal and drain characteristics; and changes in Rio Grande, canal, and drain flow through major pumping areas would be used to update and calibrate the model.

\section{REFERENCES}

Bartolino, J.R., (ed.), 1997, U.S. Geological Survey Middle Rio Grande Basin Study-Proceedings of the first annual workshop, Denver, Colorado, November 12-14, 1996: U.S. Geological Survey Open-File Report 97-116, 91 p.

Kernodle, J.M., in press, Simulation of ground-water flow in the Albuquerque Basin, central New Mexico, 1901-1995, with projections to 2020-Supplement two to U.S. Geological Survey Water-Resources Investigations Report 944251: U.S. Geological Survey Open-File Report 96-209. 
Kernodle, J.M., McAda, D.P., and Thorn, C.R., 1995, Simulation of ground-water flow in the Albuquerque Basin, central New Mexico, 1901-1994, with projections to 2020: U.S. Geological Survey Water-Resources Investigations Report 94-4251, 114 p., 1 pl.

McAda, D.P., 1996, Plan of study to quantify the hydrologic relations between the Rio Grande and the Santa Fe Group aquifer system near Albuquerque, central New Mexico: U.S. Geological Survey Water-Resources Investigations Report 96-4006, $58 \mathrm{p}$.

Sanford, W.E. and Plummer, L.N. 1997, Improving the Middle Rio Grande MODFLOW model using MODPATH and environmental tracers, in Bartolino, J.R., (ed.), U.S. Geological Survey Middle Rio Grande Basin Study -Proceedings of the first annual workshop, Denver, Colorado, November 12-14, 1996: U.S. Geological Survey Open-File Report 97-116, p. 39-41.

Tiedeman, C.R., 1997, Application of parameter estimation methods to the ground-water flow model of the Middle Rio Grande Basin, in Bartolino, J.R., (ed.), U.S. Geological Survey Middle Rio Grande Basin Study-Proceedings of the first annual workshop, Denver, Colorado, November 12-14, 1996: U.S. Geological Survey Open-File Report $97-$ 116, p. 42.

\title{
APPLICATION OF PARAMETER-ESTIMATION METHODS TO THE GROUND-WATER FLOW MODEL OF THE MIDDLE RIO GRANDE BASIN
}

\author{
Claire R. Tiedeman \\ U.S. Geological Survey, Water Resources Division, Branch of Regional Research, \\ 345 Middlefield Road, MS 496, Menlo Park, CA 94025
}

Parameter-estimation methods are applied to the ground-water flow model of the Middle Rio Grande Basin, with the goals of calibrating the model and comparing estimation results for four different representations of the basin subsurface. The finitedifference model to which parameter estimation is applied is based on that developed by Kernodle and others (1995), but has coarser spatial and temporal discretization. Optimal estimates are obtained by a nonlinear regression technique that adjusts parameter values such that the sum of squared weighted differences between simulated and observed hydraulic heads and flows is minimized. About 900 head measurements and one flow measurement are included in the calibration data set. The head data are from wells located throughout the basin, and were collected during the years 1949 through 1994. The flow observation is the net flow during the winter months from the Rio Grande and riverside drains to the groundwater system between the gaging stations near Bernalillo and Rio Bravo.

Major hydrologic boundary conditions in the model include mountain-front and tributary recharge, underflow from adjacent basins, evapotranspiration, and interaction of the ground-water flow system with the Rio Grande, canals, and drains. The delineation of the basin hydrogeologic units in the model is similar to that in the model of Kernodle and others (1995). In this study, however, four different representations of the subsurface are considered, and model parameters are estimated for each (Table 1). The high-K (hydraulic conductivity) zone in the west basin is included in representations 2 and 4 to test the hypothesis that there is a very permeable geologic deposit in this part of the basin that results in a "trough" in the configuration of the

Table 1. Summary of subsurface representations.

\begin{tabular}{ccc}
$\begin{array}{c}\text { Subsurface rep- } \\
\text { resentation }\end{array}$ & $\begin{array}{c}\text { Basin thickness be- } \\
\text { neath the Rio Grande } \\
(\mathrm{ft})\end{array}$ & $\begin{array}{c}\text { West-basin high-K } \\
\text { zone included? }\end{array}$ \\
\hline 1 & 1600 & No \\
2 & 1600 & Yes \\
3 & 5000 & No \\
4 & 5000 & Yes
\end{tabular}

water table. This "trough" was first inferred by Bjorklund and Maxwell (1961) and Titus (1963). Thicker basin deposits (Table 1) are included in representations 3 and 4 to investigate the effects of in- 
corporating deep ground-water flow in the simulation.

Model parameters to which the data as a whole are most sensitive are estimated by the nonlinear regression procedure, whereas the values of the remaining parameters are specified. Estimated parameters include: (1) hydraulic conductivity of the

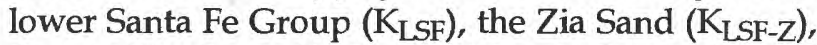
the middle Santa Fe Group ( $\mathrm{K}_{\mathrm{MSF}}$ ), the undivided upper Santa Fe Group (K $\mathrm{K}_{\mathrm{USF} 1}$ ), the undivided axial channel deposits of the upper Santa Fe Group ( $\mathrm{K}_{\mathrm{USF} 2}$ ), and the river alluvium ( $\left.\mathrm{K}_{\mathrm{RA}}\right)$; (2) recharge along the east mountains $\left(R_{\text {East }}\right)$, the Jemez River $\left(R_{\text {Jemez }}\right)$, and the Rio Puerco $\left(R_{\text {Puerco }}\right)$; and (3) the vertical anisotropy of the basin sediments $\left(A_{V}\right)$, defined as the ratio of horizontal to vertical hydraulic conductivity.

Estimation results indicate that although there are differences in fit at many observation locations, the overall match of simulated to observed hydraulic heads and flows is similar for each of the four subsurface representations. The estimates of some hydraulic conductivity parameters and of $A_{V}$, however, differ significantly among the representations (Fig. 2). All of the parameter estimates are reasonable only when the west-basin high-K zone is included in the model (representations 2 and 4). In representations 1 and 3 , the estimates of $\mathrm{K}_{\mathrm{USF} 1}, \mathrm{~K}_{\mathrm{MSF}}$, and $\mathrm{K}_{\mathrm{LSF}-\mathrm{Z}}$ are too large, and the confidence intervals on $\mathrm{K}_{\text {USF1 }}$ and $\mathrm{K}_{\mathrm{MSF}}$ lie entirely outside the reasonable ranges of values. In representations 2 and 4, which contain the west-basin high-K zone, all of the parameter estimates and the majority of each confidence interval lie within the realistic ranges. Of these two representations, however, neither is clearly preferable. The estimate of $\mathrm{K}_{\mathrm{MSF}}$ is more reasonable in representation 4 , because it is definitively smaller than the estimate of $\mathrm{K}_{\mathrm{USF} 1}$, as is likely based on information about basin depositional processes. The estimates of $K_{R A}$ and $A_{V}$ are more reasonable in representation 2 , because these estimates and their confidence intervals lie entirely within the realistic ranges; while in representation 4, the estimates are at the lower end of, and the confidence intervals extend outside of, these ranges. Although not shown, the estimates of $R_{\text {East }}, R_{\text {Jemez, }}$ and $R_{P u-}$ erco are reasonable, in that for each of the representations the estimates are between about 0.5 and 2.0 times the recharge rates calculated by Kernodle and Scott (1986) using a water-budget method.
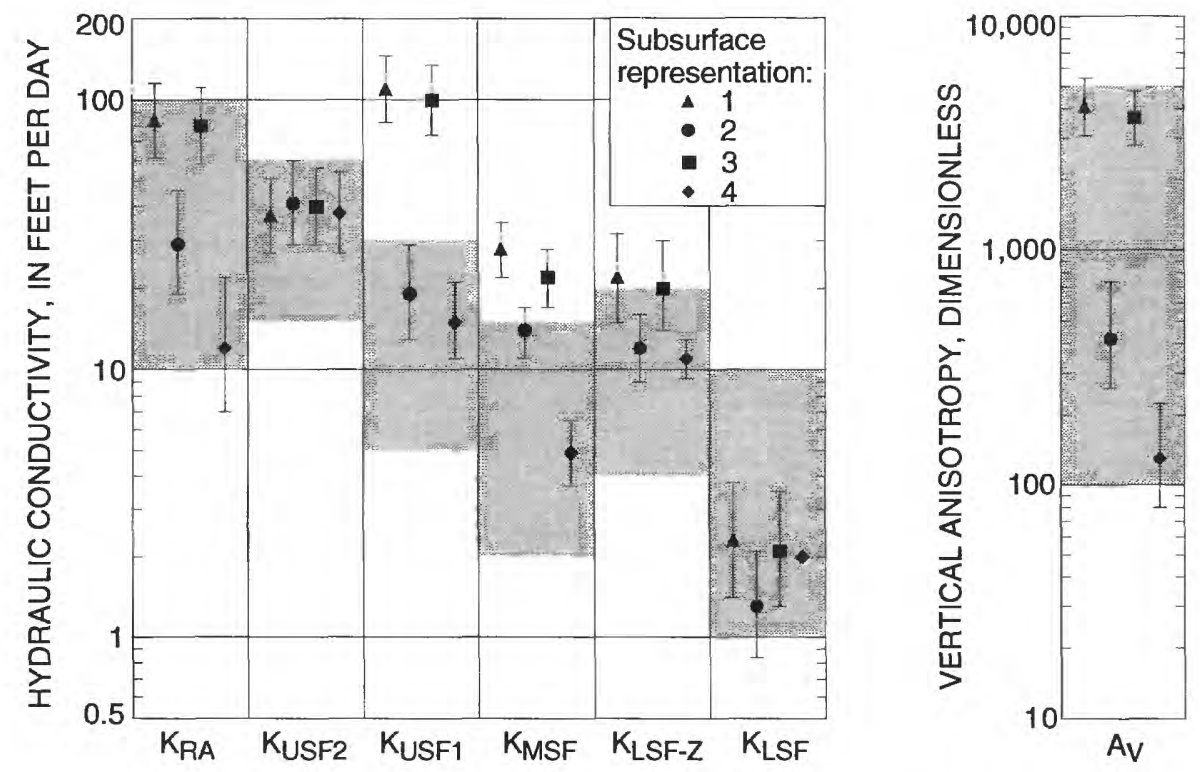

Figure 2. Optimal parameter estimates and approximate, linear 95-percent confidence intervals. Shaded regions are the reasonable range of values for each parameter. $\mathrm{K}_{\mathrm{LSF}}$ is specified as $2.0 \mathrm{ft} /$ day in representation 4 .

\section{REFERENCES}

Bjorkland, L.J., and Maxwell, B.W., 1961, Availability of ground water in the Albuquerque area, Bernalillo and Sandoval Counties, New Mexico: New Mexico State Engineer Technical Report 21, 117 p.

Kernodle, J.M., McAda, D.P., and Thorn, C.R., 1995, Simulation of ground-water flow in the Albuquerque Basin, central New Mexico, 1901-1994, with projections to 2020: U.S. Geological Survey Water-Resources Investigation Report 94-4251, $114 \mathrm{p}$. 
Kernodle, J.M., and Scott, W.B., 1986, Three-dimensional model simulation of steady-state ground-water flow in the Albuquerque-Belen Basin, New Mexico: U.S. Geological Survey Water-Resources Investigation Report 84-4353, $58 \mathrm{p}$.

Titus, F.B., Jr., 1963, Geology and ground-water conditions in Eastern Valencia County, New Mexico: Socorro: New Mexico Bureau of Mines and Mineral Resources Ground-Water Report 7, 113 p.

\title{
USING ENVIRONMENTAL TRACER DATA TO IMPROVE THE U.S. GEOLOGICAL SURVEY MODFLOW MODEL OF THE MIDDLE RIO GRANDE BASIN
}

\author{
Ward E. Sanford ${ }^{1}$, L. Niel Plummer ${ }^{1}$, and Laura M. Bexfield ${ }^{2}$ \\ ${ }^{1}$ U.S. Geological Survey, Water Resources Division, \\ 431 National Center, Reston, VA 20192 \\ ${ }^{2}$ U.S. Geological Survey, Water Resources Division, \\ 4501 Indian School Rd., N.E., Suite 200, Albuquerque, NM 87110
}

During the summers of 1996 and 1997, groundwater samples were collected from 246 locations throughout the Middle Rio Grande Basin and analyzed for environmental tracers that include CFCs, ${ }^{2} \mathrm{H},{ }^{3} \mathrm{H},{ }^{18} \mathrm{O},{ }^{13} \mathrm{C},{ }^{14} \mathrm{C},{ }^{34} \mathrm{~S}$ and $\mathrm{SF}_{6}$, as well as for majorand minor-ion chemistry. These tracers can potentially reveal information about the travel times and paths of ground water within the Middle Rio Grande Basin. Such information can prove to be even more valuable when combined with additional data such as water levels, and with information about physical parameters of the ground-water system such as recharge rates and aquifer transmissivities. Kernodle and others (1995) developed a numerical ground-water flow model of the Middle Rio Grande Basin using the U.S. Geological Survey code, MODFLOW (McDonald and Harbaugh, 1988), that included measurements and estimates of many of these physical parameters. The objective of this work is to use the recently-collected environmental tracer data to help further constrain a flow model of the basin that is based on the original model of Kernodle and others (1995). The tracer data that have been analyzed to date suggest that there is good potential for improvement of the model.

Deuterium and oxygen-18 can be useful as tracers when different sources of water give consistently different concentrations of these isotopes. Such is the case in the Albuquerque area; water from the Rio Grande has deuterium concentrations that vary consistently between -90 and $-100 \%$, yet water recharged along the eastern mountain front has concentrations that are consistently heavier (less nega- tive) than $-85 \%$. Sampling of ground water beneath the City of Albuquerque has shown that the water west of Louisiana Boulevard generally has deuterium concentrations lighter than $-90 \%$ o whereas water east of that line has values heavier than $-90 \%$. This suggests that ground water west of this line originated from the river but ground water east of the line originated from the mountains. This information, however, should be compared with water levels in the area, which are physical indicators of flow direction.

Water levels in the Albuquerque area in 1960 (Bjorklund and Maxwell, 1961) showed some drawdown because of pumping, but also displayed overall patterns that likely represented predevelopment conditions. Water-level contours from 1960 indicate that water was entering the aquifer system from the Rio Grande just north of Albuquerque near the town of Corrales and moving to the west of the river. The 1960 water-level contours also suggest that water was recharging from the river and moving south within about a five-mile zone east of the river. The water-level data are ambiguous, however, as to whether or not river water could have been moving as far east as Louisiana Boulevard (about 10 miles east the river). The deuterium and oxygen-18 data therefore may be independent confirmation that river water is entering the aquifer system under natural conditions and moving southeastward as far as 10 miles east of the river before moving in a southwesterly direction back toward the river. It is unlikely that this effect is due to pumping because ground waters beneath the east- 
ern section of the city all have preliminary ${ }^{14} \mathrm{C}$-based ages of several thousand years. The results of flowmodel simulations (Kernodle and others, 1995) are inconsistent with this observation of significant natural recharge from the river, in that they indicate no recharge should occur from the river under natural conditions.

In order to better understand how river water might enter the aquifer system under natural conditions and why the results of Kernodle and others (1995) might be inconsistent with the environmental tracer data, we constructed a new, simplified model for purposes of conducting a sensitivity analysis. A box-shaped model was made to the dimensions of the central part of the basin ( 25 miles by 50 miles by 3000 feet thick) and a river was located on the topcenter column of cells with a gradient similar to that of the Rio Grande. Values of hydraulic conductivity, mountain-front recharge, and anisotropy were then varied to see under what conditions some river water might take a substantial diversion through the aquifer system. For values of recharge and conductivity similar to the 1995 model, the simple model produced the same results as the original model - the Rio Grande gains water over its entire course. With less mountain recharge (or higher transmissivities), however, the simple model showed that some river water diverts through the aquifer system in a pattern that is very similar to that observed in the Albuquerque area. This suggests that specified recharge values in the 1995 model are too high (or that conductivity values are too low).

The fact that recharge and transmissivities can affect the extent to which river water may be entering the aquifer system implies that the deuterium data could be used in a more direct way to help calibrate an improved model of the basin. Plans are now underway for the use of a general nonlinear regression model, such as UCODE (Poeter and Hill, in review) or PEST (Doherty, 1994), in combination with MODFLOW and MODPATH (Pollock, 1994) in order to use the environmental tracer data to calibrate the model. Carbon-14-based ages will add additional independent information that will be used in the calibration procedure. Calibrations with deuterium and ${ }^{14} \mathrm{C}$ data will be done originally assuming steady-state flow conditions. Transient calibrations can then be performed for the last 50 years to include drawdown data, and for the last 30,000 years to include possible changes in recharge through the end of the last ice age. Other modifications to the original model are planned, including some grid refinement and the addition of some lower layers and zones that will make the model more consistent with the latest geologic information.

\section{REFERENCES}

Bjorklund, L.J., and Maxwell, B.W., 1961, Availability of ground water in the Albuquerque area, Bernalillo and Sandoval Counties, New Mexico: New Mexico State Engineer Technical Report 21, 117 p.

Doherty, J., 1994, PEST: Corinda, Australia; Watermark Computing, 122 p.

Kernodle, J.M., McAda, D.P., and Thorn, C.R., 1995, Simulation of ground-water flow in the Albuquerque basin, Central New Mexico, 1901-1994, with projections to 2020: U.S. Geological Survey Water-Resources Investigations Report 94-4251, 114 p.

McDonald, M.G., and Harbaugh, A.W., 1988, A modular three-dimensional finite-difference ground-water flow model: U.S. Geological Survey Techniques of Water-Resources Investigations, Book 6, Chapter A1, variously paged.

Poeter, E.P., and Hill, M.C., 1998, Documentation of UCODE, a computer code for universal inverse modeling: U.S. Geological Survey Water-Resources Investigations Report 98-4080, 120 p.

Pollock, D.W., 1994, User's guide for MODPATH/MODPATH-PLOT, Version 3: A particle tracking post-processing package for MODFLOW, the U.S. Geological Survey finite-difference ground-water flow model: U.S. Geological Survey Open-File Report 94-464, variously paged. 


\title{
TRACING AND DATING GROUND WATER \\ IN THE MIDDLE RIO GRANDE BASIN, NEW MEXICO-A PROGRESS REPORT
}

\author{
L. Niel Plummer', Ward E. Sanford ${ }^{1}$, Eurybiades Busenberg ${ }^{1}$, \\ Laura M. Bexfield ${ }^{2}$, Scott K. Anderholm ${ }^{2}$, and Peter Schlosser ${ }^{3}$ \\ ${ }^{1}$ U.S. Geological Survey, Water Resources Division, \\ 432 National Center, Reston, VA 20192 \\ ${ }^{2}$ U.S. Geological Survey, Water Resources Division, \\ 4501 Indian School Rd., N.E., Suite 200, Albuquerque, NM 87110 \\ ${ }^{3}$ Lamont-Doherty Earth Observatory of Columbia University, Palisades, NY 10964
}

Concentrations of environmental tracers and other chemical and isotopic substances are being determined in ground water from the Santa Fe Group aquifer in the vicinity of Albuquerque, New Mexico, and regionally throughout the Middle Rio Grande Basin. The analyses include major- and minorelement chemistry, tritium $\left({ }^{3} \mathrm{H}\right)$, tritiogenic helium-3 ( $\left.{ }^{3} \mathrm{He}\right)$, chlorofluorocarbons (CFCs: CFC-11, CFC-12, CFC-113), sulfur hexafluoride $\left(\mathrm{SF}_{6}\right)$, oxygen-18 $\left({ }^{18} \mathrm{O}\right)$ and deuterium $\left({ }^{2} \mathrm{H}\right)$ in water, carbon- $13\left({ }^{13} \mathrm{C}\right)$ and carbon-14 $\left({ }^{14} \mathrm{C}\right)$ of dissolved inorganic carbon (DIC), and other dissolved gases (including dissolved oxygen, nitrogen, argon, helium, neon, and carbon dioxide). These data are being used to: (1) identify recharge areas; (2) date the young (0- to $50-\mathrm{yr})$ and old (>2000-yr) water in the aquifer; (3) trace movement of ground water throughout the Basin; (4) estimate recharge rates; (5) trace Rio Grande river water and water from the drain and canal system that has entered the Santa Fe Group aquifer in the Albuquerque area; and (6) help refine the groundwater flow model (Kernodle and others, 1995) developed for the Albuquerque Basin.

Since June 1996, we collected 246 ground-water samples from available sources including municipal, domestic, and monitoring wells, springs, and windmills. In addition to the more complete ground-water sampling, monthly sampling of the Rio Grande and adjacent drains and laterals, and water from Tijeras Arroyo and Bear Canyon was initiated in January 1997 for CFCs, stable isotopes, tritium, and major- and minor-element chemistry. Samples of air and unsaturated-zone gas are being analyzed quarterly for $\mathrm{CFCs}, \mathrm{SF}_{6}$, and ${ }^{13} \mathrm{C}$ of $\mathrm{CO}_{2}$ gas. Ground-water samples collected at all available City of Albuquerque production wells in the summer of 1997 have been analyzed for stable isotopes. Archived ground-water samples from City of Albuquerque production wells, water from the Rio Grande, and precipitation from the 1980s have also been analyzed for stable isotopes. To date, all chemical analyses of the ground-water samples are complete for major- and minor-element composition, dissolved gases, CFCs, stable isotopes, and $\mathrm{SF}_{6}$. Carbon-14 has been determined on 101 groundwater DIC samples and an additional 80 samples are currently being analyzed. Tritium/helium-3 $\left({ }^{3} \mathrm{H} /{ }^{3} \mathrm{He}\right)$ analyses have been completed for 35 water samples collected in June 1996. ${ }^{3} \mathrm{H} /{ }^{3} \mathrm{He}$ data will be obtained on approximately 100 water samples.

The project is near the end of the data-acquisition phase. Additional samples will be collected in summer 1998 at all deep-monitoring nests completed since July 1997, and additional water samples will be collected in selected parts of the Basin. Although the results are still preliminary, we can make some general observations.

The tritium concentration in 20 water samples from the Rio Grande averaged $8.4 \pm 0.7( \pm 1 \sigma)$ TU (tritium units). CFC-11, CFC-12, and CFC-113 concentrations in 104 samples of surface water from the Rio Grande and adjacent drains and laterals averaged $109 \pm 28,149 \pm 74$, and $112 \pm 19( \pm 1 \sigma)$ percent of the respective air-water-saturation value, after correction for seasonal temperature variations.

CFC-12 concentrations averaged $30 \pm 111( \pm 1 \sigma)$ picograms per kilogram $(\mathrm{pg} / \mathrm{kg})$ in 45 ground-water samples from undeveloped areas basin-wide, and were typically at or below the detection limit of 0.3 $\mathrm{pg} / \mathrm{kg}$ in many of the waters from rural areas. In developed areas within and surrounding the City of Albuquerque, the mean and standard deviation for CFC-12 concentrations in 98 ground-water samples were $2300 \pm 9400( \pm 1 \sigma) \mathrm{pg} / \mathrm{kg}$. In many cases, the CFC concentrations were orders of magnitude greater than that possible for water in equilibrium with modern air. Under the eastern third of the City of Albuquerque up to the adjacent mountain 
front, CFC-12 concentrations in most ground-water samples were below detection. In contrast, CFC-12 was commonly detected in water pumped from wells open to large intervals of the aquifer located beneath the western two-thirds of the City of Albuquerque, extending eastward from the Rio Grande. Analyses of ground-water samples from discrete depths in the inner valley (floodplain) of the Rio Grande show high concentrations of CFC-12 at shallow depths.

Tritium concentrations were less than $0.1 \mathrm{TU}$ in most ground water throughout the area beneath the City of Albuquerque, except in the inner valley of the Rio Grande, where tritium concentrations were typically 9 to 25 tritium units.

The stable isotopes of water provide a useful tracer of water sources within the Basin. Delta- ${ }^{2} \mathrm{H}$ averages $-84.4 \%$ in 282 ground-water samples, with a range of -53 to $-118 \%$. Some isotopically depleted water $\left(-118\right.$ to $-105 \%$ o in $\left.\Delta^{2} \mathrm{H}\right)$ is present in wells near Rio Rancho, at a production well on the West Mesa, west of Albuquerque, and at depths of about 300 to $700 \mathrm{ft}$ below the water table at the $98^{\text {th }}$ Street and Mesa Del Sol piezometer nests, southwest of Albuquerque. Isotopically enriched water from the eastern mountain front and Tijeras Arroyo (-70 to $80 \%$ in $\Delta^{2} \mathrm{H}$ ) appears to flow south beneath parts of Kirtland Air Force Base. The most enriched waters $\left(-65\right.$ to $-53 \%$ in $\left.\Delta^{2} \mathrm{H}\right)$ are present in the southern third of the Basin.

Carbon-14 activity of DIC ranges from 123.1 to $3.0 \%$ modern carbon in 101 samples, averaging $47.2 \mathrm{pmc}$ (percent modern carbon). The unadjusted ${ }^{14} \mathrm{C}$ ages of DIC in the Albuquerque area are approximately 5000 years. ${ }^{14} \mathrm{C}$ activities are near $100 \mathrm{pmc}$ in DIC of Rio Grande water, and greater than $100 \mathrm{pmc}$ in shallow ground water in parts of the inner valley, and in some shallow wells in the eastern mountain front. The ${ }^{14} \mathrm{C}$ data indicate that water pumped from production wells in the inner valley produce mixtures of modern river water and older resident ground water of the Santa Fe Group aquifer.
Tritium/helium-3 dating of young ground water, and of the young fraction in mixtures of young and old water, is possible for some waters in the inner valley, waters along the mountain front, and shallow ground water in the vicinity of Tijeras Arroyo. Of the $92{ }^{3} \mathrm{H} /{ }^{3} \mathrm{He}$ samples submitted for analysis from the summer 1996 sampling, 53 have been analyzed, and of these, 20 samples have apparently reliable ages, ranging from 0.3 to more than 30 years. For many of the waters from outside the inner valley and outside areas of modern recharge, ${ }^{3} \mathrm{H}$ concentrations are extremely low due to groundwater ages greater than 50 years, dilution with old water, and/or low recharge rates. Furthermore, many of these waters contain a large excess helium component. For these waters, the fraction of young water in the mixture cannot be dated using the ${ }^{3} \mathrm{H} /{ }^{3} \mathrm{He}$ method.

CFC-12 may be useful in dating some recharge waters in the inner valley, near Tijeras Arroyo, and along the mountain front. Using recharge temperatures based on measurements of dissolved nitrogen and argon, and estimated recharge elevations, the mountain-front waters sampled were probably recharged within the past 30 years. For example, water from Hubbell Spring on the Hubbell Bench south of Albuquerque appears to be about 23 years old. Water from a closely-spaced piezometer nest in the Duranes well-field near the Rio Grande has a well-defined age gradient based on CFC-12, that indicates a vertical component of ground-water velocity of approximately $2.8 \mathrm{ft} / \mathrm{yr}$.

CFC-12 dating is often complicated in the Albuquerque area. Local sources of contamination lead to apparently young or impossible ages. Dilution with older CFC-free water pumped from wells with large open intervals result in apparent ages that are too old. At this preliminary stage of analysis, many more waters may be dated with $\mathrm{CFC}-12$ and ${ }^{3} \mathrm{H} /{ }^{3} \mathrm{He}$, but presently there are only five waters codated with ${ }^{3} \mathrm{H} /{ }^{3} \mathrm{He}$ and $\mathrm{CFC}-12$ for which the apparent ages agree within 2 years.

\section{REFERENCE}

Kernodle, J.M., McAda, D.P., and Thorn, C.R., 1995, Simulation of ground-water flow in the Albuquerque Basin, central New Mexico, 1901-1994, with projections to 2020: U.S. Geological Survey Water-Resources Investigations Report 94-4251, 114p. 


\title{
GEOLOGY OF THE COCHITI PUEBLO AREA AND THE CERRILLOS UPLIFT BASED ON GEOLOGIC MAPPING, AIRBORNE AND GROUND GEOPHYSICS, AND LIMITED SUBSURFACE INFORMATION
}

\author{
David Sawyer ${ }^{1}$, Maria Deszcz-Pan², V.J.S. Grauch ${ }^{2}$, Gary Smith ${ }^{3}$, David Dethier ${ }^{4}$, \\ Ren Thompson ${ }^{1}$, Scott Minor ${ }^{1}$, Ralph Shroba ${ }^{1}$, Brian Rodriguez ${ }^{2}$, and Andrika Kuhle ${ }^{3}$ \\ ${ }^{1}$ U.S. Geological Survey, National Cooperative Geologic Mapping, \\ Box 25046, MS 913, Denver, CO 80225 \\ ${ }^{2}$ U.S. Geological Survey, Mineral Resources, \\ Box 25046, MS 964, Denver, CO 80225 \\ ${ }^{3}$ Department of Earth and Planetary Sciences, University of New Mexico, \\ Albuquerque, NM 87131 \\ ${ }^{4}$ Department of Geology, Williams College, Williamstown, MA 01267
}

Geologic mapping and geophysical investigations in the Cochiti Pueblo area provide a better understanding of the geologic framework and hydrogeology in this area southwest of Santa Fe. This information is critical to improving models for groundwater underflow from both the Española basin and Pajarito Plateau to the north, into aquifers of the larger Albuquerque ground-water system to the south. Our new investigations, combined with limited subsurface information from 20 water wells, provide new insights regarding the Santo Domingo basin, which forms the critical hydrologic link between the Española and Albuquerque basins.

Geologic mapping in the Cochiti Pueblo area provides stratigraphic, structural and age constraints for lithologic units relevant to the regional hydrogeologic framework of the Santo Domingo basin. Natural outcrops rarely expose surface units for more than a few tens to a hundred meters depth. Surface knowledge of these stratigraphic units and offsets along faults, however, allow extrapolation of subsurface data from wells, and airborne and surface geophysics across much larger areas. The principal geologic units mapped at the surface in the Cochiti Pueblo area are: (1) unconsolidated Pleistocene surficial deposits of gravel, sand, silt, and clay; (2) two Pleistocene rhyolite ash-flow tuff members of Bandelier Tuff erupted from the Valles caldera; (3) basalt and andesite of the Pliocene Cerros del Rio volcanic field; (4) rift-filling piedmont and axial Rio Grande sedimentary deposits of the Santa Fe Group, extending in age from at least Middle Miocene into the Pleistocene; (5) Miocene rhyolite, andesite, and basalt, specifically the Bearhead Rhyolite domes, lava, and Peralta tuff; (6) pre-rift Eocene-Oligocene sedimentary, volcanic, and plutonic rocks; (7) Cretaceous sedimentary units deposited in the Western Interior Seaway; and (8) Triassic-Jurassic units similar to those of the Colorado Plateau.

A combined airborne geophysical survey using separate time-domain electromagnetic pulse (TDEM) and aeromagnetic sensors was flown in March 1997 near Cochiti Pueblo. The $15 \times 20-\mathrm{km}$ survey consists of lines with a $400-\mathrm{m}$ flight spacing approximately $120 \mathrm{~m}$ above ground level. Preliminary plan maps of TDEM voltages, recorded at different times, show that TDEM response generally corresponds to grain size of clastic alluvial sedimentary deposits. These results allow us to identify several distinct domains in the Cochiti Pueblo area based on different TDEM responses. The northern limit of the Mancos Shale (a strong conductor) is distinctive in the subsurface north of the Santa $\mathrm{Fe}$ River canyon, where it is truncated by an ENEtrending structural zone roughly on trend with projection of the Santa Fe River fault zone. We interpret more resistive units north of this boundary to reflect a thickening of both Cerros del Rio basalts and Santa Fe Group sediments. The TDEM data west of the La Bajada fault zone show that relatively lower resistivity values correspond to Santa Fe Group piedmont deposits or to Cochiti Formation volcaniclastic sediments, whereas relatively higher resistivity values correspond to axial gravel deposits of the ancestral Rio Grande. To provide independent calibration for the airborne electromagnetic sur- 
vey, we collected six audiomagnetotelluric (AMT) stations that show a good correlation with lithologic information from wells and geologic mapping.

Aeromagnetic features in the new Cochiti airborne survey include the basaltic Cerros del Rio volcanic field; silicic volcanic units of the Jemez volcanic field (especially the Bandelier Tuff and Bearhead Rhyolite); and sedimentary fill of the Santo Domingo basin, including intercalated and faulted basalts. A prominent break in the aeromagnetic pattern parallels the La Bajada fault zone. Numerous high-amplitude positive and reversed magnetic anomalies correspond to the many vents and complex stratigraphy of the Cerros del Rio volcanic field. The western half of the survey contains moderate- to low-intensity anomalies that correspond to units within the Santa Fe Group sedimentary fill overlain by reversely magnetized Bandelier Tuff, and faults that offset these strata. Between the Rio Grande and the La Bajada fault system, a prominent magnetic low parallels the La Bajada fault, and local positive magnetic anomalies indicate basaltic vents buried beneath the surface of the adjacent La Majada geomorphic surface.

Gravity data (from existing compilations by Cordell and Keller, supplemented by more recent SAGE data in Ferguson and others, 1995) show a strong positive anomaly on the eastern flank of the Rio Grande rift that has been termed the Cerrillos uplift. Contrary to previous models, the NW limit of the
Cerrillos uplift does not extend beneath the Cerros del Rio volcanic field to the prominent St. Peters Dome basement high on the western side of the Española Basin. We interpret the gravity data and geologic map relations to indicate there was no structural boundary between the southern Española basin and the Santo Domingo basin prior to eruption of the 2.7-2.3 Ma Cerros del Rio volcanic field. The basin geometry of the Miocene-Pliocene Rio Grande rift therefore deviates from that of the modern geomorphic Rio Grande valley in the area of the poorly defined northeast Santo Domingo basin. Although late Pliocene to early Pleistocene offset of as much as $375 \mathrm{~m}$ separates the Cerros del Rio basalts across the La Bajada fault zone, the minimum structural relief from the Cerrillos uplift to the axis of the southern Española and northern Santo Domingo basins is significantly greater. We believe these relations show that maximum subsidence in this part of the Rio Grande rift, adjacent to the Cerrillos uplift, occurred during Miocene through middle Pliocene time before eruption of the Cerros del Rio volcanic field.

Acknowledgments: We gratefully acknowledge permission to work on Cochiti Pueblo given by Governors of Cochiti Pueblo, the cooperation of the staff of the Cochiti Environmental Protection Office (CEPO), and the encouragement of Don Diego Gonzalez.

\section{REFERENCE}

Ferguson, John F., Baldridge, W.S., Braile, L.W., Biehler, S., Gilpin, B., and Jiracek, G.R., 1995, Structure of the Española basin, Rio Grande rift, from SAGE seismic and gravity data: New Mexico Geological Society Guidebook, $46^{\text {th }}$ Field Conference, Geology of the Santa Fe Region, p. 105-110. 


\title{
HYDROGEOLOGIC AND TECTONIC SIGNIFICANCE OF NEW GEOLOGICAL MAPPING IN THE SANTO DOMINGO BASIN AND ADJACENT JEMEZ MOUNTAINS
}

\author{
Gary A. Smith ${ }^{1}$, Andrika J. Kuhle ${ }^{1}$, and William C. McIntosh ${ }^{2}$ \\ ${ }^{1}$ Department of Earth and Planetary Sciences, University of New Mexico, Albuquerque, NM 87131 \\ ${ }^{2}$ New Mexico Bureau of Mines and Mineral Resources, \\ 801 Leroy Place, Socorro, NM 87801
}

Geological mapping at 1:24,000 scale on the Santo Domingo Pueblo, Santo Domingo Pueblo SW, Cañada, and Cochiti Dam 7.5' quadrangles, complemented by ${ }^{40} \mathrm{Ar} /{ }^{39} \mathrm{Ar}$ geochronology, has led to refinement and revision of stratigraphic and structural characteristics of the northern Santo Domingo Basin and the margin of the Jemez Mountains volcanic field.

A greater proportion of coarse, gravelly sediment is present in this region than was appreciated during construction of the Kernodle et al. (1995) groundwater-flow model for the Albuquerque basin and suggests the need for upward revision of hydraulic conductivities for most model cells by an order of magnitude (to $\sim 10^{-2} \mathrm{~cm} / \mathrm{s}$ ). Ancestral Rio Grande gravel and sand are widespread within the upper Santa Fe Group, extending as much as $12 \mathrm{~km}$ west of, and at least $5 \mathrm{~km}$ east of, the modern river. West of Cochiti Pueblo, these strata are intercalated with $\sim 6.8$ Ma pyroclastic deposits of the Peralta Tuff Member of the Bearhead Rhyolite and underlie a $\sim 6.96 \mathrm{Ma}$ rhyolite dome. Rather than being a thin Plio-Pleistocene capping layer, as depicted on previous maps, this facies is at least $500 \mathrm{~m}$ thick, thus occupying a substantial volume of the shallow saturated zone, and indicates the presence of a gravelbedload axial stream at an earlier time than previously maintained by most workers. West of the Rio Grande, the axial facies interfingers with Peralta Tuff and uppermost Miocene-lower Pleistocene Cochiti Formation. The Peralta Tuff consists of poorly consolidated, well to poorly sorted rhyolitic tuff and lapilli tuff intimately intermingled with poorly sorted sandy gravel dominated by vitric-rhyolite clasts. Near fault zones, stratiform chalcedony (and less common calcite) cementation is prevalent and reaction of groundwater with volcanic glass may have caused substantial cementation below the water table. The Cochiti Formation, following usage of Smith and Lavine (1996), is an at least 500-m-thick sequence of gravel and sand that is at the surface over most of western Cochiti and Santo Domingo Pueblos. Gravel dominates in northern and western outcrops and cementation is generally minor except locally near faults. These coarse strata of the Cochiti Formation are also likely more hydraulically conductive than realized in the Kernodle model, potentially leading to new views of recharge routing from the Jemez Mountains.

The Santo Domingo Basin comprises the accommodation zone between oppositely tilted Española and Albuquerque basins. Normal faults at the margins and within the Santo Domingo Basin face both east and west to form a nearly symmetrical graben. Down-to-the-east faults increase in displacement northward where they eventually form the western, stepped margin of the Española basin half-graben. Faults with the opposite displacement sense increase in offset southward into the asymmetrically east-tilted northern Albuquerque basin. Intrabasinal faults strike NNW at a low angle to the N-S strike of rift-margin structures and may reflect the extension direction across the diffuse accommodation zone. "See-saw" subsidence within the Santo Domingo basin is suggested by westward deflection of the Rio Grande during the late Miocene and subsequent eastward tilting during the Plio-Pleistocene. Youngest basin-fill sediment (intercalated with 1.84-1.87 Ma pumice correlated to the San Diego Canyon ignimbrites, and with $1.61 \mathrm{Ma}$ Otowi Member of the Bandelier Tuff) are restricted to the eastern basin. Partly correlative Pliocene gravel caps a broad erosion surface whose formation beveled older strata in the western basin during the period of eastward tilting. A return to westward tilting in the northern basin is inferred by prolonged westward migration of the Rio Grande over the past $\sim 300,000$ years.

Intrabasinal faults, of greater number, length and displacement than represented on previous maps, may partition the aquifer at depth, accounting for water levels in the western basin that are lower than the Rio Grande. Preferential calcite or chalcedony cementation along faults is obvious at many locations and may be more prevalent at depth. A horst 
trends obliquely across the basin from NW to SE near Sile and exposes upper Miocene axial gravel with abundant Peralta Tuff pumice; axial facies may not be abundant below the water table in this area. We hypothesize that the trough in the water table west of the Rio Grande is caused by the presence there of a highly transmissive section, including axial-facies gravel, that conducts Jemez Mountains recharge southward while being structurally isolated from recharge by the Rio Grande.

Faults in the southeastern Jemez Mountains are northward continuations of NNW-trending intrabasinal faults and also northeast-striking structures, not seen farther south, that presumably represent reactivated Proterozoic fabric. The Jemez lineament, therefore, appears to be a broad zone whose southeastern margin coincides almost exactly with southeastern volcanic front of the Jemez Mountains volcanic field. Nearly rectilinear blocks defined by
NE and NNW striking faults are superimposed on an overall west-tilted structural domain in the southern Jemez Mountains. The most prominent of these downfaulted blocks, which we name the Bearhead basin, subsided during accumulation of a nearly 700-m-thick section of 6-7 Ma Miocene lava, tuff, and sediment within the southern part of the field. Bearhead Rhyolite volcanism was clearly focused along the NE and NNW striking faults, and especially at their intersections, with the most voluminous extrusion occurring along the west side of the Bearhead basin. Hypabyssal intrusions of the Bland Mining District, including roof pendants of pre-Jemez sediment (lower Santa Fe Group or Galisteo Formation), are strongly uplifted in the footwall of a prominent NE-striking fault, hence explaining this area of rocks within the volcanic field that are exposed at anomalously low structural level.

\section{REFERENCES}

Kernodle, J.M., McAda, D.P., and Thorn, C.R., 1995, Simulation of ground-water flow in the Albuquerque Basin, central New Mexico, 1901-1994, with projections to 2000: U.S. Geological Survey Water-Resources Investigation Report 94-4251, $114 \mathrm{p}$.

Smith, G.A., and Lavine, A., 1996, What is the Cochiti Formation? New Mexico Geological Society, Guidebook 47, p. 219-224. 


\title{
GEOLOGIC MAPS OF THE OJITO SPRINGS, SAN YSIDRO, SKY VILLAGE NE, AND JEMEZ PUEBLO 7.5-MINUTE QUADRANGLES: RESULTS OF EDMAP AND STATEMAP EFFORTS IN THE NORTHWESTERN CORNER OF THE ALBUQUERQUE BASIN
}

\author{
F.J. Pazzaglia, M.L. Formento-Trigilio, J.L. Pederson, A.F. Garcia, D.J. Koning, and C. Toya \\ Department of Earth and Planetary Sciences, University of New Mexico,
}

Albuquerque, NM 87131-1116

We mapped a series of connected quadrangles (Ojito Springs, San Ysidro, Sky Village NE, and Jemez Pueblo) applying current lithostratigraphic nomenclature of Paleozoic, Mesozoic, and early Cenozoic rocks. We use our mapping to help redefine Santa Fe Group stratigraphy. We identified numerous new faults, some of which have demonstrable Quaternary offset, and made detailed descriptions of Quaternary deposits and landforms.

The northwestern corner of the Albuquerque basin occupies a strategic hydrologic location as groundwater recharge from the San Juan basin, Sierra Nacimiento, and Jemez Mountains is focused to the south and east along the Jemez River corridor. The structural juxtaposition of the southern Rocky Mountains (Sierra Nacimiento), Basin and Range (Rio Grande rift), Colorado Plateau, and Jemez Lineament enables us to investigate the role that diverse structures and rocks have on regional surface and ground-water hydrology. Numerous north- and northeast-striking normal faults that define the northwestern boundary of the Rio Grande rift separate Mesozoic rocks of the Colorado Plateau from the west (Ojito Springs) to the east (Jemez Pueblo). These predominantly dip-slip faults, which have locally reactivated older Laramide structures, have both down-to-the-east and downto-the-west offset, resulting in several distinct horst and graben. Commonly an individual normal-fault segment with down-to-the-west offset changes to a down-to-the-east, normal-fault segment across a short $(<0.5 \mathrm{~km})$ distance marked by a left-stepping, horst-block segment boundary. Primarily in the Jemez Pueblo quad, offset stream channels characterize such left steps. Where the faults cut basin fill, they are expressed as both carbonate-cemented resistant topographic spines and erodible clay-rich gouge valleys. The variable degree of cementation and associated rock fracturing indicate that faults can act both as barriers as well as conduits for ground-water flow.
We map several lithostratigraphic units within the Santa Fe Group. The Zia Formation (300 $\mathrm{m}$ thick) is the basal unit of the Santa Fe Group. The Zia is composed of the lower Piedra Parada Member, a white, yellow and tan eolian and fluvial sub-arkosic sand and silt, and an upper Chamisa Mesa Member composed primarily of red, yellow, and white fluvial and playa facies. Locally, the Piedra Parada Member unconformably overlies a ventifactmantled, Oligocene(?) pediment cut across Early Cenozoic and older rocks. The Zia Formation is conformably overlain by the middle Santa Fe Formation ( $\sim 600 \mathrm{~m}$ thick), a tan and yellow, predominantly fluvial sand with a distinct increase in pebble and cobble content. Coarse tan and buff-colored fluvial sands and gravel of the upper Santa Fe Formation (approximately 100-200 m thick) conformably overlie the middle Santa Fe Formation. These coarse-grained deposits include units formerly mapped as Ceja gravel and Cochiti Formation.

Numerous Quaternary deposits document postSanta Fe Group incision, and can be used to help reconstruct the genesis of modern surface drainage. For example, Jemez River deposits are rich in felsic volcanic and Paleozoic rocks, and are thus petrographically distinct from basalt-rich piedmont deposits.

Our mapping has identified a paleo-Jemez River that existed several kilometers to the north and east of its present location immediately following eruption of the upper Bandelier tephra. The progressive sweep of the river to the south and west has both lowered base level and brought it closer to the margin of the Colorado Plateau. This has likely played an important role in the recent dissection of basinfill sediments and the concomitant southward retreat of La Ceja, the north-facing Zia escarpment in the Sky Village NE quad. 


\title{
CHARACTERIZING FAULTS IN THE MIDDLE RIO GRANDE BASIN: RESULTS FROM THE COCHITI AND SANTO DOMINGO PUEBLOS
}

\author{
Scott A. Minor and Nancy A. Shock \\ U.S. Geological Survey, National Cooperative Geologic Mapping, \\ Box 25046, MS 913, Denver, CO 80225 \\ <sminor@usgs.gov>
}

Hydrologic data indicate that faults can strongly influence ground-water flow within the Middle Rio Grande Basin (MRGB) aquifer. Such data suggest that some faults have low hydraulic conductivity and act as barriers to ground-water flow (Kernodle and others, 1995). These data are too sparse, however, to determine the lateral extent of impedimentary faults, and they do not preclude that faults can act as flow conduits. Geologic studies in the MRGB and in other extensional aquifer basins indicate that ground water has flowed, or is flowing, preferentially along faults under favorable physical conditions, sometimes episodically during seismic cycles (e.g., Sibson, 1990; Mozley and Goodwin, 1995; Hickman and others, 1997). Thus, both temporal and spatial variability of fault hydrologic characteristics is expected in the MRGB. To study spatial hydrologic variability of faults in the MRGB, we have initiated a basin-wide survey to systematically measure and document a variety of physical parameters of faults at individual outcrop exposures.

Observations made at exposures of map-scale faults include: (1) fault-plane strike and dip; (2) rake of slickenside striae; (3) slip sense and chronology; (4) fault offset; (5) fault-zone fracture geometry (including foot- and hanging-wall damage zones); (6) fault-core fabric and composition; (7) fault-zone cement distribution, composition, and thickness; (8) core and damage-zone widths; (9) footwall and hanging-wall map units/lithology; (10) wall-rock bedding attitude(s); and (11) cross-cutting relations of intersecting faults. Additionally, the ratio of damage-zone width to total fault-zone width $(F a)$ is computed where determinable because this ratio may indicate fault-zone permeability (Caine and others, 1996). A narrower range of measurements is also collected from smaller (mesoscale) faults that are both adjacent to and isolated from the mapped faults. Mapping of fault zones, beyond that done by other project geologists (mainly at 1:24,000 scale), includes delineating the lateral extents of prominent fault-zone cements.
These fault data are digitized and added to the composite geologic map database in ARC/INFO GIS. Selected fault point data embedded in the GIS database are used to help delineate several types of fault line attributes, such as cemented fault-zone segments. Using field constraints, the fault attributes are extrapolated as far as about $4 \mathrm{~km}$ from the observation points along contiguous fault-line segments. The resulting multiple, overlapping, faultline attributes are defined topologically in ARC/INFO using the "dynamic segmentation" functionality. Dynamic segmentation allows for creating, editing, querying, and displaying multiple sets of attributes for linear features such as fault lines, and it permits directional routing along such features (e.g., ground-water flow paths).

Our survey results show the potential utility of fault-characterization data to provide qualitative and semi-quantitative geologic constraints for ground-water flow models in the MRGB. In the Cochiti-Santo Domingo Pueblos area, fault characterization provides information needed for accurately modeling fault controls on ground-water flow where water enters the Santo Domingo sub-basin aquifer at the northern end of the MRGB. Faults in the study area are mostly NNW-striking normal faults that dip mainly to the west on the east side of the study area, to the east on the west side, and both directions in between (Smith and Kuhle, 1997; G.A. Smith, D.P. Dethier, D.A. Sawyer, S.A. Minor, R.A. Thompson, A.J. Kuhle, and R.R. Shroba, unpub. mapping, 1997). The faults typically dip $50^{\circ}-70^{\circ}$ and have slickenside striae with moderate- to high-angle $\left(70^{\circ}-90^{\circ}\right)$ southerly rakes. Mapped fault zones, which commonly consist of a central, highlysheared core enveloped by disrupted mixed zones and outer, fractured damage zones, range in width from $<1 \mathrm{~m}$ to as much as $30 \mathrm{~m}$ (Fig. 3). Fa values computed for about $\mathbf{2 0}$ mapped faults in the survey area are all $>0.75$ and most are $>0.9$. Such relatively wide damage zones suggest that the bulk fault zones in this area may act more like ground-water conduits than previously assumed. 


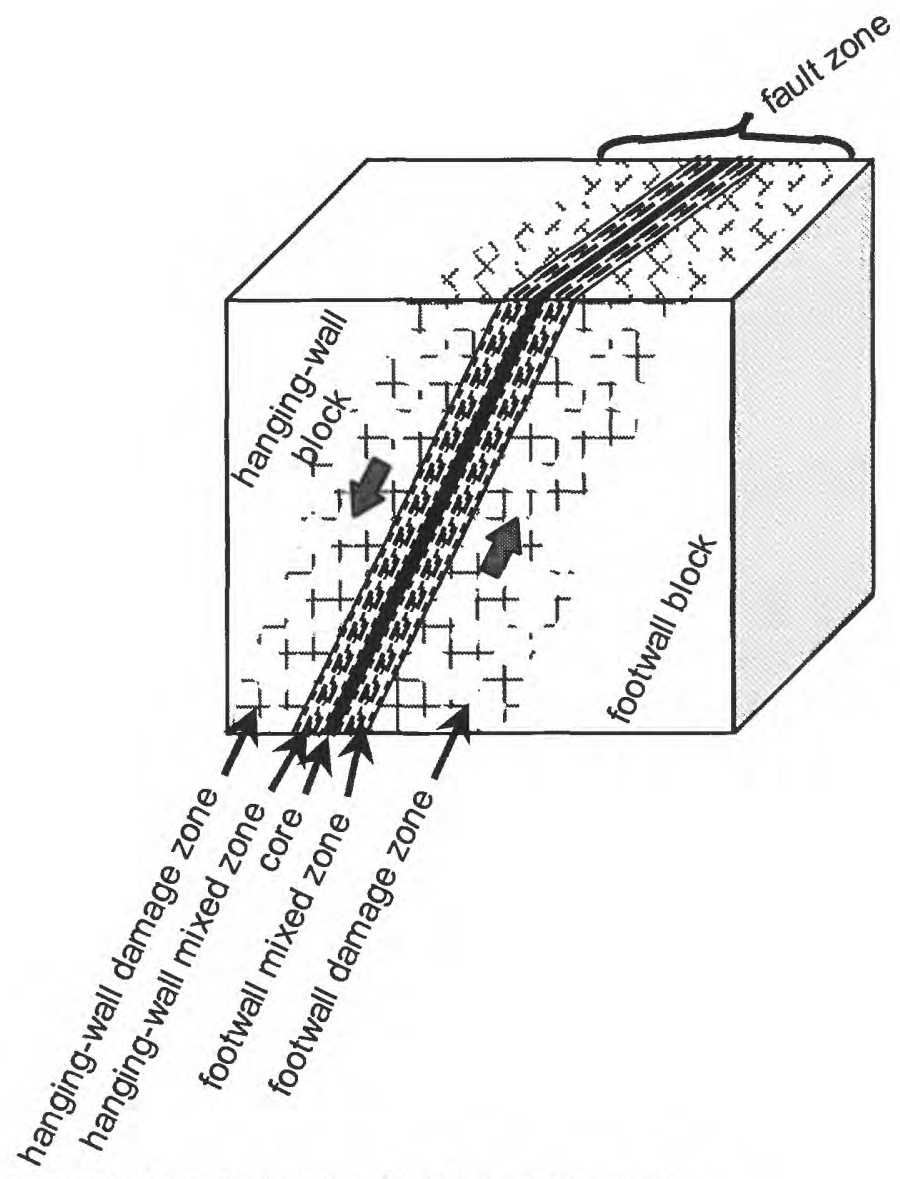

The distribution of fault-zone cement varies both in space and mineralogy. Where present, cement mostly occurs as intergranular and fracture-filling silica(?) or carbonate within sheared mixed-zone lenses of gravel and sand. Prominent, laterally continuous zones of pervasive, sparry carbonate as reported along faults elsewhere in the MRGB (e.g., Mozley and Goodwin, 1995) have only been observed intermittently along the La Bajada fault zone where it juxtaposes gravel of the Santa Fe Group. In the central and western parts of the study area, however, impressive wide (as much as $100 \mathrm{~m}$ ) zones of resistant, strata-bound silica(?) or carbonate cement flank one or both sides of several large faults, including the southernmost Pajarito fault. These strongly cemented zones may currently act as groundwater flow barriers. Some of the mixed zones adjacent to these peripheral cemented zones have contrasting cement mineralogy, indicating that some faults in the study area have accommodated episodic, channelized aqueous fluid-flow and concomitant cementation.

Figure 3. Sketch showing fault zone components.

\section{REFERENCES}

Caine, J.S., Evans, J.P., and Forster, C.B., 1996, Fault zone architecture and permeability structure: Geology, v. 24, p. 1025-1028.

Hickman, S.H., Barton, C.A., Zoback, M.D., Morin, R., Sass, J., and Benoit, R., 1997, In-situ stress and fracture permeability along the Stillwater fault zone, Dixie Valley, Nevada: International Journal of Rock Mechanics and Mining Science, v. 34, no. 3-4, p. 1-10.

Kernodle, J.M., McAda, D.P., and Thorn, C.R., 1995, Simulation of ground-water flow in the Albuquerque Basin, central New Mexico, 1901-1994, with projections to 2020: U.S. Geological Survey Water Resources Investigations Report 94-4251, 114 p., 1 pl.

Mozley, P.S., and Goodwin, L.B., 1995, Patterns of cementation along a Cenozoic normal fault: A record of paleoflow orientations: Geology, v. 23, p. 539-542.

Sibson, R.H., 1990, Conditions for fault-valve behavior, in Knipe, R.J., and Rutter, E.H., (eds.), Deformation mechanisms, rheology, and tectonics: Geological Society of America Special Publication 54, p. 15-28.

Smith, G.A., and Kuhle, A.J., 1997, Late Cenozoic tectonic history of the northern Santo Domingo basin (abs.): New Mexico Geology, v. 19, p. 54. 


\title{
EOLIAN ORIGIN OF SANDY MANTLES ON GENTLY-SLOPING BASALTIC LAVA FLOWS IN THE PLIOCENE CERROS DEL RIO VOLCANIC FIELD NEAR SANTA FE, NEW MEXICO-PRELIMINARY FINDINGS
}

\author{
Ralph R. Shroba and Ren A. Thompson \\ U.S. Geological Survey, National Cooperative Geologic Mapping, \\ Box 25046, MS 913, Denver, CO 80225
}

Grain-size estimates and the composition of sandy mantles in the Cerros del Rio volcanic field, New Mexico, indicate that the sand has an eolian origin. The sandy mantles consist of very fine- to mediumgrained, quartz-rich sand containing scattered basaltic pebbles and cobbles. Gently-sloping basaltic lava flows, erupted from numerous local vent complexes, characterize the Pliocene Cerros del Rio volcanic field. These basaltic flows underlie the sandy mantles, and are the probable source of rubble in the sandy mantles. Basaltic clasts are incorporated either by downslope movement from topographic highs or burrowing. The basaltic lava flows commonly weather to boulder- to granule-size material that contains only minor amounts of sand and finer material, none of which is quartz rich. Strong southwesterly winds may have blown the sand from former sparsely-vegetated or activelyaggrading floodplain deposits along the Rio Grande to the Cerros del Rio volcanic field. Some of the siltand clay-size fraction in the sandy mantles may have been derived from more distant sources. Sheet erosion and sheetwash remobilize sand, and are the processes that cause sand deposition in topographic lows in the lava flows. These characteristics are similar to those for eolian mantles on basaltic lava flows in the Cima volcanic field in southern California (Wells and others, 1985; McFadden and others, 1986).

The presence of surface and buried soils formed in the sand mantles indicates episodic deposition fol- lowed by surface stability and soil development. Shallow (2-3 m thick) stream and road cuts usually expose two deposits. The upper deposit is commonly about $1.2 \mathrm{~m}$ thick. The soil formed in the upper deposit has a weak argillic (Bt) horizon, about $20 \mathrm{~cm}$ thick, that overlies an 80-cm-thick, calcic (Bk) horizon. The Bk horizon has stage I carbonate morphology in the upper half and stage I and locally stage II morphology in the lower half. The lower deposit is similar in character to the upper deposit and is greater than $0.8-1.8 \mathrm{~m}$ thick. Slightly weathered sand at a depth greater than one meter is mostly very fine to medium $(0.05-0.5 \mathrm{~mm})$, light brown to pink (7.5YR 6/4 and 7/4), calcareous, has loamy sand, loam, and silt loam(?) textures, and lacks obvious bedding or sedimentary structures. The soil formed in the lower deposit has a calcic (K) horizon about $35 \mathrm{~cm}$ thick that has stage III carbonate morphology, and is locally overlain by an eroded argillic horizon about $10 \mathrm{~cm}$ thick.

The ages of the above deposits can be estimated by comparing the clay and carbonate morphology of the overlying soils with that of soils formed in surficial deposits of known or inferred age in northern and central New Mexico (Wells and others, 1990; Machette and others, 1997). The clay and carbonate morphology of the Cerros del Rio soils suggests that the upper deposit is latest Pleistocene and may be about 10,000-20,000 years old. The lower deposit is probably late Pleistocene and may be about 35,000 75,000 years old.

\section{REFERENCES}

Machette, M.N., Long, Thomas, and Bachman, G.O., 1997, Laboratory data for calcic soils in central New Mexico: background information for mapping Quaternary deposits in the Albuquerque basin: U.S. Geological Survey OpenFile Report 96-722, 60 p.

McFadden, L.D., Wells, S.G., and Dohrenwend, J.C., 1986, Influences of Quaternary climatic changes on processes of soil development on desert loess deposits of the Cima volcanic field, California: Catena, v. 13, p. 361-389.

Wells, S.G., Dohrenwend, J.C., McFadden, L.D., Turrin, B.D., and Mahrer, K.D., 1985, Late Cenozoic landscape evolution on lava flow surfaces of the Cima volcanic field, Mojave Desert, California: Geological Society of America Bulletin, v. 96, p. 1518-1529. 
Wells, S.G., McFadden, L.D., and Schultz, J.D., 1990, Eolian landscape evolution and soil formation in the Chaco dune field, southern Colorado Plateau, New Mexico: Geomorphology, v. 3, p. 517-546.

\title{
LANDSLIDES OF THE LOS ALAMOS 30' X 60' QUADRANGLE, NORTHERN NEW MEXICO
}

\author{
P.E. Carrara \\ U.S. Geological Survey, National Cooperative Geologic Mapping, \\ Box 25046, MS 913, Denver, CO 80225
}

Recent surficial geologic mapping in the Los Alamos $30^{\prime}$ x 60' quadrangle, northern New Mexico, has identified approximately 150 landslides. An area of about $5000 \mathrm{~km}^{2}$, the Los Alamos 30' x 60' quadrangle includes Bandelier National Monument, Los Alamos National Laboratory, portions of Santa Fe National Forest, and all or part of ten Indian Pueblos (Cochiti, Jemez, Pojoaque, San Felipe, San Ildefonso, Santa Ana, Santa Clara, Santo Domingo, Tesuque, and Zia ). As used here, the term landslide includes a wide variety of landforms produced by the slow to rapid downslope transport of surficial materials or bedrock by gravity resulting from various mass movement processes, including falls, flows, slumps, slides, and combinations thereof. Most of these landslides were previously unmapped, and range in size from small rotational slides and earthflows of about $0.10 \mathrm{~km}^{2}$ to large rotational slides and complex landslides (Varnes, 1978) greater than $10 \mathrm{~km}^{2}$. Landslide types recognized in the map area include earthflows, debris flows, rotational and translational slides, and complex landslides (Varnes, 1978). In total, landslides cover about 10 percent of the Los Alamos $30^{\prime}$ x 60' quadrangle.

A variety of methods were used to identify and map landslide deposits including compilation from existing geologic maps, analysis of 1:40,000 black and white aerial photographs, and reconnaissance fieldwork. Low-sun angle in the early morning and late afternoon highlighted the subdued topography of many older landslide deposits and facilitated field identification. Physical characteristics common to landslides that aided in their identification include: (1) headwall scarps; (2) hummocky topography, including closed depressions and ponds on hillsides; (3) bulging landslide toe; (4) deflection of stream channels by landslide toe; (5) vegetation differences between landslide and adjacent stable areas; (6) bedrock blocks with anomalous dips and strikes; and (7) intact masses of material downslope of their sources. Landslide scarp height, morphology, and topographic relief between the head and toe suggest that many of the larger landslide deposits are more than $100 \mathrm{~m}$ thick.

Although landslides occur throughout the Los Alamos $30^{\prime} \times 60^{\prime}$ quadrangle, they are concentrated in the major canyons. These landslides have formed on steep slopes where resistant volcanic rocks cap fine-grained, weakly indurated sedimentary rocks of low shear strength, such as Santa Fe Group sediments. Previous mapping identified extensive landslide deposits along the Rio Grande in White Rock Canyon (Smith and others, 1976; Reneau and others, 1995; Reneau and Dethier, 1996a and 1996b; and Dethier and Reneau, 1996). Equally large, massive landslides also exist, however, along the Jemez River in the Cañon de San Diego, Vallecito Creek, and the Rio Guadalupe and its two major tributaries, the Rio Cebolla and the Rio de las Vacas. In places, landslides form continuous masses for as much as $10 \mathrm{~km}$ along the valley sides.

Landsliding in the map area probably began in the mid-Pleistocene and has continued to the present. Causes of the numerous landslides in the Los Alamos $30^{\prime} \times 60^{\prime}$ quadrangle may include: (1) downcutting of the canyons through the Pleistocene volcanic rocks exposing the underlying weakly indurated, sedimentary rocks of low shear strength (Reneau and Dethier, 1996a); (2) continued downcutting and removal of lateral support during times of high flow, resulting in the maintenance of steep slopes; and (3) saturation of bedrock and surficial deposits, particularly during glacial periods, with resultant increases in pore pressure and mass (Reneau and Dethier, 1996a). Additionally, earthquakes may have triggered many of the landslides because this area is seismically active. 
Recognizing landslides is important because natural and human-induced factors can influence slope stability. The reduction of lateral support, the removal of vegetation, or an increase in pore pressure could result in landslide reactivation. Landslide-induced damming can create a temporary lake that overflows and bursts, flooding downstream areas. Landsliding in White Rock Canyon dammed the Rio Grande at least four times between 12,000 and $18,000{ }^{14} \mathrm{C}$ years ago (Reneau and Dethier, 1996a).

\title{
REFERENCES
}

Dethier, D.P., and Reneau, S.L., 1996, Lacustrine chronology links late Pleistocene climate change and mass movements in northern New Mexico: Geology, v. 24, p. 539-542.

Reneau, S.L., and Dethier, D.P., 1996a, Late Pleistocene landslide-dammed lakes along the Rio Grande, White Rock Canyon, New Mexico: Geological Society of America Bulletin, v. 108, p. 1492-1507.

Reneau, S.L., and Dethier, D.P., 1996b, Pliocene and Quaternary history of the Rio Grande, White Rock Canyon, and vicinity, New Mexico: New Mexico Geological Society Guidebook, 47th Field Conference, p. 317-324.

Reneau, S.L., Dethier, D.P., and Carney, J.S., 1995, Landslides and other mass movements near Technical Area 33, Los Alamos National Laboratory: Los Alamos National Laboratory Report LA-12955-MS, 48 p.

Smith, R.L, Bailey, R.A., and Ross, C.S., 1976, Geologic map of the Jemez Mountains, New Mexico: U.S. Geological Survey Miscellaneous Investigations Series Map I-571, scale 1:125,000.

Varnes, D.J., 1978, Slope movement types and processes, in Schuster, R.L., and Krizek, R.J., (eds.), Landslides; analysis and control: Transportation Research Board Special Report 176, p. 12-33.

\section{STREAMFLOW LOSS AND INFILTRATION ALONG THE SANTA FE RIVER NEAR LA BAJADA, NEW MEXICO, JUNE 26-27, 1997}

\author{
Carole L. Thomas ${ }^{1}$ and Jim Constantz ${ }^{2}$ \\ U.S. Geological Survey, Water Resources Division, \\ '4501 Indian School Road, N.E., Suite 200, Albuquerque, NM 87110 \\ ${ }^{2} 345$ Middlefield Road, MS 496, Menlo Park, CA 94025
}

Hydrologists have recognized the importance of channel losses in streams of the Rio Grande Basin since the early 1900's. In the Rio Grande Basin, where precipitation is small and water demand is large due to population growth, channel losses due to infiltration along stream channels are particularly important because of their potential to recharge the ground-water system.

A study to: (1) determine streamflow loss patterns and estimates of infiltration rates; and (2) apply the streambed-temperature-profile (stp) method to directly measure infiltration through stream channels in the Middle Rio Grande Basin, New Mexico, began in October 1995. The field sites instrumented and studied within the Middle Rio Grande Basin were the Santa Fe River near La Bajada; Bear Canyon Arroyo in Albuquerque; and Abo Arroyo in the southern Middle Rio Grande Basin. The purpose of this paper is to discuss streamflow-loss patterns and estimated infiltration rates during June 26-27 along a reach of the Santa Fe River near La Bajada (Fig. 4).

The Santa Fe River has certain characteristics that make it a desirable study site. Effluent from the Santa Fe Wastewater Treatment Plant causes this naturally ephemeral stream to flow perennially downstream from the treatment plant, us increasing the opportunity to collect data. The Santa Fe River channel downstream from the treatment plant passes through a deep canyon and onto a gently sloping alluvial valley before intersecting the Rio Grande. This alluvial valley in the La Bajada area is of interest as an area of potential recharge to the ground-water system.

Streamflow measurements are available for the Santa Fe River from March 1970 to the present at a site $(08317200$, TCN1) upstream from La Bajada, New Mexico (Fig. 4). The daily mean flow averaged 


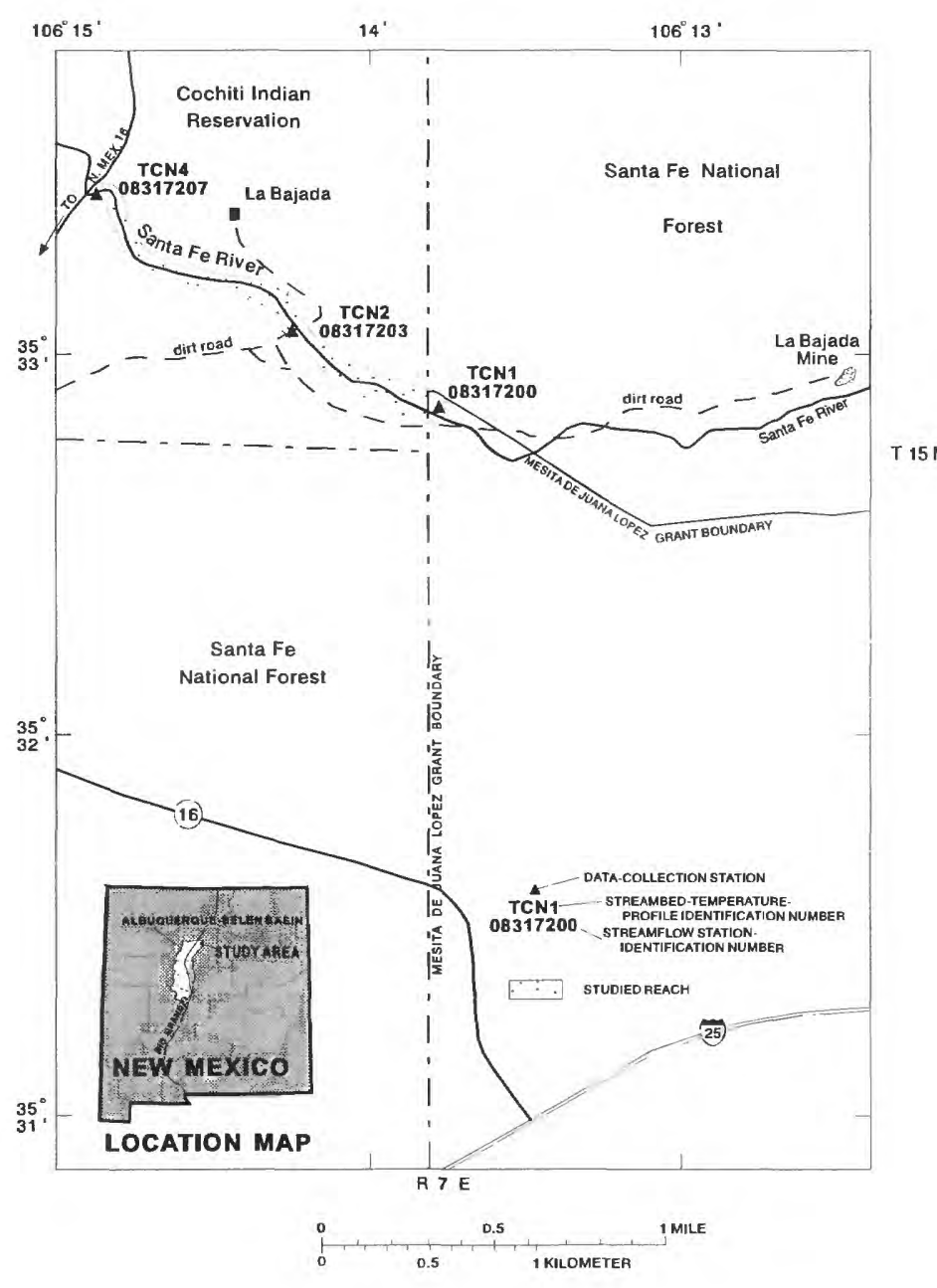

Figure 4. Santa Fe River study area data-collection sites near La Bajada, New Mexico.

for water years 1970-96 is 0.33 cubic meters per second $\left(\mathrm{m}^{3} / \mathrm{s}\right)$ or 11.6 cubic feet per second $\left(\mathrm{ft}^{3} / \mathrm{s}\right)$. The daily mean flow for water year 1996 ranged from 0.08 to $13.7 \mathrm{~m}^{3} / \mathrm{s}$ ( 2.9 to $483 \mathrm{ft}^{3} / \mathrm{s}$ ); 96.4 percent of the daily mean flow values were less than or equal to $0.54 \mathrm{~m}^{3} / \mathrm{s}\left(19 \mathrm{ft}^{3} / \mathrm{s}\right)$. Flows greater than $0.54 \mathrm{~m}^{3} / \mathrm{s}$ $\left(19 \mathrm{ft}^{3} / \mathrm{s}\right)$ generally are a response to storm events or May-June releases from an upstream reservoir. Flow at this station is generally unsteady, with a pattern of a daily minimum in the late afternoon and a daily maximum during the night to early morning hours of a 24-hour cycle.

Two streamflow gages (08317203 and 08317207$)$ installed downstream from the 08317200 site in 1996 allowed collection of streamflow data over two contiguous channel reaches (Fig. 4). The three gages, from upstream to downstream, are also identified as TCN1, TCN2, and TCN4 (Fig. 4). The distance between TCN1 and TCN2 is approximately $800 \mathrm{~m}$, and the distance between TCN2 and TCN4 is approximately $1,700 \mathrm{~m}$. The three streamflow gages were operated from October 1996 through November 1997 for determination of streamflow loss between the gages. Data collection at TCN2 and TCN4 was discontinued on December 4, 1997.

On June 26, 1997, three stream gagers each made seven to eight current-meter, streamflow measurements at TCN1, TCN2, and TCN4 between 0900 and 1600 . Investigators measured the wetted-channel area of the channel reach between TCN1 and TCN4 about every 2 hours during daylight hours from 0900 June 26 to 0900 June 27 . The current-meter, streamfiow measurements were used to develop stage-discharge rating curves for each of the three gaging stations for the June 26-27 period, and they also provided a method for direct calculation of streamflow losses between gaging stations. Irrigationreturn flow of less than $0.007 \mathrm{~m}^{3} / \mathrm{s}(0.25$ $\mathrm{ft}^{3} / \mathrm{s}$ ) was estimated to return to the Santa Fe River between TCN2 and TCN4 from adjacent irrigated fields to the north during the afternoon of June 26. Seepage from beneath the root zone of the irrigated fields also may enter the stream. Therefore, only the channel reach between TCN1 and TCN2 was free of ungaged irrigation-water exchanges, and only discharge calculated from stage data for this reach are reported here (Fig. 5). Data for 1600 to 1830 on June 26 and 0400 to 0900 on June 27 are missing because the stage recorded during these times was outside the limits of the stage-discharge rating curve. Preliminary estimates of streamflow loss between TCN1 and TCN2 ranged from about 0.006 to $0.054 \mathrm{~m}^{3} / \mathrm{s}\left(0.2\right.$ to $\left.1.9 \mathrm{ft}^{3} / \mathrm{s}\right)$ after adjustment for time of travel. The average time of travel was estimated to be about 15 minutes based on velocity measurements at $\mathrm{TCN} 1$ and $\mathrm{TCN} 2$.

Errors are introduced into the calculation of streamflow losses from several sources and affect the observed range of streamflow losses cited above. Current-meter measurements varied due to the difficulty in reading the depth of water on the rod in the moving current. The unsteady flow condition necessitates a time-of-travel adjustment that is dependent on water velocity, and water velocity changes with location of measurement in the cross 


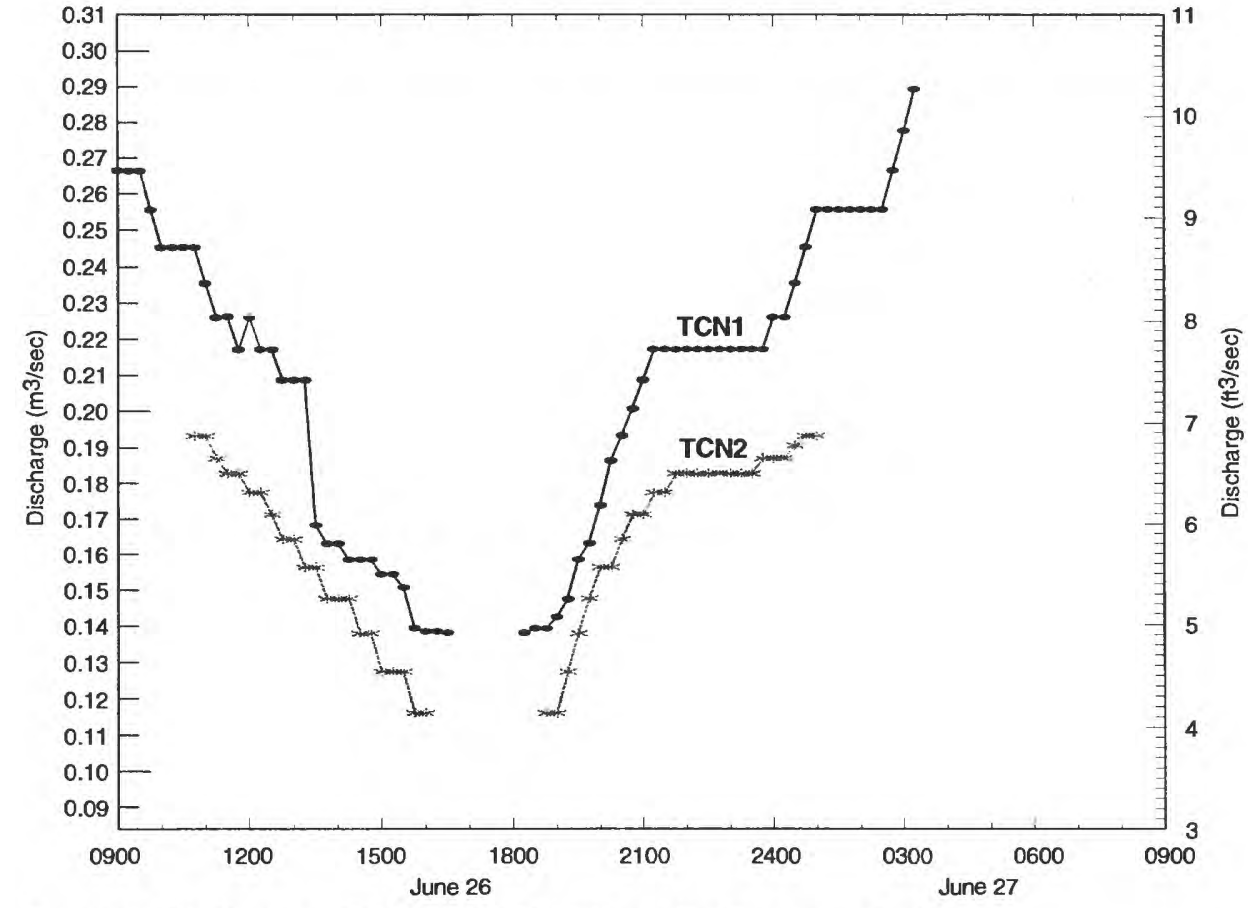

Figure 5. Discharge at TCN1 and TCN2, Santa Fe River near La Bajada. ranged from 4,693 to 6,113 square meters during this time. Based on streamflow-loss and stream-surface-area estimates, the streambed infiltration rates varied from approximately $1 \times 10^{-6}$ to $7 \times 10^{-6}$ $(\mathrm{m} / \mathrm{s})$ during this time. No adjustment for evaporative loss from the stream surface was used in the infiltrationrate calculation because the magnitude of the evaporation rate was small compared to the infiltration rate, and the uncertainty in the number of significant figures for the infiltration rate would have made an adjustment unreasonable. These data suggest that 1 to 6 percent of the measured streamflow loss was due to direct evaporation from the stream surface.

Other teams of investigators are conducting related studies regarding infiltration and potential recharge in the streambed and upland areas adjacent to the Santa Fe River near La Bajada. A.E. Stewart, A. Ronan, and J. Constantz report on streambed infiltration calculated using the stp method in these proceedings. D.A. Stonestrom and K. Akstin report results using environmental-tracer methods of investigation in these proceedings. Results not yet published by J. Nimmo and A. Lewis use a steadystate centrifuge method to determine infiltration and potential recharge.

\section{REFERENCES}

Constantz, J., Thomas, C.L., and Zellweger, G., 1994, Influence of diurnal variations in stream temperatures on streamflow loss and groundwater recharge: Water Resources Research, v. 30, p. 3253-3264.

Thomas, C.L., 1995, Infiltration and quality of water for two arroyo channels, Albuquerque, New Mexico, 1988-92:

U.S. Geological Survey Water-Resources Investigations Report 95-4070, 63 p. 


\title{
ALBUQUERQUE - A HISTORICAL PERSPECTIVE
}

\author{
Michael P. Stier \\ U.S. Geological Survey, National Mapping Division, \\ Box 25046, MS 516, Denver, CO 80225
}

The current character of the City of Albuquerque, New Mexico, is a result of the unique physical geography of the Middle Rio Grande Basin and a dynamic cultural past. From long before Albuquerque's official creation in 1706 to the present time, many events have influenced its existence, sustainability, and growth.

Native Americans settled in the Albuquerque area about 9,500 years ago as evidenced by artifacts found in the area, such as the Clovis point (Simmons, 1982). During this time period, the area had glacial lakes, which were a vital part of the Imperial mammoth's habitat. The Native Americans were primarily attracted to the area to hunt these large mammals using Clovis-pointed spears. With food sources and water nearby, the Native American population flourished in the region for many years.

In the years that followed, from 5,000 to 1,300 years ago, various Native American cultures, such as the Desert and Basket Maker Cultures, occupied the region. About 1,200 years ago, the Basket Makers abandoned their pit-houses and occupied aboveground buildings made of puddled adobe or stone (Simmons, 1982). The Basket Makers eventually became the Pueblos. The name "Pueblo" is derived from the Spanish word meaning "town." Essentially, the entire population of a village lived in one multistoried apartment building.

Spanish explorers came to New Mexico in the sixteenth century in search of "gold, God, and glory." Large numbers of Spanish colonists soon followed the explorers and settled throughout the territory. Numerous conflicts arose between the Pueblo, Comanche, and Navajo Native Americans, who had settled in the area, and the Spaniards. Most of the conflicts were driven by the Native Americans' refusal to give up their native religion in favor of the Spaniards' Christian faith. One such conflict was the Pueblo Revolt of 1680 (Simmons, 1982). The Pueblos fought the Spanish to preserve their social and political structure, sense of world order, and cultural identity.

As more colonists came to the area, the desire to establish Spanish legal settlements increased. Spaniards wanted to establish these settlements, or "villas," in the Middle Rio Grande Valley so that the settlers would have access to churches, public markets, and social activities. In response to the demand for legal settlements, the provisional governor of the territory, Don Francisco y Valdez, petitioned the Spanish government in 1706 to establish the Bosque Grande as a formal villa (Simmons, 1982). This "bosque," which the Spanish called a forest on the banks of a river, had less than the 30 families required to charter a villa under Spanish law. Valdez, however, came up with a plan he felt would increase his chances of getting the villa accepted by the Spanish government. The man who was to approve Valdez's application was Viceroy Francisco Fernandez de la Cueva, the Duke of Alburquerque (a town in western Spain). In his application, Valdez mentioned that he wanted to establish the villa in the name of the Duke, and call it "Alburquerque" (Simmons, 1982). The petition was accepted, and thus was born the City of Alburquerque. The extra " $r$ " was dropped from Alburquerque's spelling in the 1800 's.

Before the actual settlement of Albuquerque, the Spaniards evaluated the bosque to determine the most suitable site for the villa. The location selected had the necessary tillable land, pasture, firewood, and water that the Spanish law required. The elevation of the site was also high enough in relation to surrounding land to avoid periodic flooding by the Rio Grande River. The villa's location also benefited by its proximity to natural avenues of travel, such as the Rio Grande River Valley and Tijeras Canyon. The Rio Grande River Valley offered the most efficient north-south travel, and Tijeras Canyon formed a route through the Sandia and Manzano Moun- 
tains to the eastern plains (Fitzpatrick and Caplin, 1976).

Shortly after Albuquerque's location had been selected and plotted, many buildings were erected. The San Felipe de Neri Church was built first, followed by a house for the priest and government buildings for local officials (Chilton and others, 1984). Colonists settled close to the new villa, built their houses, and opened irrigation ditches to newly planted crops. Since its creation in 1706 to the present, the population of Albuquerque has grown from 252 to 420,000 people (Fitzpatrick and Caplin, 1976).

One of the most significant events in Albuquerque's history was the arrival of the railroad in 1880 . The railroad was the catalyst that ultimately caused Albuquerque to become the major metropolitan area that it is today. With this improved transportation, many of the natural resources Albuquerque possessed could be sold to distant markets within the United States. Industries like agriculture, cattle raising, wool, mining, and textiles prospered with the arrival of the Atchison, Topeka, and Santa Fe Railway (Harber, 1989). The railroad brought people from the eastern United States, who found jobs and settled in the Albuquerque area. In 1909, tuberculosis sufferers came in large numbers seeking the relief offered by the thin atmosphere and dry climate (Fitzpatrick and Caplin, 1976). As more health seekers arrived in Albuquerque, the health-care in- dustry became increasingly important. Sanatoriums were built that specialized in the treatment of lung ailments. Albuquerque's high concentration of patients and sanatoriums eventually attracted pulmonary specialists from around the country, enhancing the city's reputation as a progressive center of medicine (Fitzpatrick and Caplin, 1976).

Through the years, new industries contributed significantly to Albuquerque's growth. During World War II, for example, the population increased substantially with the addition of military establishments such as Kirtland Air Force Base and Sandia National Laboratories (Harber, 1989). In the 1960's and 1970's, electronics and clothing manufacturing contributed to the growth of the city. Since the 1960 's, Albuquerque's downtown has been revitalized, with the Sunport becoming an international airport serving 19,000 passengers each day (Fitzpatrick and Caplin, 1976). Highways like Interstates 40 and 25 have accommodated more efficient auto travel along east-west and north-south corridors. Industrial growth in health care, computer companies, and telecommunications services has created a consistently strong influx of people seeking jobs.

Today, the results of these historical events are apparent. The City of Albuquerque has dramatically increased in population, and the urban area has grown to 120 square miles $\left(310 \mathrm{~km}^{2}\right)$ of land.

\section{REFERENCES}

Chilton, Lance, Chilton, Katherine, Arango, E. Polly, Dudly, Jan, Neary, Nancy, and Stlezner, Patricia, 1984, New Mexico - A New Guide to the Colorful State: University of New Mexico Press, Albuquerque, New Mexico, p. 235262.

Fitzpatrick, George and Caplin, Harvey, 1976, Albuquerque-100 Years in Pictures: Modern Press, Albuquerque, New Mexico, p. 1-163.

Harber, Nancy, 1989, Albuquerque: Modern Press, Albuquerque, New Mexico, p. 34-57.

Simmons, Marc, 1982, New Mexico: University of New Mexico Press, Albuquerque, New Mexico, p. $12-117$. 


\title{
Surficial \& Subsurface Geology
}

\section{PRELIMINARY GEOLOGIC MAPPING IN PARTS OF THE SANTA ANA PUEBLO AND BERNALILLO NW QUADRANGLES, NORTHERN ALBUQUERQUE BASIN}

\author{
Stephen F. Personius \\ U.S. Geological Survey, Geologic Hazards Team, \\ Box 25046, MS 966, Denver, CO 80225
}

Mapping of surficial and bedrock deposits is underway in the Santa Ana Pueblo and Bernalillo NW 7.5' quadrangles north of the Jemez River. Bedrock in these quadrangles consists of Tertiary Santa Fe Group sedimentary rocks and basalts of Santa Ana Mesa. Younger surficial deposits include alluvial fan and colluvial deposits shed off Santa Ana Mesa, fluvial deposits associated with the Jemez River, and eolian sands derived from bedrock and surficial deposits.

The oldest rocks exposed in the map area are mixed eolian and fluvial facies sandstone that appear to correlate with the upper part of the lower Santa $\mathrm{Fe}$ Group, Zia Sand Formation of Manley (1978) and Tedford (1982). In the lower part of the section, these rocks primarily consist of massively crossbedded to parallel bedded, light gray to very pale brown, poorly consolidated fine- to coarse-grained sandstone. Several meter-thick outcrops of weathered volcanic ash in this section in the northeastern part of the Bernalillo NW quadrangle are similar in appearance to tephra exposures along U.S. Highway 44 northwest of Loma Barbon and in the northern part of the Loma Machete 7.5' quadrangle to the south. Higher in the section, these deposits become more fluvial, and consist of parallel-bedded pink siltstone and sandstone, interbedded with eolian crossbedded sandstone.

The Zia Sand Formation is primarily in fault contact with overlying middle Santa Fe Group sedimentary rocks. One possible exposure of a depositional contact between these units is located about $2 \mathrm{~km}$ southeast of Santa Ana (Old Tamaya) Pueblo in the Santa Ana Pueblo quadrangle. Here light reddish brown and tan fine-grained sandstone and minor red mudstone (middle Santa Fe Group) appear to conformably overlie massively crossbedded sandstone interbedded with pink siltstone (upper Zia Sand Formation). Elsewhere, middle Santa $\mathrm{Fe}$
Group rocks consist of similar light reddish brown and tan fine-grained sandstone, red mudstone, and minor thin pebbly conglomerate. Poorly preserved pumice beds may aid in regional correlation of these rocks.

Middle Santa Fe Group rocks are conformably(?) overlain by a thick sequence of red to tan sandstone and conglomerate that underlies the basalts of Santa Ana Mesa; these coarser grained rocks presumably are correlative with the upper Santa Fe Group. They consist of well bedded, poorly indurated sandstone and pebble to minor cobble conglomerate, interbedded with several well developed paleosols that mark hiatuses in deposition. One prominent pumice bed present near the base of these rocks may provide chronological control to supplement the late Pliocene age of the Santa Ana Mesa basalts that cap the stratigraphic section in this area. A few clast-orientation measurements from upper Santa Fe conglomerates indicate easterly and southeasterly transport directions. Western and northwestern sources are consistent with clast compositions dominated by Sierra Nacimiento/western Jemez Mountains rocks (pink granite, Mesozoic and Paleozoic sedimentary rocks, Pedernal Chert, petrified wood, intermediate volcanic rocks). Previous authors (Smith and others, 1970; Manley, 1978) mapped the middle and upper Santa Fe Group rocks in the area as Cochiti Formation, but the transport directions and clast compositions listed above are inconsistent with the volcaniclastic nature of the Cochiti Formation as originally described in the Santo Domingo basin to the northeast (Smith and Lavine, 1996).

Surficial deposits flanking Santa Ana Mesa are dominated by thin deposits of bouldery colluvium that mantle slopes below the mesa-capping basalts. Well-developed (stage III and IV) calcic soils strongly cement these unsorted colluvial mixtures 
of reworked upper Santa Fe Group sand and gravel and bouldery basaltic debris. In numerous locations, colluvial mantles and underlying bedrock deposits have slumped and been remobilized as debris flows. The underlying Santa Fe Group rocks are well exposed in the resulting headscarps.

An extensive sequence of moderate to poorly sorted alluvium forms strath and fill terraces and fans along intermittent stream channels that drain Santa Ana Mesa. Alluvial deposits generally become finer grained and less basaltic downstream; clast rock types are dominated by reworked Santa Fe Group sand and gravel and less abundant basaltic cobbles and boulders. These local alluvial deposits underlie strath and fill terraces that are $2-20 \mathrm{~m}$ above modern drainage channels, and interfinger with and/or overlie fluvial sediments deposited by the Jemez River. Thin sheets and small dune fields of eolian sand of various ages locally cover most alluvial deposits. Eolian deposits are especially common downwind of large arroyos and in areas underlain by poorly consolidated deposits of Zia Sand Formation.

Jemez River terraces mostly consist of thin $(<5-\mathrm{m}$ thick) deposits of well rounded cobbly alluvium on straths cut into the underlying bedrock. Several well-preserved strath terrace remnants are between 5 and $25 \mathrm{~m}$ above the modern river channel, but isolated outcrops of Jemez River alluvium are as high as $60 \mathrm{~m}$ above the Jemez River in scattered lo- cations. Fill terraces are restricted to $\leq 5-\mathrm{m}$-high Holocene terraces, and remnants of an unusual 18to 20-m-thick fill terrace exposed in bluffs along the north side of the river. The high fill terrace is underlain by sand and gravel lenses and a thick sequence of mottled silty clay that locally contains fist-sized crystals of authigenic gypsum. At sites southeast and northwest of Santa Ana Pueblo, the sand and gravel lenses in the fill sequence contain an as yet unidentified reworked pumice deposit that may help in determining the age of this fill sequence.

Structures in bedrock consist of both east- and westdipping, generally north-trending normal faults associated with the Rio Grande rift. Lack of distinctive marker beds precludes precise measurement of offsets, but most of these structures probably have displacements of less than a few hundred meters. Faults that offset the basalts of Santa Ana Mesa are easily mapped on air photos, but most faults in Santa Fe Group rocks are inconspicuous at best. One exception is the Santa Ana fault, an eastdipping fault whose prominent surface expression is enhanced by extensive silica cementation in the footwall. In places, this cemented zone is as much as $100 \mathrm{~m}$ wide, but the degree of cementation varies considerably along strike. Most bedrock units tilt eastward, with dips of $8-15^{\circ}$ common in Santa Fe Group rocks.

\section{REFERENCES}

Manley, K., 1978, Geologic map of the Bernalillo NW quadrangle, Sandoval County, New Mexico: U.S. Geological Survey Geologic Quadrangle Map GQ-1446, scale 1:24,000.

Smith, G.A., and Lavine, A., 1996, What is the Cochiti Formation?, in Goff, F., Kues, B.S., Rogers, M.A., McFadden, L.D., and Gardner, J.N., (eds.), The Jemez Mountains Region: New Mexico Geological Society $47^{\text {th }}$ Field Conference Guidebook, p. 219-224.

Smith, R.L., Bailey, R.A., and Ross, C.S., 1970, Geologic map of the Jemez Mountains, New Mexico: U.S. Geological Survey Miscellaneous Investigations Map I-571, scale 1:125,000.

Tedford, R.H., 1982, Neogene stratigraphy of the northwestern Albuquerque basin, in Grambling, J.A., and Wells, S.G., (eds.), Albuquerque Country II: New Mexico Geological Society $33^{\text {rd }}$ Field Conference Guidebook, p. 273-278. 


\title{
SUBSURFACE STRATIGRAPHY, STRUCTURE, AND HYDROGEOLOGIC FRAMEWORK OF THE SANTA FE GROUP FROM BOREHOLE GEOPHYSICAL LOGS, NORTHERN ALBUQUERQUE BASIN, NEW MEXICO
}

\author{
Sean D. Connell, Bruce D. Allen, and John W. Hawley \\ New Mexico Bureau of Mines and Mineral Resources \\ 2808 Central Ave., S.E., Albuquerque, NM 87106
}

Interpretation of borehole geophysical logs measured for water-supply wells in the Albuquerque metropolitan area of central New Mexico reveal laterally consistent stratigraphic patterns. Such patterns provide a basis for local differentiation of the Neogene Santa Fe Group, the principal aquifer for communities along the Rio Grande Valley. Surface geologic mapping yields important clues to the distribution of faults and alluvial aquifer units in the region, but Quaternary alluvium obscures numerous geologic structures. Subsurface data in the Albuquerque metropolitan area, however, are plentiful; municipal water-supply and groundwatermonitoring wells are closely spaced $(<3 \mathrm{~km})$ and drilled to depths of up to $1000 \mathrm{~m}$. Integration of geologic mapping with borehole geophysical logs, well-completion reports, and driller's logs, as well as examination of cuttings from selected wells delineate faults and hydrostratigraphically significant facies.

Seven hydrostratigraphic units and twelve lithofacies are classified in the subsurface by stratigraphic position, lithologic character (primarily texture, provenance and cementation), age, and environment of deposition. Lithofacies (I-X) are differentiated using driller's logs, cuttings, and geophysical logs (Hawley, 1996; Hawley and Haase, 1992), and are mappable among neighboring wells. Santa Fe Group Lithofacies are grouped into areally extensive upper (USF), middle (MSF), and lower (LSF) hydrostratigraphic units that are broadly equivalent to the informally defined upper buff, middle red, and lower gray formations of Byran and McCann (1937). Lucas and others (1993) recently applied the term Sierra Ladrones Formation to upper buff strata in the Albuquerque area. These hydrostratigraphic units contain coarse-grained fluvial (I, III), fluvialeolian sand (II), basin-floor (alluvial-flat) silt, clay with minor sand (IX, X), and piedmont lithofacies $(\mathrm{V}, \mathrm{VI})$; facies IV, VII and VIII are partly indurated equivalents of II, V and VIII, respectively. Piedmont deposits derived from basement-cored, footwall uplifts along the eastern margin (Sandia and Manzano Mountains) comprise units USF-1 and MSF-1. Fluvial deposits associated with the ancestral Rio Grande (having a north-northeastern provenance) and Rio Puerco (having a north-northwestern provenance) comprise units USF-2/MSF-2 and USF3/MSF-3, respectively. Units USF-4 and MSF-4 have a western basin-margin provenance. LSF is predominantly eolianite (IV) of the Zia Formation and occurs below the range of most Albuquerque wells; however, this unit locally provides potable water in Rio Rancho.

Subsurface correlation of laterally extensive strata provides a basis for local differentiation of the Santa Fe Group. In particular, two sequences of finegrained silty sand and clay (IX and III), first characterized in detail in a corehole drilled near the intersection of $98^{\text {th }}$ Street and Interstate 40 on the West Mesa, are traceable in the subsurface (Allen and others, 1998). These units, provisionally named the upper and lower Atrisco members of the middle red formation, can be traced for several kilometers (Connell and others, 1998). The top of the upper Atrisco member separates coarse-grained sand and gravel of the Sierra Ladrones Formation from underlying fine- to medium-grained silty sand and clay of the middle red formation. This contact also marks an important hydrogeologic boundary between highly productive strata of the USF (I-III) and less-productive aquifers of the MSF (II, III, IX) hydrostratigraphic units. Wells that produce potable water from the USF have specific capacity (SC) values of 66 to $75 \mathrm{gpm} / \mathrm{ft}$ and saturated hydraulic conductivity (k) values of 40 to $71 \mathrm{ft} /$ day $\left(\sim 10^{-4} \mathrm{~m} / \mathrm{s}\right)$. In contrast, wells completed in the MSF aquifer system yield SC values of 6 to $39 \mathrm{gpm} / \mathrm{ft}$ and $\mathrm{k}$ values of about 4 to $12 \mathrm{ft} /$ day $\left(\sim 10^{-5}\right.$ to $\left.10^{-4} \mathrm{~m} / \mathrm{s}\right)$.

Subsurface data also illustrate the influence of buried geologic structures on basin architecture in the 
Albuquerque metropolitan area. A series of northstriking, down-to-the-west normal faults, such as the Sandia fault zone, mark the eastern margin. The East Heights fault zone generally marks the eastern limit of highly transmissive deposits of the Sierra Ladrones Fm. Eastward thickening of Sierra Ladrones strata and divergence of marker beds are local indications of syndepositional faulting. Initial findings also suggest that the top of the Sierra Ladrones Formation (USF) is diachronous and has migrated eastward during the Plio-Pleistocene in re- sponse to tectonic subsidence along the eastern ba$\sin$ margin. Such a response would have caused early Pleistocene deposition of the highly transmissive Sierra Ladrones Formation (USF-2) beneath much of Albuquerque.

Synthesis of surface mapping and subsurface data shows poorly exposed faults that influence the distribution of aquifer units segment the basin. Only through the integration of these data sets can we recognize major structural and stratigraphic trends.

\title{
REFERENCES
}

Allen, B.D., Connell, S.D., and Hawley, J.W., 1998, Core drilling provides information about Santa Fe Group aquifer beneath Albuquerque's West Mesa: New Mexico Geology, v. 20, p. 8-13.

Bryan, K., and McCann, F.T., 1937, The Ceja del Rio Puerco--a border feature of the Basin and Range province in New Mexico, part I, Stratigraphy and structure: Journal of Geology, v. 45, p. 801-828.

Connell, S.D., Allen, B.D., and Hawley, J.W., 1998, Subsurface stratigraphy of the Santa Fe Group from borehole geophysical logs, Albuquerque area, New Mexico: New Mexico Geology, v. 20, p. 2-7.

Hawley, J.W., 1996, Hydrogeologic framework of potential recharge areas in the Albuquerque Basin, central New Mexico, in Hawley, J.W., and Whitworth, T.M., (eds.), Hydrogeology of potential recharge areas and hydrogeochemical modeling of proposed artificial-recharge methods in basin- and valley-fill aquifer systems, Albuquerque Basin, New Mexico: New Mexico Bureau of Mines and Mineral Resources Open-File Report 402-D, Chapter 1.

Hawley, J.W., and Haase, C.S., (compilers), 1992, Hydrogeologic framework of the northern Albuquerque Basin: New Mexico Bureau of Mines and Mineral Resources Open-File Report 387, variously paged.

Lucas, S.G., Williamson, T.E., and Sobus, J., 1993, Plio-Pleistocene stratigraphy, paleoecology, and mammalian biochronology, Tijeras arroyo, Albuquerque area, New Mexico: New Mexico Geology, v. 15, p. 1-8.

\section{EXPRESSION OF FAULTS IN HIGH-RESOLUTION AEROMAGNETIC DATA NEAR ALBUQUERQUE, NEW MEXICO-PRELIMINARY RESULTS}

\author{
V.J.S. Grauch \\ U. S. Geological Survey, Mineral Resources Team, \\ Box 25046, MS 964, Denver, CO 80225 \\ $<$ tien@usgs.gov>
}

High-resolution aeromagnetic surveys were conducted in 1996 and 1997 in the Middle Rio Grande Basin near Albuquerque, New Mexico. Maps from these surveys show expressions of faults, volcanic rocks, and lithologic variations within the sediments of the Santa Fe Group aquifer system. The Tertiary to Quaternary sediments of the aquifer system can be divided into hydrostratigraphic units exhibiting a wide permeability range. Thus, delineation of faults, which may juxtapose different hydrostratigraphic units, and identification of variations in rock types are important for understanding the hydrogeology of the Basin. Moreover, certain fault zones have a unique magnetic signature unrelated to the units they juxtapose. This signature may indicate fracturing or changes in mineralogy at the fault zones that might be hydrogeologically significant. Two faults that are known hydrologic barriers exhibit this signature, which suggests a relation between the magnetic signature and reduced permeability. 
In 1996, aeromagnetic data were acquired along east-west flight lines using two different specifications. The Rio Rancho survey, covering an area north and west of Albuquerque that included Rio Rancho and Sandia Pueblo lands, was flown at 100$\mathrm{m}$ line spacing and at $100 \mathrm{~m}$ height above ground level (AGL). The Albuquerque West survey, covering the West Mesa area to Rio Puerco, was flown using 150-m line spacing and at a height of $150 \mathrm{~m}$ AGL. Exceptions to the specifications for both surveys were over urban areas where heights reached about $300 \mathrm{~m}$ AGL. Tests on the results from these surveys indicated that optimum specifications for resolving features of interest while keeping costs down are 150-m line spacing and 150-m AGL. The equal ratio of line spacing to height above ground gives proper sampling of the magnetic field so that the observed data can be filtered to enhance the desired details. In late 1997, two contiguous surveys were acquired using these optimum specifications: the Kirtland-Sandia survey, covering Kirtland Airforce Base and Sandia National Laboratories; and the Isleta survey, covering Isleta Pueblo lands and the village of Los Lunas, south of Albuquerque. Only preliminary data are currently available from the 1997 surveys.

All the aeromagnetic data show expressions of numerous sinuous, generally north- to northnortheast-striking faults within the basin, as well as expressions of exposed and shallowly buried volcanic rocks, crystalline basement at the shoulders of the Rio Grande Rift, lithologic variations within the Santa Fe Group, and anthropogenic structures. Magnetic expressions due to intra-basinal faults were identified by: (1) semi-linear magnetic expressions that have little relation to topography; (2) association with surface exposures of faults determined from discussions with geologists mapping in the area; and (3) correspondence to general locations of faults determined from drill-hole information. Linear magnetic anomalies that have no relation to topography indicate that the anomalies have a geologic rather than geomorphologic origin. Associations with exposed or inferred faults give the best confidence that the magnetic features are expressions of faults. This confidence allows faults to be delineated by the aeromagnetic data in areas covered by widespread eolian sand. On the other hand, not all mapped faults have magnetic expression.
Faults that offset volcanic rock are displayed as linear breaks in the highly variable magnetic expression of the volcanic rocks. Some of these breaks can be extended as linear anomalies into neighboring sediments. For example, the magnetic expression of basalt related to Albuquerque volcanoes is cut by linear breaks on both sides of the vent area, supporting the idea of a north-striking, basalt-filled graben. The graben faults extend $10-15 \mathrm{~km}$ beyond the area of basalt into alluvial areas, as expressed by linear anomalies. The western fault extends to the north and the eastern one to the south.

Magnetic anomalies associated with intrasedimentary faults are linear with amplitudes ranging from 2 to 10 nanoTesla. Two types of signatures can be recognized: (1) paired highs and lows, and (2) a low flanked by highs on either side. The first signature is most likely caused by significant offsets between different units within the Santa Fe Group. From preliminary models, significant offsets can be on the order of a hundred meters or more. In addition, magnetic material can be juxtaposed against less magnetic material on either the down-thrown or up-thrown side of the fault.

The second type of magnetic signature is produced by lower values of magnetization within a zone encompassing the fault. From preliminary models, the zone is generally about $250-300 \mathrm{~m}$ wide. The lower values could be caused by brecciation, chemical changes due to circulating fluids, a lithologic difference originating from fault-controlled sedimentation, or some combination of these factors. The signature is easiest to recognize from horizontalgradient enhancements of the magnetic data, which indicate that faults with this signature are widespread. Segments of the Hubbell Springs and Cat Mesa faults exhibit this signature in preliminary aeromagnetic data south of Albuquerque. Both faults are considered hydrologic barriers and can be used to bound hydrologic models of the basin on the west (Cat Mesa) and east (Hubbell Springs) sides. The correspondence suggests that the mechanism that reduces magnetization along the fault zone also reduces permeability. Further work is required, however, to understand the mechanism and to establish this relation. 


\title{
PRELIMINARY GEOPHYSICAL RESULTS FROM THE RIO RANCHO AREA, NEW MEXICO
}

\author{
Maria Deszcz-Pan ${ }^{1}$, Brian Rodriguez ${ }^{1}$, V.J.S. Grauch ${ }^{1}$, \\ Byron D. Stone ${ }^{2}$, David A. Sawyer ${ }^{3}$, and Victor Labson ${ }^{1}$ \\ ${ }^{1}$ U.S. Geological Survey, Mineral Resources, MS 964, \\ Box 25046, Denver, CO 80225 \\ ${ }^{2}$ U.S. Geological Survey, National Cooperative Geologic Mapping, \\ 101 Pitkin St., East Hartford, CT 06108 \\ ${ }^{3}$ U.S. Geological Survey, National Cooperative Geologic Mapping, MS 913, \\ Box 25046, Denver, CO 80225 \\ <maryla@usgs.gov>
}

A combined airborne time-domain electromagnetic pulse (TDEM) and magnetic survey was conducted in March 1997 in the Rio Rancho area, New Mexico. The survey area generally coincides with a highresolution magnetic survey conducted in 1996 (see Grauch et al., this volume). In addition to the airborne surveys, ground electrical resistivity (DC) and audiomagnetotelluric (AMT) studies were performed in the summer of 1997 . The primary objective of the geophysical surveys was to delineate geological structures and facies changes within the Santa Fe Group aquifer system that are important to the local and regional hydrogeology. The surveys were based on the assumption that the axial-channel gravel deposits, which are the main aquifers in the Middle Rio Grande Basin, will have a higher electrical resistivity than surrounding finer-grained materials.

Several factors dictated the decision to use the airborne TDEM method for this investigation. First, airborne methods efficiently provide significant amounts of information over a wide area. Second, airborne TDEM can be used to infer the general distribution of the electrical resistivity up to a depth of several hundred meters from the surface-a greater depth penetration than available from other airborne electromagnetic (EM) methods. Even though the method has been used for many years as a geophysical prospecting tool to find massive sulfides, its use in hydrogeological mapping is new. Therefore, interpretative techniques to map the subtle resistivity variations due to facies changes are not yet fully developed.

The GEOTEM TDEM system (operated by Geoterrex) sends and receives EM signals, and the recorded voltages are converted to resistivity. An antenna mounted on the airplane generates a burst of EM signal in the GEOTEM TDEM system. In the receiver, the arriving EM signal is recorded as a voltage at specific times after each pulse (TDEM response). The received signal is affected by many factors, but, ideally, the shape and strength of the signal depends on the resistivity distribution in the subsurface. Therefore, using appropriate algorithms, the measured voltages can be converted to the electrical resistivity distribution with depth. In general, a stronger signal indicates lower resistivity and a weaker signal indicates higher resistivity. Earlier arrival times provide information on the shallower depths, and later arrival times provide information on the deeper depths.

The Rio Rancho survey covered a $25 \mathrm{~km} \times 40 \mathrm{~km}$ area. It was flown using $400-\mathrm{m}$ flight spacing at 120 $m$ above ground level (AGL). Over urban areas, the flight height reached about $250 \mathrm{~m}$ AGL. A data point was recorded every $30 \mathrm{~m}$ along the flight direction.

Cultural features affect the response of the TDEM system. Fences, pipelines, communication lines, railways and other man-made conductors can contaminate the responses. The areas affected by such cultural noise can not be used for interpretation. The majority of cultural anomalies can be easily identified, but sometimes the cultural noise response is very subtle and can be mistaken for the earth response. Cultural noise severely affects the Rio Rancho area, especially in the central and eastern part of the survey.

In order to obtain resistivity information in areas affected by cultural noise and to provide an independent check on the interpretation of TDEM models, we collected ground-based DC and AMT data in the study area. Preliminary resistivity values interpreted at a few points from AMT, DC and TDEM models are in the range of 100 to $5 \mathrm{ohm}-\mathrm{m}$, which is also a resistivity range measured by induction logs in wells scattered over the area. 
Our preliminary results, in the form of maps of voltages recorded at different times, show a good agreement between the TDEM response and other subsurface information. Clear changes in the TDEM response occur at several mapped faults and at faults inferred from the high-resolution magnetic survey. Voltage maps for most times show a similar geographic pattern that can be divided into five areas of distinct voltage responses. On the east, we observe a very low voltage area that can be related to thick axial-gravel deposits of the Ancestral Rio Grande inferred from well logs. The western boundary of this low voltage area is roughly $2 \mathrm{~km}$ east of the inferred western boundary of the thick axial-river deposits. To the northwest, an area of higher voltages coincides with the Zia Horst, in which uplifted silty units of the lowest Santa Fe Group deposits are near the surface. To the south of the Zia Horst, at the center of the map, lower voltages correspond in part to channel-rich middle Santa Fe units. The voltage pattern suggests this unit does not extend as far north as expected. On the other hand, exposed basalt in the southern part of this area, which is prominent on the magnetic map, is not observed on the voltage maps. Either the basalt is too thin to be detected or its electrical properties are similar to the underlying deposits. On the west, the Mesozoic Mancos shale likely causes the highest voltages; the eastern boundary of this area coincides with the Sandhill Fault. Between the highest voltages on the west and the lower voltages in the center of the map is an area of moderate voltages, which is bounded on the east by two faults clearly observed on the magnetic data.

We need to determine the electrical resistivity values that correspond to particular geological units. We had hoped to use the contractor-provided electrical conductivity-depth-thickness (CDT) profiles to identify the zones of different resistivity, but preliminary comparison of the profiles with induction logs was disappointing in the Rio Rancho area (in the Cochiti area, the few logs and AMT models roughly agreed). Another algorithm, developed and owned by BHP geophysical company, provided resistivity sections that closely correlated with well logs and available geological sections. We need to develop an algorithm that will invert the data to reliable resistivity-depth information.

\title{
ELECTROMAGNETIC SURVEYS IN THE RIO GRANDE FLOODPLAIN, MIDDLE RIO GRANDE BASIN, NEW MEXICO_SECOND-YEAR STATUS
}

\author{
Joseph M. Sterling ${ }^{1}$ and James R. Bartolino ${ }^{2}$ \\ 'New Mexico Institute of Mining and Technology, Socorro, NM 87801 \\ ${ }^{2}$ U.S. Geological Survey, Water Resources Division, \\ 4501 Indian School Road, N.E., Suite 200, Albuquerque, NM 87110
}

Quantifying the hydraulic linkage of the Rio Grande to the Santa Fe Group aquifer system is of prime importance in managing the water resources in the Middle Rio Grande Basin. The river and aquifer are linked through the approximately 25-meter (m)thick sequence of inner-valley alluvium underlying the Rio Grande flood plain. These alluvial deposits, which contain sediments ranging from cobbles to clay, are a major factor controlling the volume of water that can move between the Rio Grande and the aquifer system. In the ground-water-flow model of Kernodle and others (1995) vertical hydraulic-conductivity values for the inner-valley alluvium were assumed to range from 12.2 meters per day ( $\mathrm{m} /$ day) for most of the inner-valley alluvium to $0.15 \mathrm{~m} /$ day for an area of silty clay. Silty-clay layers exist within much of the inner-valley alluvium; although many of these layers are discontinuous, they are as thick as 4 to $6 \mathrm{~m}$ locally. Information on the distribution and geometry of siltyclay layers in the inner-valley alluvium is essential for quantifying the amount of water transmitted between the Rio Grande and the Santa Fe Group aquifer system. This article describes the preliminary results of the second phase of a study evaluating the use of electromagnetic surveys to provide this information. Woodward (1997) described results of the first phase. 
The second phase of this study was conducted in the spring and summer of 1997 to determine the distribution and geometry of significant silty-clay layers buried in the inner-valley alluvium. Surveys were conducted using a ground-transient electromagnetic system: the Geonics EM-34 (frequency domain). (The use of firm, trade, and brand names in this report is for identification purposes only and does not constitute endorsement by the U.S. Geological Survey.) During the second phase, 31 EM-34 sections ranging from 80 to $1,600 \mathrm{~m}$ long were located in the Rio Grande floodplain between Alameda and Rio Bravo Boulevards (Fig. 6). Stations were spaced $20 \mathrm{~m}$ apart in each section, and both horizontal- and vertical-dipole measurements were collected at three intercoil separation distances $(5,10$, and $20 \mathrm{~m})$.

For preliminary interpretation, sections with terrain-conductivity values larger than 40 millimhos per meter $(\mathrm{mmhos} / \mathrm{m})$ were assumed to contain detectable amounts of silty clay because of correlation with lithologic logs. In addition, sections that had stations that had widely contrasting terrainconductivity values $(>10 \mathrm{mmhos} / \mathrm{m})$ for different intercoil spacings probably contain detectable amounts of silty clay because of the inhomogeneity of the measurements. By using these criteria, all or parts of 14 of the 31 survey lines are probably underlain by silty-clay layers. Specific conductance of the ground water was assumed to have a uniform effect on terrain-conductivity values; Bexfield and Anderholm (1997) measured specific conductance ranging from 280 to 1,771 microsiemens per centimeter at $25^{\circ}$ Celsius in water from 14 wells in the Rio Grande floodplain in the Middle Rio Grande Basin. Topographic effects were not considered for these preliminary interpretations.

Terrain-conductivity values for two survey lines show differences (Fig. 7); one section represents terrain-conductivity values for alluvium without siltyclay layers, and the second section represents terrain-conductivity values for alluvium with silty-clay layers. The I40S1 survey line was on the east side of the Rio Grande, began approximately $200 \mathrm{~m}$ south
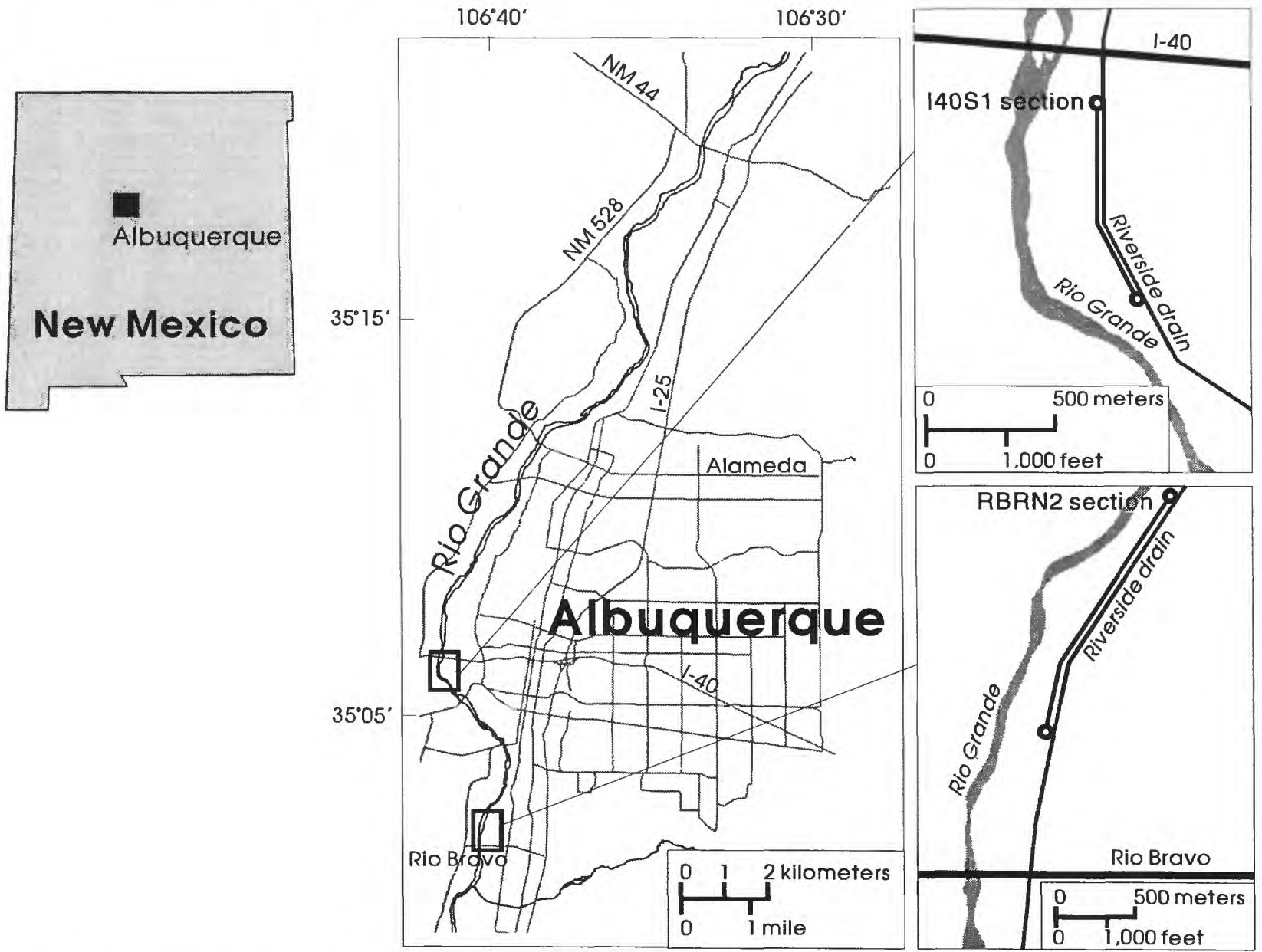

Figure 6. Albuquerque area and detailed maps of the I4OS1 and RBRN2 sections. 

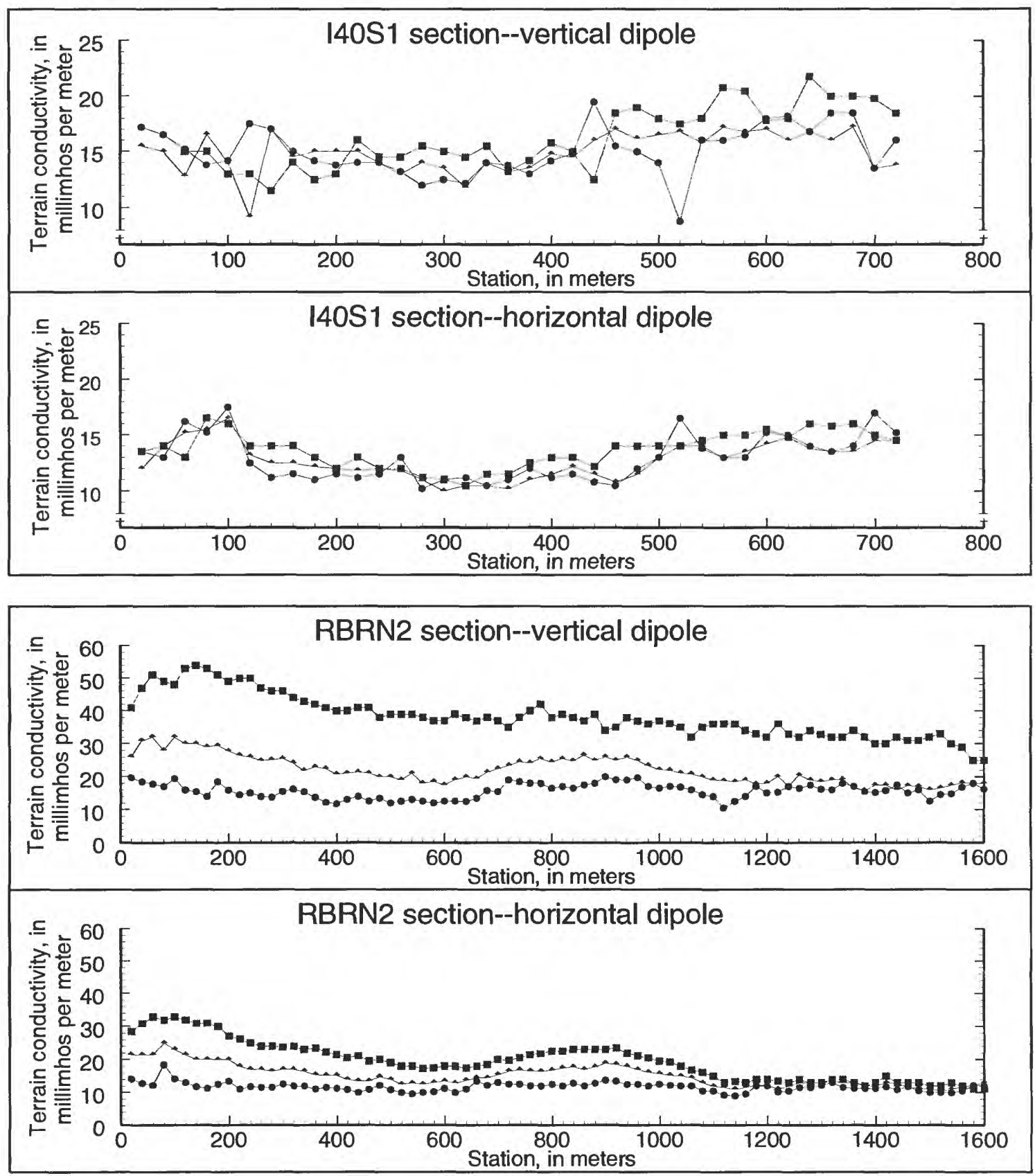

EXPLANATION

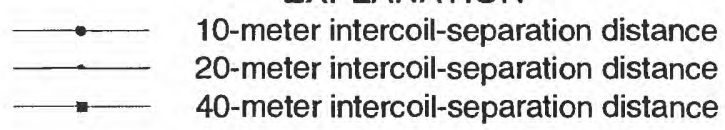

Figure 7. Terrain conductivity along the I4OS1 and RBRN2 sections. Note the similarity of conductivity values in the I40S1 section and the contrasts between conductivity values for different spacings in the RBRN2 section.

of Interstate Highway 40, and was $720 \mathrm{~m}$ long (Fig. 6). The RBRN2 survey line also was on the east side of the river, began approximately $1 \mathrm{~km}$ north of Rio Bravo Boulevard, and was 1,600 m long (Fig. 6).

Table 2 summarizes the range, variability, and interpretation of terrain-conductivity values for the two sections shown in Figure 7. In section I40S1, the low terrain-conductivity values $(<40 \mathrm{mmhos} / \mathrm{m})$ and the small variability of terrain-conductivity values $(<10 \mathrm{mmhos} / \mathrm{m})$ at each station strongly indicate a lack of silty-clay layers in the alluvium throughout this section. In section RBRN2, the high terrain-conductivity values likely indicate silty-clay layers within the alluvium throughout the section; the large variability of terrain-conductivity values at 
Table 2. Summary of range, variability, and interpretation of terrain-conductivity values for sections I40S1 and RBRN2.

\begin{tabular}{|c|c|c|c|c|c|}
\hline \multirow[t]{2}{*}{ Section } & \multirow{2}{*}{$\begin{array}{l}\text { Stations } \\
\text { (m) }\end{array}$} & \multirow{2}{*}{$\begin{array}{l}\text { Range of ter- } \\
\text { rain- } \\
\text { conductivity } \\
\text { values } \\
(\mathrm{mmhos} / \mathrm{m})\end{array}$} & \multicolumn{2}{|c|}{$\begin{array}{c}\text { Variability of terrain } \\
\text { conductivity values at } \\
\text { each station (mmhos } / \mathrm{m} \text { ) }\end{array}$} & \multirow[t]{2}{*}{ Interpretation } \\
\hline & & & $\begin{array}{l}\text { Vertical } \\
\text { dipole }\end{array}$ & $\begin{array}{c}\text { Horizontal } \\
\text { dipole }\end{array}$ & \\
\hline I40S1 & All & $10-29$ & $<10$ & $<4$ & Alluvium without silty-clay layers \\
\hline \multirow[t]{4}{*}{ RBRN2 } & $0-440$ & $10-55$ & $10-40$ & $10-20$ & $\begin{array}{l}\text { Alluvium with strong indication of } \\
\text { silty-clay layers }\end{array}$ \\
\hline & $460-760$ & $10-55$ & $10-40$ & $<10$ & $\begin{array}{l}\text { Alluvium with likely indication of } \\
\text { silty-clay layers }\end{array}$ \\
\hline & $780-940$ & $10-55$ & $10-40$ & $10-20$ & $\begin{array}{l}\text { Alluvium with strong indication of } \\
\text { silty-clay layers }\end{array}$ \\
\hline & $960-1,600$ & $10-55$ & $10-40$ & $<10$ & $\begin{array}{l}\text { Alluvium with likely indication of } \\
\text { silty-clay layers }\end{array}$ \\
\hline
\end{tabular}

stations 0 to $440 \mathrm{~m}$ and 780 to $940 \mathrm{~m}$ strongly indicates silty-clay layers within the alluvium at these stations.

Terrain-conductivity data collected at each station for the three intercoil separation distances at each dipole orientation are currently (1997) being entered into the EMIX 34 Plus computer program (Interpex Limited, 1989) to aid in interpretation. This software allows terrain-conductivity measurements to be interpreted in terms of one-dimensional layered earth models with as many as three plane layers at each station to provide a probable geologic section.
Such interpretations will be checked against lithologic and petrophysical logs from wells and borings made near the sections. Because of substantial variations in terrain conductivity from cultural or other interferences, however, there may be difficulties in interpretation.

This geophysical approach to delineate buried siltyclay layers is anticipated to complement work begun by personnel of the New Mexico Bureau of Mines and Mineral Resources to map the physical stratigraphy of the inner-valley alluvium by interpreting petrophysical and drillers' logs.

\section{REFERENCES}

Bexfield, L.M., and Anderholm, S.K., 1997, Water-quality assessment of the Rio Grande Valley, Colorado, New Mexico, and Texas-Ground-water quality in the Rio Grande flood plain, Cochiti Lake, New Mexico, to El Paso, Texas, 1995: U.S. Geological Survey Water-Resources Investigations Report 96-4249, 93 p.

Interpex Limited, 1989, EMIX 34 Plus software: Golden, Colorado.

Kernodle, J.M., McAda, D.P., and Thorn, C.R., 1995, Simulation of ground-water flow in the Albuquerque Basin, central New Mexico, 1901-1994, with projections to 2020: U.S. Geological Survey Water-Resources Investigations Report 94-4251, 114 p., 1 pl.

Woodward, D.G., 1997, Electromagnetic surveys in the Rio Grande flood plain, Middle Rio Grande Basin, New Mexico, in Bartolino, J.R., (ed.), U.S. Geological Survey Middle Rio Grande Basin Study--Proceedings of the first annual workshop, Denver, Colorado, November 12-14, 1996: U.S. Geological Survey Open-File Report 97-116, p. 30-31. 
$98^{\text {th }}$ Street Core

\title{
THE 98TH STREET CORE: KEY TO ANALYSIS OF SANTA FE GROUP STRATIGRAPHY AND HYDROGEOLOGY IN THE CENTRAL MIDDLE RIO GRANDE BASIN
}

\author{
Byron D. Stone' ${ }^{1}$ and Bruce D. Allen ${ }^{2}$ \\ ${ }^{1}$ U.S. Geological Survey, National Cooperative Geologic Mapping Team, \\ 101 Pitkin St., East Hartford, CT 06108 \\ ${ }^{2}$ New Mexico Bureau of Mines and Mineral Resources, 2808 Central Ave., S.E., Albuquerque, NM 87106
}

Core samples, cuttings, and geophysical logs from the $1560-\mathrm{ft}(475.5-\mathrm{m})$ core hole drilled at $98^{\text {th }}$ Street on the west side of Albuquerque provide key stratigraphic and hydraulic-property information for the upper clastic sediments of the Santa Fe Group. The Santa Fe Group is an important unit because the sediments form the principal aquifer in the region. These core samples $(751.5 \mathrm{ft}, 229 \mathrm{~m})$ are the only undisturbed samples of non-lithified and lithified sediments of the upper part of the Santa Fe Group that have been collected in this area. The samples have allowed us to characterize the lithic and sedimentologic features of this part of the section, and to correlate the geology with geophysical-log characteristics, magnetic susceptibility measurements, hydraulic variables, and trace-element geochemistry. This report chiefly addresses the stratigraphic and lithologic features determined from the $98^{\text {th }}$ Street core hole; Hudson and others (this volume) address paleomagnetic and rock magnetic studies.

The U.S. Geological Survey and the City of Albuquerque cooperatively drilled the core hole and an adjacent water-level monitoring well. The New Mexico Bureau of Mines and Mineral Resources and the New Mexico Office of the State Engineer collaborated in the investigation to improve understanding of aquifer characteristics and controls on ground-water availability and quality.

Three informal lithostratigraphic units summarize the present stratigraphic framework for the $98^{\text {th }}$ Street site (Fig. 8). The top unit, 0-19 ft depth, consists of Quaternary eolian sand and valley-border alluvium. Underlying coarse-grained deposits, 19$97 \mathrm{ft}$ depth, are correlated with the upper unit of the Santa Fe Group (USF, Fig. 8; equivalent to the Ceja Member of the Santa Fe Formation of Kelly, 1977, and correlated with the Sierra Ladrones Formation of Machette, 1978). Gravel-clast composition indi- cates a northwestern source for this unit; basal pebble-cobble gravel disconformably overlies finer grained beds.

The sequence of interbedded sand, silty sand, silty clay, and clay from $97 \mathrm{ft}$ to $1560 \mathrm{ft}$ is correlated tentatively with the middle unit of the Santa Fe Group (equivalent to the upper part of the Middle Red Member of Kelly, 1977). Allen and others (1998) and Connell and others (1998), however, correlate the sandy interval between $97 \mathrm{ft}$ and $441 \mathrm{ft}$ with the lower part of the Sierra Ladrones Formation (included in the upper Santa Fe hydrostratigraphic unit of Hawley and others, 1995). Connell and others (1998) correlate the $441-787 \mathrm{ft}$ interval with the extensive Atrisco Member (informal) of Connell and others (1998). It consists of thin-bedded fine sand, poorly sorted silty sand, and laminated silt, fine sand, and clay. Core samples and geophysical logs demonstrate that this interval is finer-grained than overlying and underlying beds. The interval contains numerous and relatively thick sequences of red (2.5YR 4/6; Munsell, 1975) to reddish brown (2.5-5YR 5/4) clay, and silt in sets of laminated beds commonly $<2 \mathrm{ft}(0.61 \mathrm{~m})$ thick, but as much as 4.45 $\mathrm{ft}(1.36 \mathrm{~m})$ thick. A distinctive olive-colored zone between $709 \mathrm{ft}$ and $756 \mathrm{ft}$ consists of light-olive brown (2.5Y 5/2-4) to dark-grayish brown (2.5Y $4 / 2$ ) silty clay, and silty fine to medium sand.

A series of laterally extensive, fluvial overbank deposits makes up the entire upper part of the middle Santa Fe unit (97-787 ft). Such deposits probably accumulated in shallow abandoned channels or backswamp ponds, the extent of which may have been related to syndepositional faults that controlled the location of the main river channel, tributary channels, and overbank flats (Fig. 9). A playalake origin for these fine-grained beds is inconsistent with the evidence; no evaporite minerals, 


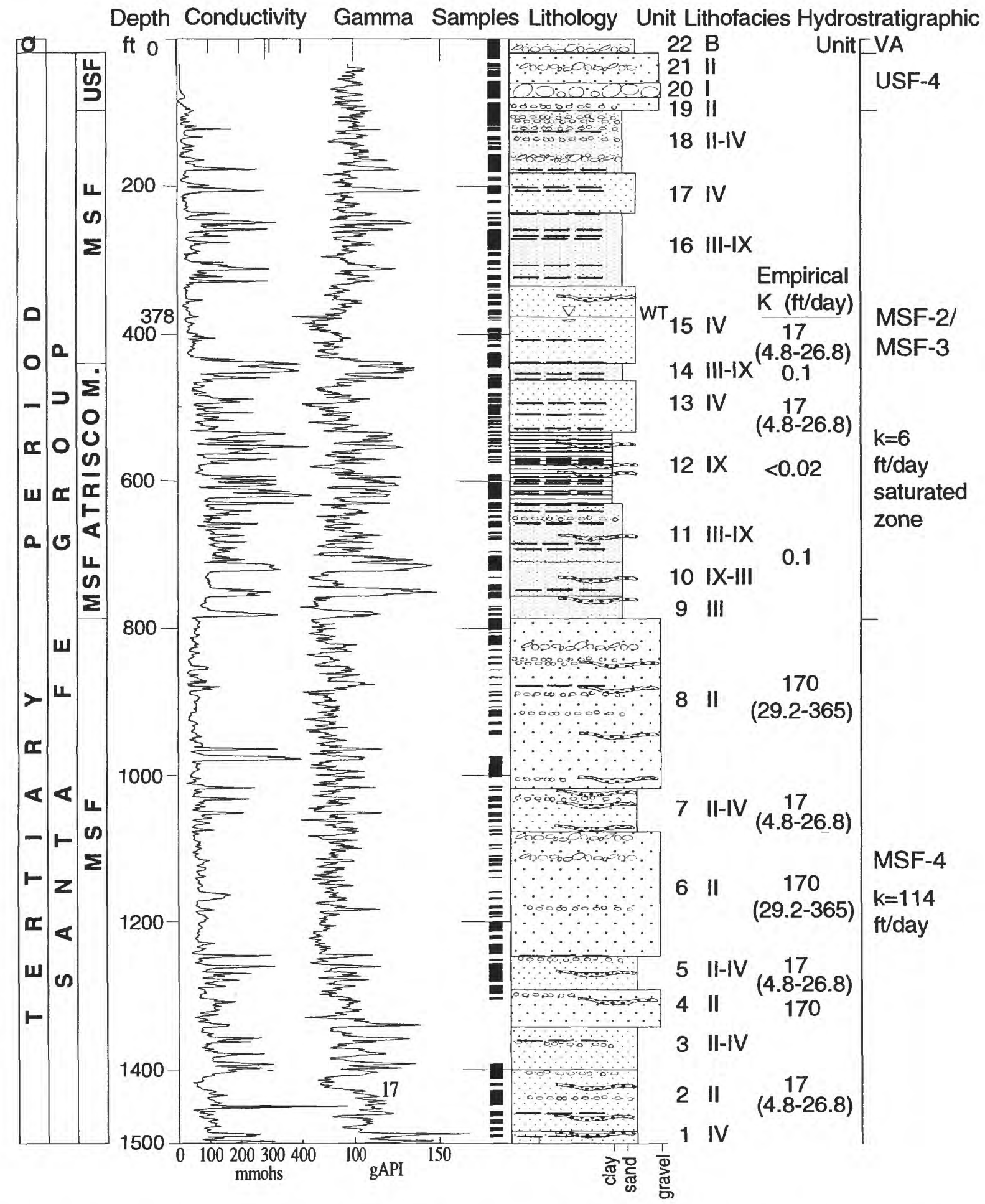

Figure 8. Stratigraphic framework of the $98^{\text {th }}$ Street core-hole site. WT, water table; $\mathrm{Q}, \mathrm{Quaternary}$ period; USF, upper unit of the Santa Fe Group; MSF, middle unit of the Santa Fe Group; MSF Atrisco M., the Atrisco Member of the middle unit of the Santa Fe Group; VA, valley-border alluvial unit.

desiccated mud-flat polygons, eolian concentration of dried clay pellets, deltaic foreset strata, rippledrift cross laminations, or wave segregated and sorted sediment in wavy bedforms were observed.
The lower section of the middle Santa Fe unit, 787$1500 \mathrm{ft}$ depth, includes an upper and a lower sequence. The upper sequence consists of moderately sorted, channel-fill medium sand, derived from 


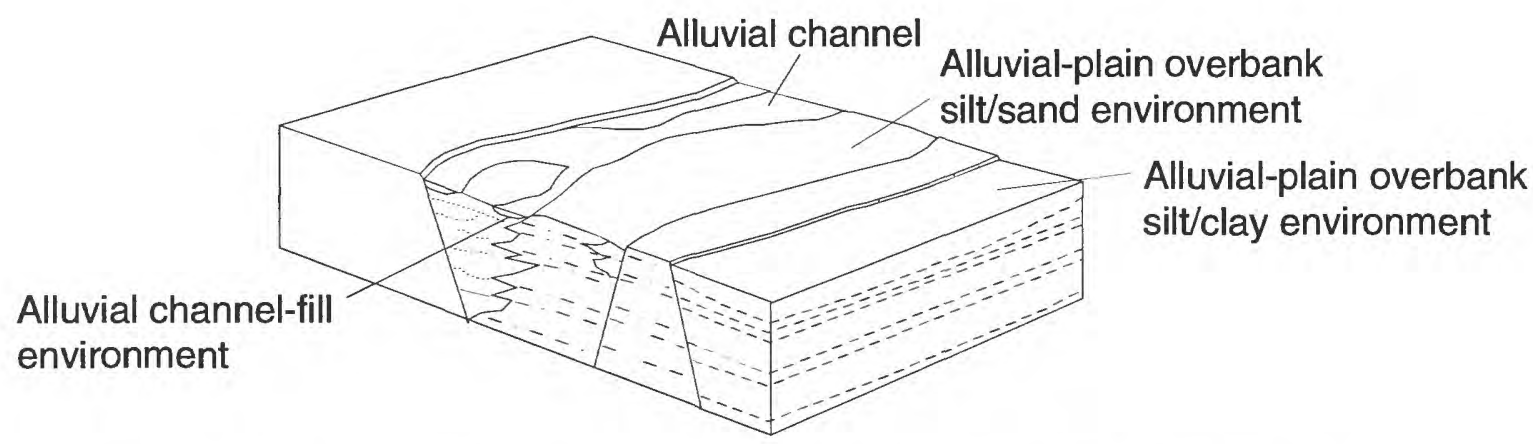

Figure 9. Depositional environments for three prominent lithofacies in a faulted alluvial-plain setting.

northeastern and northern fluvial source areas, and the lower sequence consists of sand and interbedded silt and clay overbank deposits.

We base the age of the cored interval of the Santa $\mathrm{Fe}$ Group on paleomagnetism and correlation to dated sections. The fluvial gravel beds of the upper Santa Fe unit regionally are related to establishment of an integrated, through-flowing river system in the Rio Grande rift system in Early Pliocene time, 4.5 Ma (Lozinsky and others, 1991; Chapin and Cather, 1994). We use regional correlation and preliminary paleomagnetic data to estimate the age of the middle Santa Fe Group. At Loma Colorado, $13.7 \mathrm{mi}$. (22 $\mathrm{km}$ ) north-northeast of the $98^{\text {th }}$ Street site, sandy light-brown and reddish-brown beds that directly underlie gravel deposits of the upper Santa Fe unit (S.F. Personius, USGS, pers. communication, 1997) reportedly are of Late Miocene (Hemphillian) age (R.H. Tedford, pers. communication, 1997), 4.6-8.9 Ma (Woodburne and Swisher, 1995). Paleomagnetic data from the $9^{\text {th }}$ Street core (Hudson and others, 1998) indicate that the middle Santa Fe unit, below $97 \mathrm{ft}$, is dominantly normal magnetic polarity. This section may correlate with closely-spaced normal magnetic chrons, 5.9-8.3 $\mathrm{Ma}$ in age (chrons C3An.1n-C4r.1n; Berggren and others, 1995), or with older normal chrons. The entire cored interval may span only a few million years.

We identified 22 lithologic units in the cored interval based on detailed examination of core samples and geophysical logs (Fig. 8). Beds with similar grain size, sedimentary structure, and composition characterize the lithologic units. We relate lithologic units to genetic lithofacies of the Middle Rio Grande Basin established by Hawley and others (1995; and Hawley, 1996). The lithofacies have characteristic geophysical-log signatures and lithic parameters that affect ground-water production
(Fig. 10; Haase and Lozinsky, 1992; Connell and others, 1998).

In the $98^{\text {th }}$ Street area, the upper Santa Fe Group beds represent basin-floor fluvial lithofacies comprising sand and gravel (lithofacies I), and alluvial channel-fill sand facies, consisting of sand with lenses of pebbly sand, silt, and silty clay (lithofacies II). The upper part of the middle Santa Fe Group contains interbedded sand, silt, and silty clay (modified lithofacies III, IV, IX) that were presumably deposited in overbank environments. Alluvial channel-fill sand facies with thin zones of overbank deposits compose the lower part of the middle Santa Fe unit. We summarize characteristics of three of these prominent lithofacies below.

Lithofacies III: Basin-floor alluvial, local lacustrine, and eolian interbedded sand, silt, silty clay (unit 16, 237-336 $\mathrm{ft}$ depth). Unit consists of interbedded thin beds of clayey and sandy silt, silty fine sand, brown (7.5YR $5 / 4)$ silty clay, red (2.5YR $4 / 6)$ to reddish brown (2.5-5YR 5/4) clay, and scattered beds of medium sand. Gamma and conductivity logs are characterized by highly variable baselines with prominent spikes that are related to clay beds and to interbedded sequences of silt, clay, and sorted fine sand. In these logs, clay beds $>0.2 \mathrm{ft}(6 \mathrm{~cm})$ thick are characterized by narrow-single, or broad-compound, highamplitude spikes. Thick clay beds, $>1 \mathrm{ft}(30 \mathrm{~cm})$ thick in the 237-264 ft-depth interval, are characteristically red to reddish brown, medium to high plasticity, massive to indistinctly microlaminated. Density of clay beds, and sandy silt and sand beds is similar $(2.12-2.25 \mathrm{~g} / \mathrm{cc})$. Porosity, however, is greater for clay beds $(>45 \%)$ than for sandy silt and sand beds (30-40\%). Depositional environments probably were fluvial inter-channel overbank areas, small secondary stream channels, and ponded areas. 


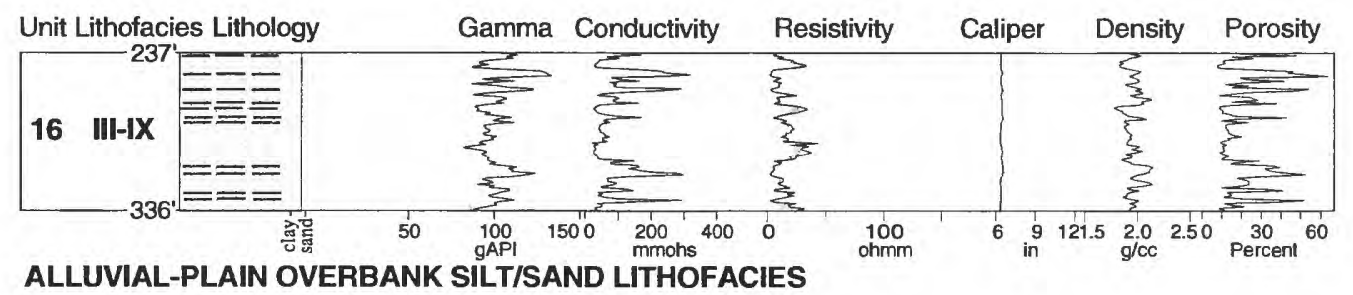

ALLUVIAL-PLAIN OVERBANK SILT/SAND LITHOFACIES

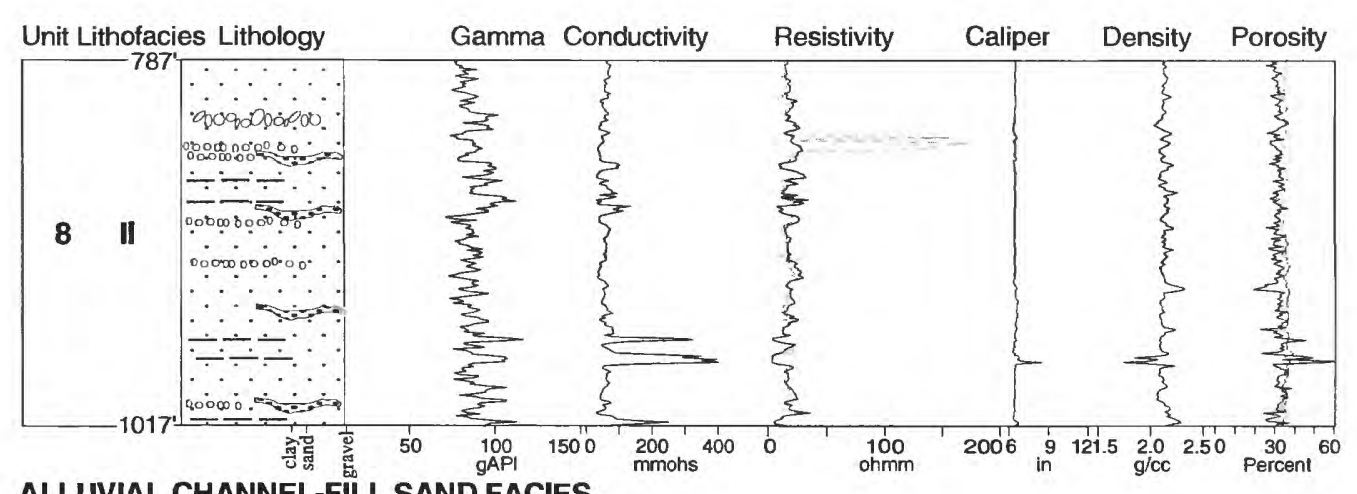

ALLUVIAL CHANNEL-FILL SAND FACIES

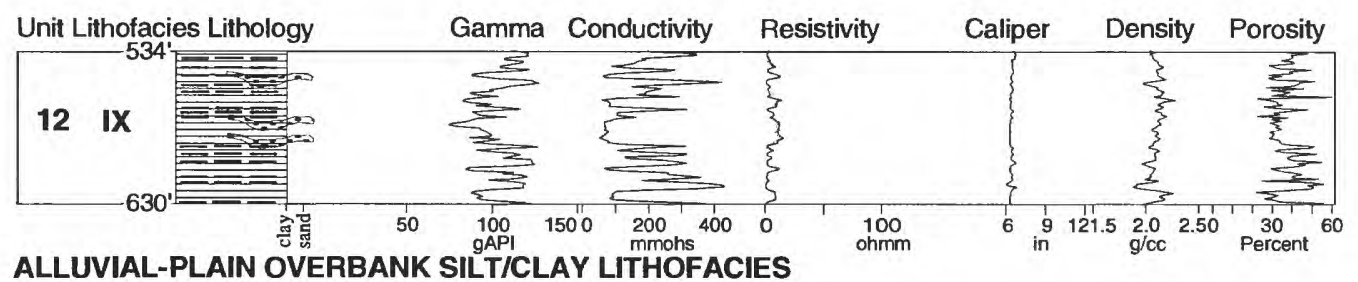

Figure 10. Lithology and geophysical logs for three prominent lithofacies of the $98^{\text {th }}$ Street core.

Lithofacies II: Basin-floor fluvial sand, lenses of pebbly sand, silt, and silty clay (unit 8, 787-1017 ft depth). Unit consists of gray (10YR 6/3-4/4) to light brown (7.5YR 6-5/4), fine to medium, moderately to poorly sorted sand and silty sand with coarse sand layers, scattered granules, and pebbles. Framework pebble gravel was recovered near 825-, 833-, 843-, and $860-\mathrm{ft}$ depths. Thin silty clay and clay interbeds, $<1 \mathrm{ft}(30 \mathrm{~cm})$ thick, were sampled in the $850-$ $880-\mathrm{ft}$ depth interval and near $978 \mathrm{ft}$. In gamma and conductivity logs, baselines of low values and low variability characterize medium sand. Deflections in gamma, conductivity, and porosity logs show vertical variability in 2-4- $\mathrm{ft}(0.6-1.2 \mathrm{~m})$ lengths, which are related to interbedded sequences of silt, clay, and sorted fine sand beds within the sand. Scattered, thin clay beds, $>0.2 \mathrm{ft}(6 \mathrm{~cm})$ thick, produce sharp, high-amplitude spikes. Thin, silty clay beds produce low-amplitude spikes in both logs. Density values of $2.05-2.20 \mathrm{~g} / \mathrm{cc}$ and porosity values of 30-35 percent are typical for medium sand. Density values $>2.25 \mathrm{~g} / \mathrm{cc}$, along with low porosity values, are related to thin beds of sandstone. Likely depositional environments include fluvial secondary stream channels and overbank areas.

Lithofacies IX: Basin-floor alluvial flat and local lacustrine silty clay interbedded with silty sand, silty clay, and clay (unit 12, 534-630 ft depth). Unit consists of reddish-brown to brown (5-7.5YR 5/4-4/6) clay and silty clay with interbedded fine to medium silty sand. Clay beds are massive to indistinctly microlaminated, locally preserving delicate laminae of clay and silt. In gamma and conductivity logs, a variable baseline distributed around relatively high values characterizes the silty clay sequence. Deflections in gamma, conductivity, and porosity logs show vertical variability in 2-4 $\mathrm{ft}(0.6-1.2 \mathrm{~m})$ lengths, which are related to interbedded sequences of silt and fine sand beds within the clay. Ten-ft- (3$\mathrm{m}-$ ) thick zones of clay, composed of beds $>0.2-\mathrm{ft}$ (6$\mathrm{cm})$ thick, produce broad, high-amplitude compound spikes in both gamma and conductivity logs. Thin clay beds, or silty clay beds produce numerous low-amplitude spikes in both logs. Density values of $2.12-2.25 \mathrm{~g} / \mathrm{cc}$ and porosity values of $>45$ percent are typical for silty clay and clay. Extensive, fluvial 
overbank areas and secondary stream channels are the presumed depositional environments.

We summarize the hydrogeologic framework for the $98^{\text {th }}$ Street site using four hydrostratigraphic units that closely relate to the lithostratigraphic units and their included lithofacies (Fig. 8). Estimated average horizontal hydraulic conductivity $(\mathrm{K})$ values for lithologic units in the $98^{\text {th }}$ Street core hole were derived from the empirical relationships of permeability and grain size of non-cemented samples of the Santa Fe Group (Detmer, 1995). We estimate the ranges of values (in parentheses, Fig. 8) from the variability of data points in the original analysis (Fig. 3 in Detmer, 1995). We base the estimated $K$ values for hydrostratigraphic units on $K$ values of the included lithologic units, normalized to their proportional thickness in the hydrostratigraphic units. The empirical $\mathrm{K}$ values estimated from core samples reveal a previously unidentified contrast in hydraulic conductivity in the lowest-two hydrostratigraphic units. Correlating among nearby wells shows that the fine-grained deposits of the Atrisco Member of the middle Santa Fe unit extend throughout much of the Albuquerque metropolitan area. With an estimated hydraulic conductivity of $<0.02-17 \mathrm{ft} /$ day, the Atrisco Member acts as a laterally extensive barrier to vertical ground-water flow, separating the upper Santa Fe Group aquifer from the middle Santa Fe aquifer. The underlying unit comprises thick sequences of moderately sorted medium sand and is therefore a potential production zone of the aquifer that bears further investigation.

\section{REFERENCES}

Allen, B.D., Connell, S.D., Hawley, J.W., and Stone, B.D., 1998, Core drilling provides information about Santa Fe Group aquifer beneath Albuquerque's west side: New Mexico Geology, v. 20, p. 8-13.

Berggren, W.A., Kent, D.V., Swisher, C.C., III, and Aubrey, M.P., 1995, A revised Cenozoic geochronology and chronostratigraphy: Society for Sedimentary Geology (SEPM) Special Publication No. 54, p. 130-212.

Chapin, C.E., and Cather, S.M., 1994, Tectonic setting of the axial basins of the northern and central Rio Grande Basin, New Mexico, in G.R. Keller and S.M. Cather (eds.), Basins of the Rio Grande Rift-Structure, stratigraphy, and tectonic setting: Geological Society of America Special Paper 291, p. 5-25.

Connell, S.D., Allen, B.D., and Hawley, J.W., 1998, Subsurface stratigraphy of the Santa Fe Group from borehole geophysical logs, Albuquerque area, New Mexico: New Mexico Geology, v. 20, p. 2-7.

Detmer, D.M., 1995, Permeability, porosity, and grain-size distribution of selected Pliocene and Quaternary sediments in the Albuquerque Basin: New Mexico Geology, v. 17, p. 79-87.

Haase, C.S., and Lozinsky, R.P., 1992, Estimation of hydrologic parameters, in J.W. Hawley and C.S. Haase (compilers), Hydrogeologic framework of the northern Albuquerque basin: New Mexico Bureau of Mines and Mineral Resources, Open-File Report 387, p. VI-1-VI-3.

Haneberg, W.C., Gomez, P., Gibson, A., and Allred, B., 1998, Preliminary measurements of stress-dependent hydraulic conductivity of Santa Fe Group aquifer system sediments from the 98th Street core hole, Albuquerque, New Mexico: New Mexico Geology, v. 20, p. 14-20.

Hawley, J.W., 1996, Hydrologic framework of potential recharge areas in the Albuquerque basin, central New Mexico, in J.W. Hawley and T.M. Whitworth (eds.), Hydrology of potential recharge areas and hydrogeochemical modeling of proposed artificial-recharge methods in basin- and valley-fill aquifer systems, Albuquerque Basin New Mexico: New Mexico Bureau of Mines and Mineral Resources Open-File Report 402-D, Chapter 1, p. 1-71.

Hawley, J.W., Haase, C.S., and Lozinsky, R.P., 1995, Hydrogeologic framework of the northern Albuquerque Basin, in Ortega-Klett (ed.), The water future of Albuquerque and Middle Rio Grande Basin: New Mexico Water Resources Research Institute, Technical Report No. 290, p. 37-55.

Hudson, Mark, Mikolas, Marlo, Allen, B.D., and Geissman, J.W., 1998, Paleomagnetic and rock magnetic studies of the upper Santa Fe Group; goals and preliminary results, in J.L. Slate (ed.), U.S. Geological Survey Middle Rio Grande Basin Study—Proceedings of the second annual workshop, Albuquerque, New Mexico, February 10-11, 1998: U.S. Geological Survey Open-File Report 98-337.

Kelley, V.C., 1977, Geology of Albuquerque basin, New Mexico: New Mexico Bureau of Mines and Mineral Resources Memoir 33, $60 \mathrm{p}$.

Lozinsky, R.P., Hawley, J.W., and Love, D.W., 1991, Geologic overview and Pliocene-Quaternary history of the Albuquerque Basin: New Mexico Bureau of Mines and Mineral Resources, Bulletin 137, p. 157-162.

Machette, M.N., 1978, Geologic map of the San Acacia quadrangle: U.S. Geological Survey Geologic Quadrangle Map GQ-1415, scale 1:24,000.

Munsell, 1975, Soil Color Charts: Munsell, Inc., Baltimore, MD, 22 p. 
Woodburne, M.O., and Swisher, C.C., III, 1995, Land mammal high-resolution geochronology, intercontinental overland dispersals, sea level, climate, and vicariance: Society for Sedimentary Geology (SEPM) Special Publication No. 54, p. 335-364.

\title{
PALEOMAGNETIC AND ROCK MAGNETIC STUDIES OF THE UPPER SANTA FE GROUP: GOALS AND PRELIMINARY RESULTS
}

\author{
M.R. Hudson ${ }^{1}$, Marlo Mikolas ${ }^{2}$, B.D. Allen ${ }^{3}$, and J.W. Geissman ${ }^{2}$ \\ ${ }^{1}$ U.S. Geological Survey, National Cooperative Geologic Mapping Team, \\ Box 25046, MS 913, Denver, CO 80225 \\ ${ }^{2}$ Dept. Earth and Planetary Sciences, Univ. of New Mexico, Albuquerque, NM 87131 \\ ${ }^{3}$ New Mexico Bureau of Mines and Mineral Resources, \\ 2808 Central Ave., S.E., Albuquerque, NM 87106
}

Paleomagnetic and rock magnetic studies of the upper part of the rift-filling Santa Fe Group within the Albuquerque Basin were initiated in the fall of 1996 with two principal goals: (1) to provide magnetostratigraphic information on the age and duration of sedimentation for key stratigraphic sections; and (2) to constrain the role of Santa Fe Group sediments as a magnetic source for aeromagnetic anomalies. Initial study has concentrated on samples collected over the $457-\mathrm{m}$ depth of the $98^{\text {th }} \mathrm{St}$. Core from the west side of Albuquerque. A 33-mthick surface section near Belen provides further information.

In magnetostratigraphy, we correlate normal and reverse magnetic-polarity zones within the stratigraphic interval to a geomagnetic polarity time scale (GPTS) to determine age. For the $98^{\text {th }}$ St. Core, about 200 samples distributed throughout the core length have been subjected to alternating-field demagnetization to identify magnetic components and to determine their polarity. A magnetic mineral having moderate coercivity, probably magnetite, carries the principal component of magnetization throughout the $98^{\text {th }}$ St. Core interval, despite a red coloration and the presence of a high-coercivity hematite component in some intervals. The magnetite component is dominantly of normal polarity, but samples with reverse polarity cluster at different depths throughout the section. We identified nine alternating normal- and reverse-polarity zones, defined by at least two samples of consecutive polarity, within the core. Assuming that the magnetite component was acquired at deposition, comparison of the multiple-polarity intervals to the GPTS sug- gests that deposition for the core interval spans at least 1 m.y. and probably 2-3 m.y. Nonetheless, further work on samples from additional depths and a more complete assessment of magnetic mineralogy and the mechanisms of remanence acquisition are needed before an exact correlation to the GPTS can be confidently proposed.

Numerous linear anomalies identified in recent high-resolution aeromagnetic surveys of the Albuquerque Basin are probably related to offset or alteration along faults within the Santa Fe Group (Grauch, this volume). Variation of magnetic properties with lithology within the Santa Fe Group gives insight into potential contrasts of total magnetization that controls the aeromagnetic expression of these rocks. Total magnetization of rocks is the vector sum of their induced magnetization, the product of the magnetic field and magnetic susceptibility (MS), and their natural remanent magnetization (NRM). Within the $98^{\text {th }} \mathrm{St}$. Core, MS varies over three orders of magnitude, both in logs of whole-core MS $\left(8.3 \times 10^{-2}\right.$ to $\left.1.1 \times 10^{-4} \mathrm{SI}\right)$ and in individual samples extracted from the core $\left(2.7 \times 10^{-2}\right.$ to $3.1 \times 10^{-5} \mathrm{SI}$. MS generally correlates with grain size such that the coarsest grained rocks have highest MS values. A similar variation of MS versus grain size is observed in the surface section near Belen where axial-facies conglomerates have ten-fold greater MS values $\left(1.7 \times 10^{-3} \mathrm{SI}\right)$ than claystone horizons $\left(2.0 \times 10^{-4} \mathrm{SI}\right)$. NRM values in both sections show similar yet less pronounced correlation with grain size. Calculations of total magnetization from the NRM and MS values illustrate that induced magnetization predominates over remanent mag- 
netization in all but the finest and least magnetic of Santa Fe Group sediments. These data suggest that coarse-grained aquifer rocks have highest total magnetization and thus greatest potential for gen- eration of aeromagnetic anomalies where juxtaposed with fine sediments or where altered by fluids channeled along faults.

\title{
REFERENCES
}

Grauch, V.J.S., 1998, Expression of faults in high-resolution aeromagnetic data near Albuquerque, New Mexico--preliminary results, in Slate, J.L., (ed.), U.S. Geological Survey Middle Rio Grande Basin Study-Proceedings of the second annual workshop, Albuquerque, New Mexico, February 10-12, 1998: U.S. Geological Survey Open-File Report 98-337.

\section{SEDIMENT AND GROUND-WATER GEOCHEMISTRY OF THE $98^{\text {TH }}$ ST. DRILL CORE NEAR ALBUQUERQUE, NEW MEXICO}

\author{
Mark R. Stanton, David J. Grimes, Richard F. Sanzolone, and Steven S. Sutley \\ U. S. Geological Survey, Mineral Resources Team, \\ Box 25046, MS 964, Denver, CO 80225
}

Most major elements and trace metals exhibit similar abundance patterns with depth and within a given lithologic unit in samples from the $98^{\text {th }} \mathrm{St}$. drill core on the west side of Albuquerque. The greatest amount of most trace metals, in particular arsenic (As) and iron ( $\mathrm{Fe}$ ), is associated with finergrained materials (fine sand, silt, and clay). We used ICP-AES (inductively coupled plasma - atomic emission spectrometry) and ICP-MS (inductively coupled plasma - mass spectrometry) to analyze sediment samples.

Bulk-sample X-ray diffraction (XRD) methods have identified: (1) major amounts of quartz; (2) varying amounts of orthoclase, albite, and sanidine, and other aluminosilicates, such as muscovite; (3) carbonates including major calcite and minor dolomite; and (4) only remnants of sulfides (possibly pyrite). We also used XRD to examine 15 clay separates; the dominant clay minerals include illite, smectite, mixed-layer illite/smectite, and kaolinite. Scanning-electron microscope (SEM) analyses of high As-bearing sediments ( $>10$ parts per million [ppm]) indicate that increased amounts of As are generally associated with increased levels of Fe (primarily as Fe-oxides). Arsenic concentrations in discrete core samples taken at 1-ft intervals from $655-765 \mathrm{ft}$ range from 2 to $25 \mathrm{ppm}$ on a dry-weight basis. Arsenic is at least twice its crustal abundance value (1.8 ppm) in 47 of the 60 discrete samples. Iron in these high As-bearing samples ranges from 3-4 wt. percent; in lower-As samples ( $\leq 10 \mathrm{ppm}), \mathrm{Fe}$ is $2.5 \mathrm{wt}$. percent or less.

Concentrations of total dissolved arsenic $\left(\mathrm{As}_{\mathrm{tot}}\right)$ in ground-water samples are as follows:

\begin{tabular}{ccc}
\hline $\begin{array}{c}\text { Depth } \\
(\mathrm{ft})\end{array}$ & $\begin{array}{c}\mathrm{As} s_{\text {tot }} \\
\mu \mathrm{g} / \mathrm{L} \\
(\mathrm{ppb})\end{array}$ & Dominant As Species \\
\hline 438 & 16 & $\mathrm{As}^{5+}\left(\geq 90 \%\right.$ of $\left.A s_{\text {tot }}\right)$ \\
749 & 7 & $\mathrm{As}^{3+}\left(\geq 66 \%\right.$ of $\left.A s_{\text {tot }}\right)$ \\
1112 & 30 & $\mathrm{As}^{3+}\left(\geq 66 \%\right.$ of $\left.A s_{\text {tot }}\right)$ \\
1544 & 34 & $\mathrm{As}^{5+}\left(\geq 90 \%\right.$ of $\left.\mathrm{As} s_{\text {tot }}\right)$ \\
\hline
\end{tabular}

The two-highest solid-phase As concentrations (23 ppm at $723 \mathrm{ft}$, and 25 ppm at $759 \mathrm{ft}$ ) bracket the 749 $\mathrm{ft}$ ground-water sample; yet aqueous $\mathrm{As}_{\text {tot }}$ in the 749 - $\mathrm{ft}$ interval is the lowest $(7 \mu \mathrm{g} / \mathrm{L})$ of the four ground waters sampled. The low $\mathrm{As}_{\text {tot }}$ concentration in the aqueous sample suggests As is less readily solubilized from these two dominantly fine-sand sediments. That is, although most arsenic is present as "mobile" $\mathrm{As}^{3+}$, the total aqueous arsenic concentration is low relative to solid-phase arsenic that is potentially available for dissolution. The two, high As-bearing sediments, however, may not be hydraulically connected with the ground water that 
was sampled. The short screened interval (5 feet, from 739-744 ft) may inhibit ground water input from the high-As sediments, especially if impermeable layers are present above or below the screened interval.

In contrast to the fine-grained sand, mediumgrained sand with relatively low solid-phase As ( $\leq 4$ ppm) bracket the 1112-ft ground-water sample, but this sample has the second-highest aqueous $A s_{\text {tot }}$ concentration $(30 \mu \mathrm{g} / \mathrm{L})$. The screened interval is from $1102-1107 \mathrm{ft}$, and $\mathrm{As}^{3+}$ is again dominant in the ground water. In the other two groundwater samples, $\mathrm{As}^{5+}$ is the dominant dissolved As species. These contrasts in As tot concentrations from solidphase and aqueous samples suggest that As is more readily solubilized from dominantly medium-sand sediments than from dominantly fine-sand sediments.
The results also illustrate that As solubility is variable within different sample intervals. Because arsenic solubility is generally enhanced as $\mathrm{pH}$ increases above 7.0, the variable proportions of $\mathrm{As}^{3+}$ and $\mathrm{As}^{5+}$ from waters having high $\mathrm{pH}$ (8.4-9.9) suggest that local redox conditions exert strong control on As mobility in ground water. We speculate that the strong association of $\mathrm{Fe}$ and As in high-As sediments is the result of As complexation and adsorption on Fe-oxides or Fe-oxide coatings on mineral surfaces.

Further work includes partial extraction methods and additional SEM analyses to determine the mineral residences of arsenic in the core samples. Geochemical modeling is also underway to further define the impact of local ground-water chemistry on the mobility of As in the sediments. 


\title{
Recharge/Infiltration \& Hydraulic Characteristics
}

\section{EFFECTS OF BASIN-MARGIN STRUCTURE AND STRATIGRAPHY ON GROUND-WATER RECHARGE IN THE PLACITAS AREA, NORTHERN ALBUQUERQUE BASIN, NEW MEXICO}

\author{
Peggy Johnson ${ }^{1}$, William LeFevre ${ }^{2}$, Andrew Campbell ${ }^{2}$, and Brian McPherson ${ }^{2}$ \\ ${ }^{1}$ New Mexico Bureau of Mines and Mineral Resources, 801 Leroy Place, Socorro, NM 87801 \\ ${ }^{2}$ New Mexico Institute of Mining and Technology, Socorro, NM 87801
}

Preliminary data from a ground-water study in progress for Sandoval County by the New Mexico Bureau of Mines and Mineral Resources, indicate that faults in the Placitas area behave as both barriers to and conduits for ground-water flow into the northern Albuquerque basin. Placitas is located on the eastern margin of the Albuquerque Basin, at the northern termination of the Sandia uplift, northeast of Albuquerque. Major west-dipping, rift-margin, normal faults, including the San Francisco-Placitas fault zone and numerous subsidiary faults, cut north-dipping Paleozoic and Mesozoic sedimentary strata as they ramp below Santa Fe Group basin fill. Ground water in this structurally and stratigraphically complex setting exists in a compartmentalized aquifer system that is recharged through a combination of surface-water and preferential groundwater flow paths originating in the Sandia Mountains to the south. Piezometric data from private wells, preliminary stable-isotope, ionic and traceelement data from ground and surface water, and surface and subsurface geologic data indicate the existence of an assortment of confined and unconfined aquifers with a wide range of water quality and productivity, and varying degrees of hydraulic interconnection. Piezometric data in the vicinity of the Placitas and San Francisco faults generally indicate dramatic declines in fluid potential of 200 to 300 feet across these structures. Numerous springs discharge on the up-gradient sides of the faults indicating that the faults attenuate ground-water flow along most of their extent. Relatively gradual hydraulic gradients do occur across the faults at isolated locations, however, pointing to the existence of preferential flow paths and/or recharge zones that channel ground-water flow into the Albuquerque basin.

Stable-isotope data from ground water, surface water, and spring discharge are interpreted relative to a local meteoric water line defined from a network of precipitation collectors located along the north slope of the Sandia Mountains. Variations in ground-water stable-isotope ratios ( $\delta \mathrm{D}$ of $-119 \%$ o to $-87 \%$ ond $\delta^{18} \mathrm{O}$ of $-15.0 \%$ o to $-11.4 \%$ ) appear to spatially correlate to recharge signatures from precipitation and surface-water sources. Isolated regions of anomalously light stable isotope ratios $\left(-119\right.$ to $-115 \%$ o $\mathrm{D}$ and -15.0 to $\left.-13.6 \%{ }^{18} 0\right)$, are interpreted to represent areas of paleowater in isolated portions of the Santa Fe Group aquifer.

Chemical analyses of mountain-front spring water along the San Francisco-Placitas fault zone suggest a common source of calcium-bicarbonate ground water originating in the Madera Group limestone (Pennsylvanian). Ground water from the Santa Fe Group aquifer immediately down gradient of the San Francisco fault is chemically similar to that of the springs and the Madera aquifer wells. A significant change in general and trace-element chemistry is detected in ground waters discharging from the Mesozoic-age sediments adjacent to the Placitas fault zone. These ground waters exhibit very high concentrations of sodium ( $\leq 1450 \mathrm{ppm})$, sulfate ( $\leq 3900 \mathrm{ppm})$, and dissolved solids ( $\leq 5950 \mathrm{ppm})$, and elevated concentrations of iron $(\leq 940 \mathrm{ppb})$, copper $(\leq 270 \mathrm{ppb})$, manganese $(\leq 370 \mathrm{ppb})$, and zinc $(\leq 110$ $\mathrm{ppb}$ ). Low concentrations of arsenic ( 5 to $21 \mathrm{ppb}$ ) are generally characteristic of ground water discharging from both the Triassic age Agua Zarca and lower Petrified Forest Formations, as well as certain areas of the Santa Fe Group aquifer. These high TDS, sodium-sulfate ground waters are interpreted to reflect "long" residence times under semiconfined conditions in low permeability Mesozoicage sediments that are isolated from direct sources of recharge.

Together these various data support a complex pattern of recharge to the aquifers adjacent to and down-gradient of the San Francisco-Placitas fault 
zone. Recharge appears to be moving through the Madera limestone and across the fault zones via preferential pathways, and is also being redistributed into the aquifers as line sources of infiltrating surface water originating from spring discharge and stream flow. Neither piezometric data nor variations in ionic, trace-element, or stable-isotope chemistry support a spring-discharge origin from an alternate, deep-basin source of ground water that flows vertically upward in the faults. Additional ground-water sampling for age determination will be undertaken to test this regional hydrogeologic conceptual model.

\title{
TEMPERATURE PROFILES OF THE AQUIFER SYSTEM UNDERLYING THE RIO GRANDE, MIDDLE RIO GRANDE BASIN, NEW MEXICO-SECOND-YEAR STATUS
}

\author{
James R. Bartolino \\ U.S. Geological Survey, Water Resources Division, \\ 4501 Indian School Road, N.E., Suite 200, Albuquerque, NM 87110
}

An important gap in the understanding of the hydrology of the Middle Rio Grande Basin, central New Mexico, is the rate at which water from the Rio Grande recharges the Santa Fe Group aquifer system. The New Mexico State Engineer Office currently (1997) uses the methods of Glover and Balmer (1954) to estimate the rate of recharge. Results of a numerical model of the Albuquerque Basin (Kernodle and others, 1995) indicate that the Glover-Balmer equations overestimate the volume of water recharged from the river during the 190194 period of simulation. This article describes the plan and second-year progress of a study whose purpose is to determine the vertical hydraulic conductivity of the Santa Fe Group aquifer system that underlies the Rio Grande. The U.S. Geological Survey plans to use this information in conjunction with the Albuquerque Basin model to refine the estimates of recharge from the Rio Grande. This study uses piezometer-core and temperature-profile data to model the distribution of vertical hydraulic conductivity (Lapham, 1989) underlying the Rio Grande inner-valley alluvium.

Seven sets of nested piezometers were installed during July and August 1996 at four sites along the Rio Grande in the Albuquerque area (Fig. 11). In downstream order, these sites are: (1) the Bernalillo site, upstream from the State Highway 44 bridge in Bernalillo (BRN01 and BRN02); (2) the Corrales site, upstream from the Rio Rancho sewage treatment plant in Corrales (COR01 and COR02); (3) the Paseo del Norte site, upstream from the Paseo del Norte bridge in Albuquerque (PDN01 and PDN02); and (4) the Rio Bravo site, upstream from the Rio Bravo bridge in Albuquerque (RBR01). At each of the first three sites, one piezometer nest is located on the bank and the other nest is on a sandbar in the river channel. At Rio Bravo, the only nest was installed on the bank because of the lack of accessible sandbars. Except for the sandbar nest at Bernalillo, where two piezometers were installed at depths of 11 and $17 \mathrm{ft}$, three piezometers were installed in each nest at depths ranging from 8 to $50 \mathrm{ft}$. All piezometers were completed in river valley alluvium of the Santa Fe Group aquifer system. During installation, a core was collected at each nest. Daniel B. Stephens and Associates analyzed 11 sediment samples representing the most representative texture(s) from these cores for initial moisture content (gravimetric and volumetric), dry-bulk density, initial wet-bulk density, and porosity.

Five times between September 1996 (the month of anticipated warmest ground-water temperatures) and April 1997, temperature profiles were measured in the deepest piezometer in each nest and water levels were measured in all piezometers. At the same time, temperatures were logged in existing 150-ft piezometers at the Paseo del Norte and Rio Bravo sites to confirm results of measurements collected from the shallow piezometers.

Figure 12 shows ground-water temperature profiles for the COR02 and PDN01 piezometer nests located on sandbars near the west riverbank. Although 


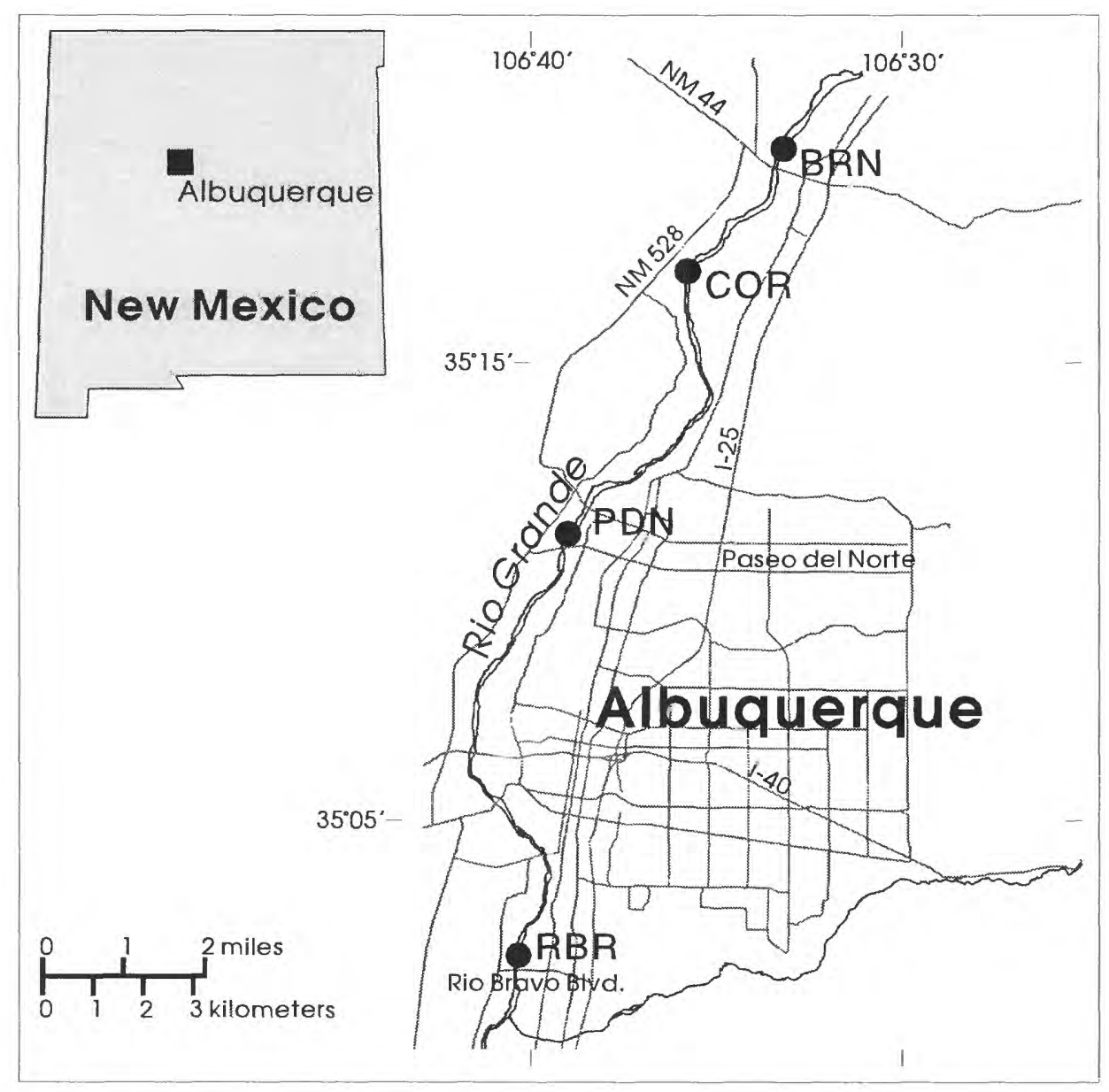

Figure 11. Location map of the Albuquerque area showing locations of the temperature profile sites. BRN, Bernalillo site; COR, Corrales site; PDN, Paseo del Norte site; RBR, Rio Bravo site.

temperatures were not logged continuously for an entire year, the approximate warmest and coldest temperatures presumably were measured.

The annual ground-water temperature fluctuations shown in the temperature profiles for COR02 and PDN01 are similar to other profiles measured for this study, to preliminary modeling results, and to profiles shown in Lapham (1989). In the plot for COR02, the ground water appears to approach a constant temperature near the bottom of the piezometer at approximately $35 \mathrm{ft}$. In the plot for PDN01, however, fluctuations of approximately $2^{\circ}$ Celsius are indicated for the water near the bottom of the piezometers at depths exceeding $50 \mathrm{ft}$. A deflection can be noted in all curves for PDN01 at a depth of approximately $17 \mathrm{ft}$. This deflection may result from a change in sediment texture, changes in the direction of ground-water flow, or changes in the source of ground-water recharge.

Models have been constructed of each of the seven piezometer nests using the VS2DH model of Healy and Ronan (1996). The models are being calibrated with the ground-water temperature and hydraulichead data collected from the seven sets of piezometers.

\section{REFERENCES}

Glover, R.E., and Balmer, C.G., 1954, River depletion resulting from pumping a well near a river: EOS, Transactions, American Geophysical Union, v. 35, no. 3, p. 468-470.

Healy, R.W., and Ronan, A.D., 1996, Documentation of computer program VS2DH for simulation of energy transport in variably saturated porous media-Modification of the U.S. Geological Survey's computer program VS2DT: U.S. Geological Survey Water-Resources Investigations Report 96-4230, 36 p. 

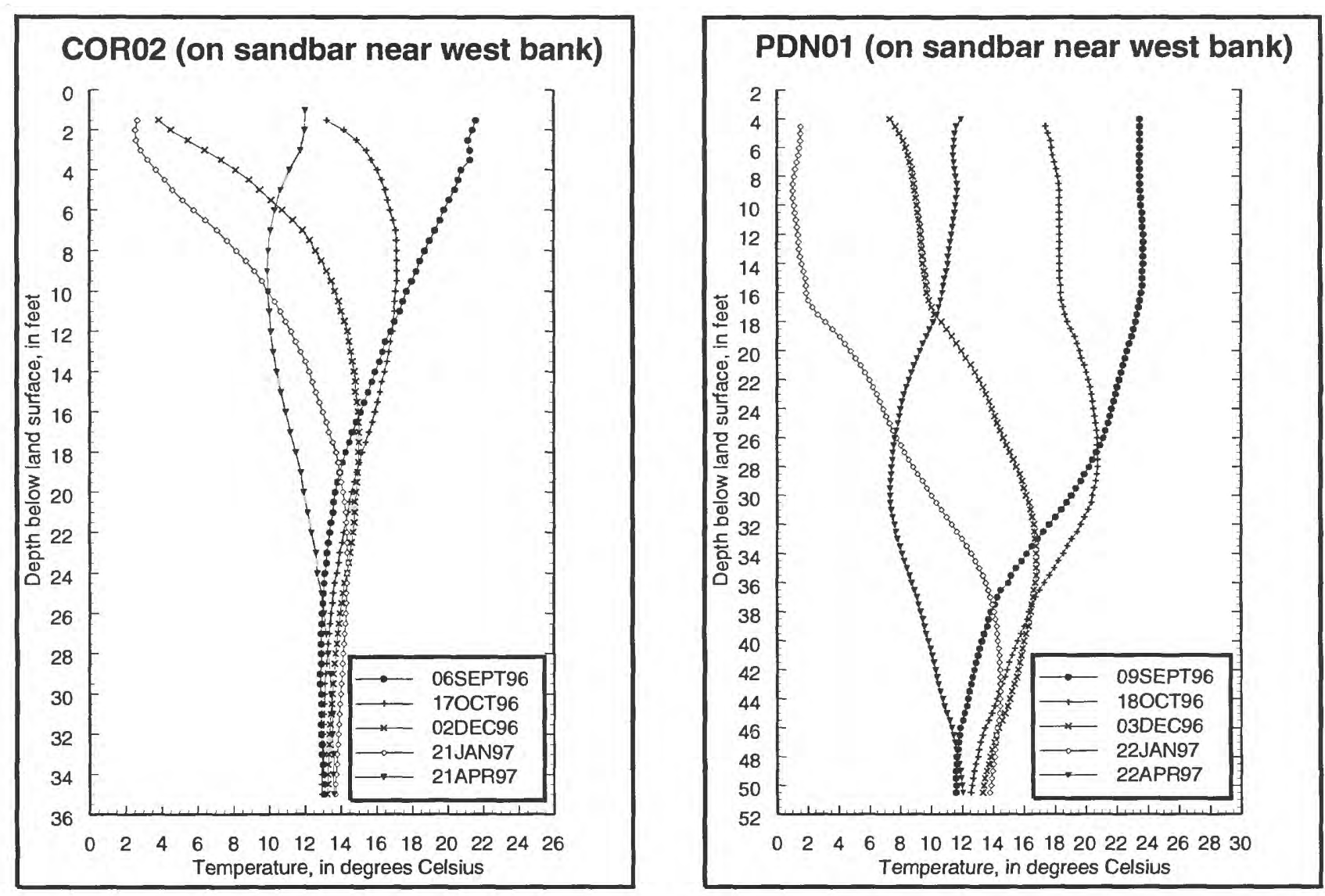

Figure 12. Ground-water temperature profiles drawn from data measured in Corrales piezometer COR02 and Paseo del Norte piezometer PDN01.

Kernodle, J.M., McAda, D.P., and Thorn, C.R., 1995, Simulation of ground-water flow in the Albuquerque Basin, central New Mexico, 1901-1994, with projections to 2020: U.S. Geological Survey Water-Resources Investigations Report 94-4251, 114 p., 1 pl.

Lapham, W.W., 1989, Use of temperature profiles beneath streams to determine rates of vertical ground-water flow and vertical hydraulic conductivity: U.S. Geological Survey Water-Supply Paper 2337, 35 p. 


\title{
USE OF SURFACE-WATER PULSES TO ESTIMATE HYDRAULIC CHARACTERISTICS OF THE RIO GRANDE ALLUVIUM, ALBUQUERQUE AREA, NEW MEXICO
}

\author{
D. Michael Roark \\ U.S. Geological Survey, Water Resources Division, \\ 4501 Indian School Road, N.E., Suite 200, Albuquerque, NM 87110
}

Ground water is the principle source of drinking water in the Albuquerque area (Thorn and others, 1993, p.1). As increasing amounts of ground water are pumped, water managers and others have raised questions about how much the Rio Grande recharges the surrounding aquifer. Because the amount of recharge is directly related to the aquifer characteristics of the surrounding alluvium (Thorn and others, 1993, p.53), the Bureau of Reclamation conducted a surface-water pulse study on the Rio Grande in the Albuquerque area in May 1997 to estimate hydraulic characteristics of the Rio Grande alluvium. The results of the study showed that a pulse, an approximate 1-foot increase in river stage, propagates from the river to the riverside drains, but is not distinguishable in ground-water wells beyond the drain (Bureau of Reclamation, 1995, p. 24). According to the Bureau of Reclamation (p. 24), "Another round of field work and data modeling, with better instrumentation and data-collection outcome, may prove useful to confirm these findings." McAda (1996, p. 48) further, suggested that, "It would be useful to conduct a similar experiment, using a flood pulse in the riverside drain rather than the river. This would allow propagation of the flood pulse to the alluvium beyond the drain."

The U.S. Geological Survey is conducting a project to estimate hydraulic characteristics of the alluvial aquifer (Rio Grande alluvium) adjacent to the Rio Grande and the associated drain near the Rio Bravo Bridge. These characteristics will be determined from results of short-duration and long-duration surface-water pulses in the river and drains that stress the ground-water system. The short-duration surface-water pulses will consist of one engineered pulse in the Rio Grande, several engineered pulses in the East Riverside Drain, and any storm-derived pulses in the river that occur during the datacollection period. An engineered pulse is a shortduration increase in river stage caused by water released from upstream reservoirs specifically for this study. The long-duration pulses will consist of the normal changes in river stage during the year. Long-duration pulses are useful because short- duration pulses might not stress the ground-water system enough to result in measurable groundwater-level changes away from the river and riverside drain.

Lithologic logs of existing piezometers at the Rio Bravo site were analyzed to determine the vertical distribution of confining layers and strata. Three new wells were installed after analysis of the logs to ensure a complete data set for analysis (Fig. 13). RBR2 is a three-well nest with well depths of 29,50 , and 150 feet. RBR5 is also a three-well nest with well depths of 35, 150, and 500 feet. Wells BOR1, BOR2, BOR3, RBR6, RBR7, and RBR8 are all shallow wells with a maximum depth of 15 feet. Slug tests were performed on all wells to ensure that the wells were in good hydraulic connection with the aquifer and to determine hydraulic conductivity ranges for the alluvium.

Pressure transducers were installed in all wells in the section to measure water-level changes. Pressure transducers and recorders were installed at two sites on the East Riverside Drain, and a stage/discharge relation was developed for each drain site by making streamflow measurements. The south drain-gage was near the wells to record drain stage; the north drain-gage was 3 miles upstream from the south drain-gage to determine the volume of water that the drain is gaining or losing. Streamflow data also were collected at the Rio Bravo streamflow gage.

Data were collected at all sites for a 5-month period (December 1996 to May 1997) to ensure adequate data availability for several short-duration and long-duration pulses. The 5-month time frame also allowed sufficient time to collect background data to determine which stresses were caused by the flood pulse and which were caused by outside influences such as ground-water pumping.

The U.S. Geological Survey, the Bureau of Reclamation, the U.S. Army Corps of Engineers, and the City of Albuquerque coordinated an engineered short- 


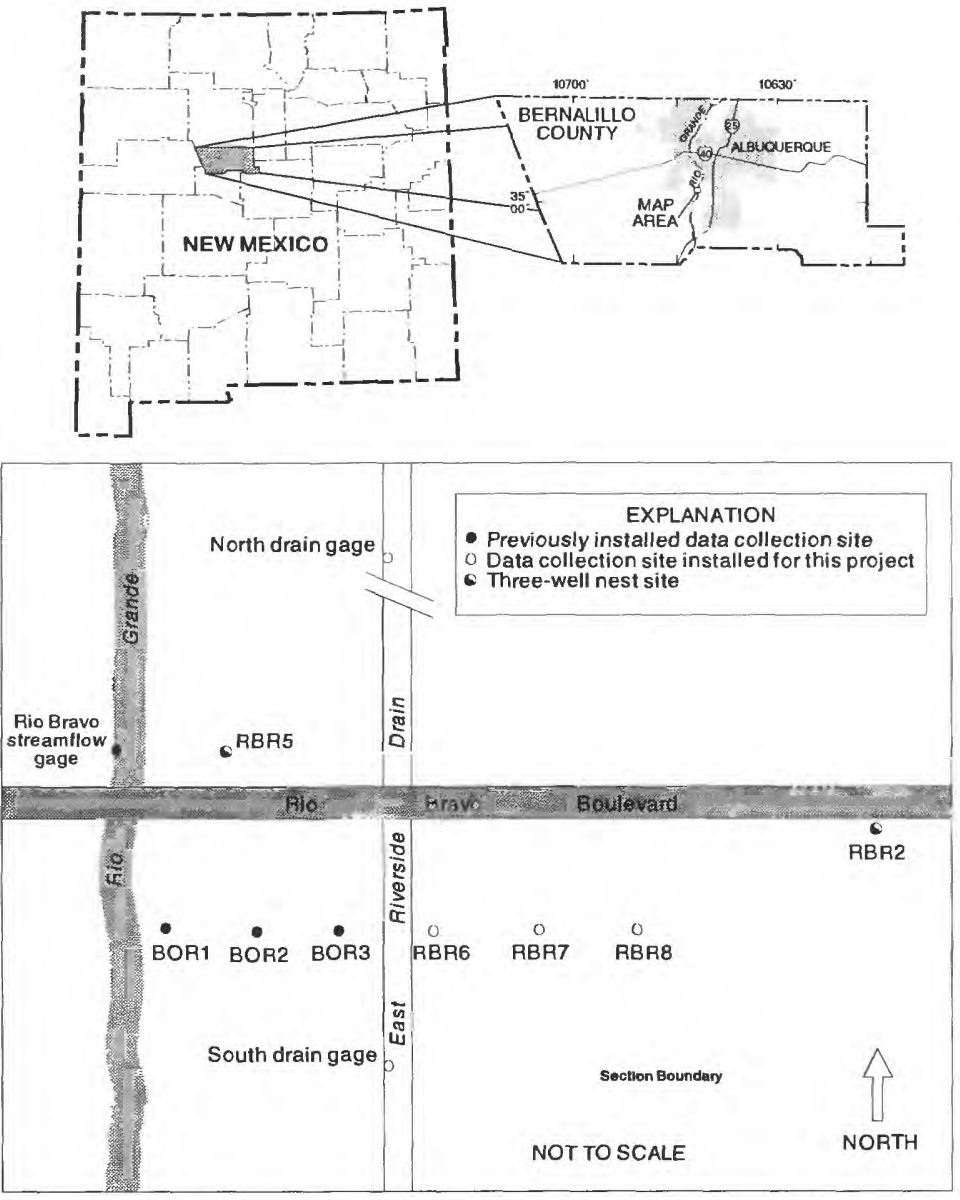

Figure 13. Map showing site locations, near Rio Bravo Boulevard in Albuquerque. duration pulse in the river in February 1997. February was selected to avoid interference from stresses such as canal leakage, irrigation-return flow, and evapotranspiration. Just before the beginning of the irrigation season in March, the Middle Rio Grande Conservancy District diverted water into the East Riverside Drain; this diversion served as a long-duration surface-water pulse.

To determine aquifer characteristics, a cross-sectional steady-state representation of the alluvial ground-water system is being constructed using the crosssectional model functionality of Modflow-96 (Harbaugh and McDonald, 1996). The layers of the model will represent the vertical distribution of strata determined from well logs. The aquifer-storage values determined from log analysis and the hydraulic-conductivity values determined from slug tests will be used as the initial conditions. Head-dependent flux boundaries will be used to represent the river and drains. Stresses of the surfacewater pulses will be simulated and aquifer characteristics will be determined using a transient-state model.

\section{REFERENCES}

Bureau of Reclamation, 1995, Flood wave test and transient groundwater analysis: Middle Rio Grande Water Assessment Technical Memorandum, Albuquerque Projects Office, variously paged.

Harbaugh, A.W., and McDonald, M.G., 1996, Users documentation for Modflow-96, an update to the U.S. Geological Survey modular finite-difference ground-water flow model: U.S. Geological Survey Open-File Report 96-485, 56 p.

McAda, D.P., 1996, Plan of study to quantify the hydrologic relations between the Rio Grande and the Sante Fe Group aquifer system near Albuquerque, central New Mexico: U.S. Geological Survey Water-Resources Investigations Report 96-4006, $58 \mathrm{p}$.

Thorn, C.R., McAda, D.P., and Kernodle, J.M., 1993, Geohydrologic framework and hydrologic conditions in the Albuquerque Basin, central New Mexico: U.S. Geological Survey Water-Resources Investigations Report 93-4149, 106 p. 


\title{
Recharge—Santa Fe River, Bear Canyon, Abo Arroyo Studies
}

\section{MEASUREMENTS OF TRIBUTARY, INTER-ARROYO, AND MOUNTAIN-FRONT RECHARGE ON THE SANTA FE RIVER, BEAR CANYON, AND ABO ARROYO, NEW MEXICO}

\author{
Jim Constantz \\ U.S. Geological Survey, Water Resources Division, Branch of Regional Research, \\ 345 Middlefield Road, MS 496, Menlo Park, CA 94025
}

Several research projects within the U.S. Geological Survey-Water Resources Division (WRD) are using a range of research techniques to estimate potential recharge rates along the eastern flank of the Middle Rio Grande Basin (MRGB). The goals of the projects are to: (1) provide estimates of streambed infiltration and potential recharge at specific locations for the daily to seasonal recharge period; (2) provide long-term estimates of recharge for the decade to century recharge period; and (3) compare recharge results generated from different techniques with respect to such parameters as mean values, ranges, and uncertainties. Research was initiated in FY96, some research will be completed in FY98, and other research will be completed in FY99 and FY00. An overview of the status of these research projects follows.

John Nimmo, Branch of Regional Research (BRR), Western Region (WR), WRD, and coworkers (in these proceedings) are using the steady-state centrifuge method (SSCM) to estimate long-term recharge rates at specific locations in the MRGB. Accurate measurement of unsaturated hydraulic conductivity (K) and soil moisture by the SSCM can indicate long-term average recharge rates (Nimmo and others, 1994). The steps required are as follows. (1) Obtain core samples from deep in the unsaturated zone such that moisture fluctuations are negligible. (2) Determine the total downward-driving force for water. In a homogeneous medium, at depths where moisture does not fluctuate, the flow is steady and driven only by gravity. In a layered profile, however, the likelihood and magnitude of significant matric-potential gradients must be evaluated with a Darcy-based analysis. In either case, Darcy's law can indicate the local recharge rate if $K$, at the water content existing at that depth, is known. (3) Measure $\mathrm{K}$ with the SSCM, which establishes a measurable steady flow of water in a centrifugal field as great as $2000 \mathrm{~g}$. This method is well suited for the required measurements because it gives accurate $K$ values in the low-water-content range important at arid and semiarid sites. Dave Stonestrom, BRR, WR, WRD, and Fred Gebhardt, New Mexico District (NM), WRD, collected core samples for the SSCM near the Santa Fe River at La Bajada, in Bear Canyon, and Abo Arroyo. Angus Lewis, BRR, WR, $W R D$, is currently determining $K$ values.

Stonestrom and coworkers (in these proceedings) collected bulk-soil samples at the same locations where core samples were collected for the SSCM. They are analyzing environmental tracers from these bulk samples to delineate spatial patterns of ground-water recharge and to estimate recharge magnitudes. Chloride and bromide concentrations are being determined by ion chromatography. These constituents are chemically conservative and can indicate local recharge, if assumptions about sources are satisfied. Pore waters extracted by cryodistillation are being analyzed for tritium, deuterium, and oxygen-18. Concentration peaks in the unsaturated zone profile provide estimates of rates of percolation and potential recharge on the decade time scale. The use of multiple environmental tracers overly constrains recharge estimates and provides an indication of their accuracy in determining long-term recharge in the vicinity of the sampling location.

Carole Thomas, NM, WRD, and coworkers (in these proceedings) established a series of stream gages on the La Bajada reach of the Santa Fe River to estimate streambed infiltration losses. She calculated streamflow from 15-minute stage measurements at each of three sites over a 2.5-kilometer $(\mathrm{km})$ reach to estimate streamflow differences between the gages for FY97. Numerous seepage runs were performed in June 1997 to accurately determine diurnal variations in streamflow. These results were used as a basis to estimate streambed-infiltration rates for comparison 
to the streambed-temperature profile (stp) method (Stewart and others, in these proceedings).

Amy Stewart, BRR, WR, WRD, and coworkers (in these proceedings) have been using a variety of thermal-tracking procedures (Constantz and Thomas, 1996, 1997; Ronan and others, 1997; Stewart and others, 1997) to estimate streamflow-loss patterns at the La Bajada reach of the Santa Fe River, at Bear Canyon, and in Abo Arroyo. They are investigating the stp method as a tool to estimate streambed percolation rates at each location. In addition, temperature patterns at Bear Canyon and Abo Arroyo are analyzed to determine whether temperature alone can be an indicator of streamflows at the site. A spatially distributed surface temperature procedure is being tested at 8 sites in a $30-\mathrm{km}$ reach in Abo Arroyo between the USGS gaging station and the Rio Grande. The procedure is designed to measure the timing-that is, presence or absence, and duration-of streamflow at specific locations with the study reach. Streamflow hydrographs from the gaging station will be compared to the spatial and temporal patterns of streambed-surface temperature to construct relations between hydrograph characteristics and the pattern of downstream flows. This information will form the basis for a protocol to develop estimates of potential recharge for given hydrographs within the MRGB.

The SSCM and environmental method are designed to estimate deep, long-term recharge rates on the decade-to-century recharge period. The thermalpulse tracking procedures are designed to monitor streambed infiltration distributions and short-term potential recharge on the daily-to-seasonal recharge period. A synthesis of this collaborative research will provide insight into short-term fluctuations in recharge and long-term average values for recharge along the eastern flank of the MRGB.

\section{REFERENCES}

Constantz, J. and Thomas, C.L., 1996, The use of streambed-temperature profiles to estimate the depth, duration, and rate of percolation beneath arroyos: Water Resources Research, v. 32, no. 12, p. 3597-3602.

Constantz, J. and Thomas, C.L., 1997, Streambed-temperature profiles as indicators of percolation characteristics beneath arroyos in the Middle Rio Grande Basin, USA: Hydrological Processes, v. 11, no. 12, p. 1621-1634.

Nimmo, J.R., Stonestrom, D.A., and Aksten, K.C., 1994, The feasibility of recharge rate measurements using the steady state centrifuge method: Soil Science Society of America Journal, v. 58, no. 1, p. 49-56.

Ronan, A.D., Prudic, D.E., and Constantz, J., 1997, Effects of diurnal stream temperature variation on infiltration beneath an ephemeral stream: American Geophysical Union Transactions, EOS, v. 78, no. 46, p. F304.

Stewart, A., Ronan, A.D., Constantz, J., and Freyberg, D., 1997, The influence of temperature and layering heterogeneity on transmission loss from an ephemeral stream: American Geophysical Union Transactions, EOS, v. 78, no. 46, p. F304. 


\title{
ENVIRONMENTAL TRACERS OF RECHARGE AT ABO ARROYO, BEAR CANYON, AND THE SANTA FE RIVER, MIDDLE RIO GRANDE BASIN, NEW MEXICO
}

\author{
David A. Stonestrom and Katherine C. Akstin \\ U.S. Geological Survey, Water Resources Division, \\ 345 Middlefield Road, MS 421, Menlo Park, CA 94025
}

To quantify spatial patterns of recharge in the Middle Rio Grande Basin (MRGB), environmental indicators were measured on transects along and between arroyos entering the east margin of the basin. This summary describes chloride and bromide results from interarroyo transects along the Santa $\mathrm{Fe}$ River near La Bajada (Santa Fe County), along Bear Canyon near Albuquerque (Bernalillo County), and along Abo Arroyo in a $28-\mathrm{km}$ reach extending approximately from Blue Springs to Veguita (Socorro County). The Santa Fe River and Abo Arroyo are two of the largest rivers entering the MRGB. Bear Canyon is one to two orders of magnitude smaller in drainage area and provides an example of the many small mountain-front drainages ringing the MRGB.

Continuous bulk samples of unsaturated soils and sediments were obtained with a pneumatic-driven core sampler driven to typical depths of 4 to $5 \mathrm{~m}$. In all, 29 vertical profiles were sampled, 17 in interarroyo areas and 12 in active channels. Two transects were sampled along the Santa Fe River, one $0.2 \mathrm{~km}$ upstream of exposed bedrock marking the mountain front, and one approximately $1 \mathrm{~km}$ downstream of the mountain front. One transect was sampled in Bear Canyon, approximately 0.3 km downstream of exposed bedrock marking the mountain front. Four transects were sampled along Abo Arroyo, $1.4 \mathrm{~km}$ upstream of the mountain front, and $0.4,4$, and $27 \mathrm{~km}$ downstream of the mountain front.

After drying samples to determine water content, soluble salts were extracted using methods described in Stone (1984). Chloride and bromide concentrations were determined using single-column ion chromatography with silica-bonded ion exchangers. Analytical uncertainty was about $\pm 5 \%$. Pore water concentrations of chloride ranged from 3 to $5100 \mathrm{mg} / \mathrm{L}$. Pore-water concentrations of bromide ranged from $<0.02$ to $62 \mathrm{mg} / \mathrm{L}$.

The solute-profile method of Allison was used to infer recharge rates from pore-water concentrations of chloride (Allison and others, 1994; Edmunds and others, 1988). A value of $0.29 \mathrm{mg} \mathrm{Cl} / \mathrm{L}$ precipitation was used to calculate chloride loading, based on wet and dry deposition collected in Santa Fe, New Mexico, from November 1987 to March 1989 (Anderholm, 1994). Local mean-annual precipitation values were interpolated from data in Thorn and others (1993).

Figure 14 shows profiles of water content and porewater concentrations of chloride and bromide for two holes of an example transect near Abo Arroyo. Bromide concentrations mimicked chloride concentrations in all profiles, with bromide-to-chloride ratios showing considerable variation among profiles. Bromide-to-chloride ratios were lowest in
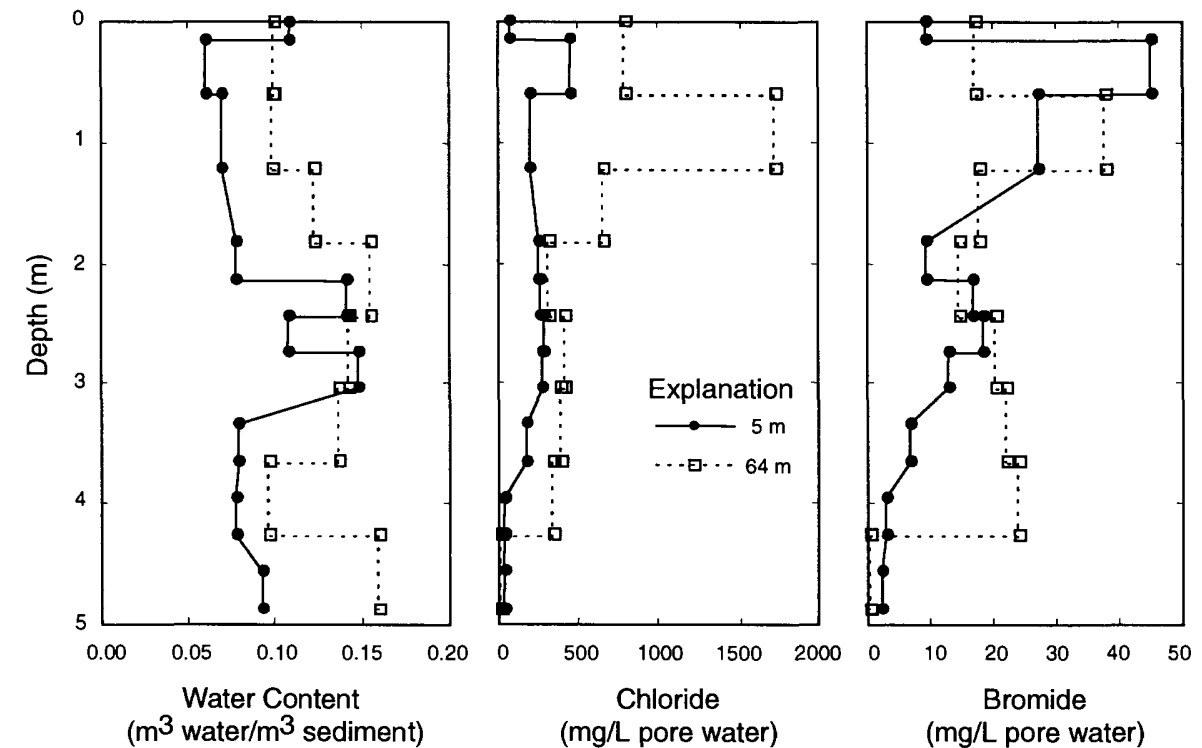

Figure 14. Profiles of water content and pore-water concentrations of chloride and bromide at distances of 5 and 64 meters from Abo Arroyo along a transect near the eastern margin of the Middle Rio Grande Basin, New Mexico. 
Santa Fe River pore waters, averaging 0.009, and highest in Bear Canyon pore waters, averaging 0.08. Ethylene bromide is a gasoline additive (Brehler and Fuge, 1978); Bear Canyon values thus probably reflect anthropogenic additions of bromide from metropolitan Albuquerque.

Interarroyo recharge rates based on chloride massbalance calculations evaluated at a depth of $4 \mathrm{~m}$ ranged from 0.04 to $5 \mathrm{~mm} / \mathrm{yr}$ (Fig. 15). A recharge rate of even $5 \mathrm{~mm} /$ year over the entire basin would provide only $4 \times 10^{7} \mathrm{~m}^{3}$ of cumulative recharge, or one-fifth the estimated amount of ground water withdrawn in 1990 (Thorn and others, 1993). The Bear Canyon transect had the highest recharge rates. The elevation of the Bear Canyon transect is about $1980 \mathrm{~m}$. Sandia Crest, immediately to the east, rises to an altitude above $3000 \mathrm{~m}$. Santa Fe and Abo transects range in elevation from 1450 to $1680 \mathrm{~m}$ and are located where the basin margin is significantly lower. The relatively high recharge rates at Bear Canyon are attributable mainly to orographic effects.

A consistent pattern of decreasing recharge rate with increasing distance from channel was observed in all transects (Fig. 15). It seems unlikely that chloride-loading rates varied over the short distances $(<0.5 \mathrm{~km})$ of individual transects, which were characterized by gross similarities in vegetation type, vegetation density, and elevation. The trend may be caused by a systematic variation in near-surface hydrologic balance due to changes in particle size distribution (hence, hydrologic parameters) with distance from the channels. Evaluation of this and other hypotheses is underway.
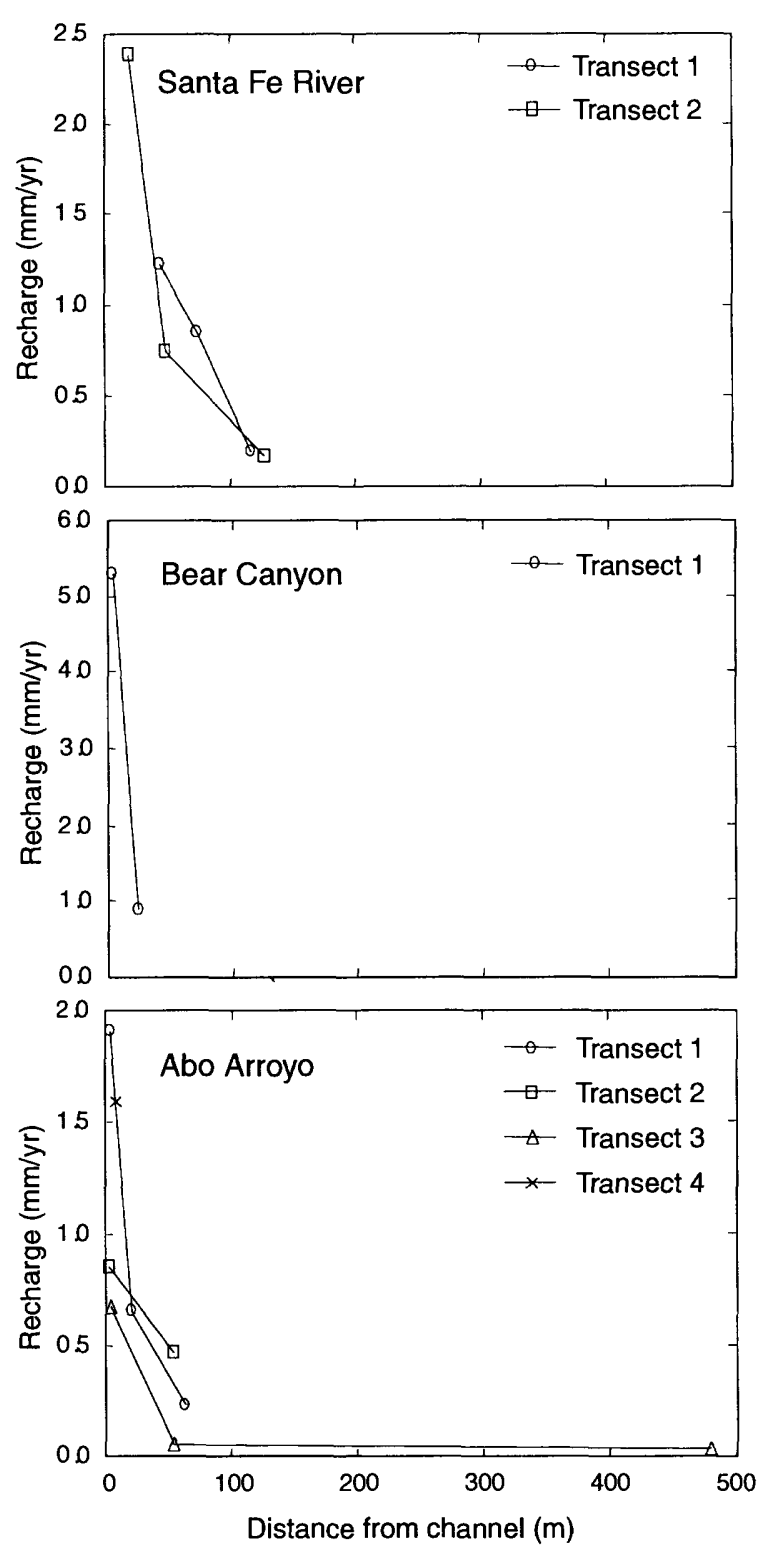

Figure 15. Interarroyo recharge rates inferred from solute profiles along the eastern margin of the Middle Rio Grande Basin, New Mexico.

\section{REFERENCES}

Allison, G.B., Gee, G.W., and Tyler, S.W., 1994, Vadose zone techniques for estimating groundwater recharge in arid and semiarid regions: Soil Science Society of America Journal, v. 58, p. 6-14.

Anderholm, S.K., 1994, Ground-water recharge near Santa Fe, north-central New Mexico: U.S. Geological Survey Water-Resources Investigations Report 94-4078, $68 \mathrm{p}$.

Brehler, B., and Fuge, R., 1978, Bromine, in Wedepohl, K.H., (ed.), Handbook of Geochemistry: New York, SpringerVerlag, p. 35-A-1 to 35-L-2.

Edmunds, W.M., Darling, W.G., and Kinniburgh, D.G., 1988, Solute profile techniques for recharge estimation in semiarid and arid terrain, in Summers, I., (ed.), Estimation of Natural Groundwater Recharge: Norwell, Mass., D. Reidel Publishing Co., p. 139-157.

Stone, W.J., 1984, Recharge in the Salt Lake Coal Field based on chloride in the unsaturated zone: New Mexico Bureau of Mines and Mineral Resources Open-File Report 214, 64 p. 
Thorn, C.R., McAda, D.P., and Kernodle, J.M., 1993, Geohydrologic framework and hydrologic conditions in the Albuquerque Basin, central New Mexico: U.S. Geological Survey Water-Resources Investigations Report 93-4149, 106 p.

\title{
THERMAL TRACKING TECHNIQUES TO ESTIMATE STREAMFLOW AND STREAMBED INFILTRATION ALONG THE EASTERN MIDDLE RIO GRANDE BASIN
}

\author{
Amy E. Stewart ${ }^{1,2}$, Anne D. Ronan ${ }^{3}$, and Jim Constantz ${ }^{1}$ \\ ${ }^{1}$ U.S. Geological Survey, Water Resources Division, Western Region, Branch of Regional Research, \\ 345 Middlefield Road, MS 496, Menlo Park, CA 94025 \\ ${ }^{2}$ Department of Civil \& Environmental Engineering, Stanford University, Stanford, CA 94305 \\ ${ }^{3}$ Department of Civil Engineering, San Jose State University, San Jose, CA 95192
}

Proper characterization of streamflow and streambed hydraulic properties is essential for determination of the spatial and temporal variations in arroyo streambed infiltration. Several techniques are being developed to use stream and streambed temperature patterns to thermally track the movement of water, both vertically and down canyon (Constantz and Thomas, 1996, 1997; Ronan and others, 1997; Stewart and others, 1997). Data obtained by these techniques may then be utilized as input in computer models or to validate model simulations. VS2DH, a two-dimensional, finite-difference model of heat and water transport in the unsaturated zone (Healy and Ronan 1996), is being used to simulate percolation properties below streambeds throughout the eastern portion of the Middle Rio Grande Basin (MRGB). Stream and streambed temperature data are used to calibrate this model. Field sites, representing a variety of locations in which recharge is believed to be important in arid environments, have been selected as representative of tributary and mountain-front recharge. These sites include the La Bajada reach along the Santa Fe River, a site at the mountain front of Bear Canyon, and a lower reach of Abo Arroyo. The Santa Fe River site represents a site of potential tributary recharge in the wetter, northern portion of the basin, while lower Abo Arroyo represents a site of potential tributary recharge in the dry, southern portion of the basin. A less extensive study is ongoing at Bear Canyon, representing a site of potential mountain-front recharge. In each of the sites water flows over the bedrock until reaching basin fill at the fault zones west of the mountains. As the streamflow travels over the more permeable alluvial material, cumulative infiltration increases until streamflow ceases and only groundwater flow continues toward the Rio Grande.

Although each field site is not instrumented in an identical manner, in general the thermal tracking protocol is as follows. At a given site, thermocouple wire "nests" were buried to approximately 3 meters (m). Each nest consists of five or six thermocouple wires attached to specific locations along a wooden guide. The assembly is inserted into a drill hole located in the low point of the stream channel. Temperature readings at multiple depths, usually along with stream and air temperatures, are recorded at 10-minute intervals on a Campbell CR10X or 21X data logger. (The mention of brand names does not constitute endorsement by the USGS.) Data loggers are situated along the stream banks either in preexisting USGS gage houses or in temporary secured shelters. Each field site has multiple thermocouple nests along the reach. Therefore, the water movement may be tracked as it vertically infiltrates, and to an extent, may be tracked as it flows down canyon through the subsurface.

VS2DH is being used to model infiltration on a transverse vertical cross-section at the Santa $\mathrm{Fe}$, $\mathrm{La}$ Bajada field site. A 2-D grid of the stream and bank system was developed to model variations in stream temperature and stage, both of which continuously fluctuate throughout the day. Simulated temperature values are then matched to subsurface temperature profiles from thermocouple data to estimate streambed infiltration rates for the crosssection. Due to operational problems related to stream diversions at the study site, only data from one thermocouple nest (TCN2) has been modeled 
using VS2DH. Initial results appear promising. For example, for a representative period during June 1997, percolation rates at TCN2 have been estimated to be on the order of $10^{-5} \mathrm{~m} / \mathrm{s}$. These values are within the range of streambed infiltration rates reported by Thomas and Constantz for a 1-kilometer $(\mathrm{km})$ subreach of the Santa Fe River that includes TCN2 (in these proceedings).

A second thermal-tracking technique is being developed to examine the spatial and temporal patterns in ephemeral reaches. The primary difficulty proved to be in developing instrumentation that will remain in place during flash-flooding events. We are using Onsett Temperature Probes to measure streambed-surface temperatures, at 1-hour intervals, at eight locations down Abo Arroyo. The probes are unevenly spaced down the $30-\mathrm{km}$ reach, with a majority of the probes concentrated near the fault zone. Each probe is encased in PVC pipe, with screened ends. The casings are tethered with aircraft cable to an anchoring steel rod, buried as deep as $2 \mathrm{~m}$ in the sediment. A record of temperature is collected, to analyze diurnal variations in streambed temperatures. Abrupt changes, followed by signifi- cant dampening of the diurnal temperature signal suggests the presence of streamflow at a given probe site. A USGS gage station is located at the top of the reach, on the bedrock. Streambed surfacetemperature probe and thermocouple-nest data collected from Abo Arroyo will be analyzed to relate streamflow hydrographs to spatial and temporal patterns in streamflow between the gaging station and the Rio Grande. This provides an indication of the potential recharge through time across the extent of the arroyo. A new computer program is being developed to couple a surface-water program with VS2DH so that the location of a simulated flood-wave toe may be compared to data collected from the streambed surface-temperature probes.

The Bear Canyon site consists of a study reach of only $300 \mathrm{~m}$, where two thermocouple nests are operating at the up-canyon and down-canyon boundaries of the study reach. Temperature data from the thermocouple nests will be used to detect the presence and duration of streamflows. During these periods of flow, data will be used with VS2DH to estimate streambed-percolation rates.

\section{References}

Constantz, J., and Thomas, C.L., 1996, The use of streambed-temperature profiles to estimate the depth, duration, and rate of percolation beneath arroyos: Water Resources Research, v. 32, no. 12, p. 3597-3602.

Constantz, J., and Thomas, C.L., 1997, Streambed-temperature profiles as indicators of percolation characteristics beneath arroyos in the Middle Rio Grande Basin, USA: Hydrological Processes, v. 11, no. 12, p. 1621-1634.

Healy, R.W., and Ronan, A.D., 1996, Documentation of computer program VS2DH for simulation of energy transport in variably saturated porous media--Modification of the U.S. Geological Survey's computer program VS2DT: U.S. Geological Survey Water-Resources Investigations Report 96-4230, 36 p.

Ronan, A.D., Prudic, D.E., and Constantz, J., 1997, Effects of diurnal stream temperature variation on infiltration beneath an ephemeral stream: EOS, Transactions, American Geophysical Union, v. 78, no. 46, p. F304.

Stewart, A., Ronan, A.D., Constantz, J., and Freyberg, D., 1997, The influence of temperature and layering heterogeneity on transmission loss from an ephemeral stream: American Geophysical Union Transactions, EOS, v. 78, no. 46, p. F304. 


\title{
PRELIMINARY GEOLOGIC, HYDROLOGIC, AND AEROMAGNETIC MAPS OF THE WESTERN THREE-QUARTERS OF THE PUEBLO OF ISLETA, CENTRAL NEW MEXICO
}

\author{
Florian Maldonado ${ }^{1}$, Dave W. Love ${ }^{2}$, Janet L. Slate ${ }^{1}$, V.J.S. Grauch ${ }^{3}$, Ward E. Sanford ${ }^{4}$, \\ Matthew Heizler ${ }^{2}$, William C. McIntosh ${ }^{2}$, and Nancy A. Shock ${ }^{1}$ \\ ${ }^{1}$ U.S. Geological Survey, National Cooperative Geologic Mapping, \\ Box 25046, MS 913, Denver, CO 80225 \\ ${ }^{2}$ New Mexico Bureau of Mines and Mineral Resources, \\ 801 Leroy Place, Socorro, NM 87801 \\ ${ }^{3}$ U.S. Geological Survey, Mineral Resources, \\ Box 25046, MS 964, Denver, CO 80225 \\ ${ }^{4}$ U.S. Geological Survey, Water Resources Division, \\ 12201 Sunrise Valley Drive, MS 430, Reston, VA 20192
}

Parts of 12 quadrangles, encompassing the Pueblo of Isleta, central New Mexico, are being mapped at 1:24,000 scale and compiled at 1:50,000 scale, as part of the Middle Rio Grande Basin Study. Mapping by the U.S. Geological Survey and New Mexico Bureau of Mines and Mineral Resources depicts the geology, hydrology, and aeromagnetometry of the area. Our geologic map shows the western three-quarters of the pueblo from the Rio Puerco on the west to the base of the Manzano Mountains on the east. The major geomorphic features of the mapped quadrangles include the Rio Grande and Rio Puerco valleys; Llano de Alburquerque and Llano de Manzano; Wind Mesa, Cat Mesa, Cat Hills, and Isleta volcano and associated flows; Hell Canyon; ManzanoManzanita piedmont slopes; Hubbell Bench; and McCormick Ranch closed basin and playa. Major geologic features within the area are: (1) five basaltic volcanic fields; (2) deposits of the Santa Fe Group; (3) piedmont deposits from the Manzano and Manzanita Mountains; (4) post-Santa Fe Group terrace deposits; (5) calcic soils; (6) fluvial deposits of the present Rio Puerco and Rio Grande; (7) eolian dunes; and (8) high-angle normal faults.

The basaltic fields in the western half of the area, from youngest to the oldest, are: Cat Hills, Black Mesa, Isleta, Cat Mesa, and Wind Mesa. The Cat Hills field is composed of seven lava flows and 21 cinder cones. Samples from the oldest flow have ${ }^{40} \mathrm{Ar} /{ }^{39} \mathrm{Ar}$ whole-rock ages of $0.11 \pm 0.03$ and $0.098 \pm$ $0.02 \mathrm{Ma}$. An earlier K-Ar age for the oldest flow is $0.14 \pm 0.04 \mathrm{Ma}$ (Kudo and others, 1977). Samples from the youngest flow have discordant ${ }^{40} \mathrm{Ar} /{ }^{39} \mathrm{Ar}$ whole-rock ages of $0.49 \pm 0.16 \mathrm{Ma}$ and $0.25 \pm 0.08$ Ma. A dike exposed in the northernmost cinder cone has a ${ }^{40} \mathrm{Ar} /{ }^{39} \mathrm{Ar}$ whole-rock age of $0.18 \pm 0.08$ $\mathrm{Ma}$. This and other cinder cones are aligned on a north-northeast striking fissure zone.

The Black Mesa basaltic lava flow is exposed eastnortheast of the Isleta field and is interbedded with Rio Puerco sand and gravel facies of the upper part of the Santa Fe Group. No volcanic source for this flow has been identified. A sample from this field has a ${ }^{40} \mathrm{Ar} /{ }^{39} \mathrm{Ar}$ age of $2.68 \pm 0.04 \mathrm{Ma}$.

The Isleta field is composed of five lava flows, two cinder cones, and one tuff ring (Kelley and Kudo, 1978). The lowest flow has a ${ }^{40} \mathrm{Ar} /{ }^{39} \mathrm{Ar}$ age of $2.75 \pm$ $0.12 \mathrm{Ma}$ and the overlying flow a ${ }^{40} \mathrm{Ar} /{ }^{39} \mathrm{Ar}$ age of $2.72 \pm 0.08 \mathrm{Ma}$ and an earlier K-Ar age of $2.78 \pm 0.12$ Ma (Kudo and others, 1977).

The Cat Mesa field consists of a thick lava flow found locally at the base of the clay and silt facies of the Santa Fe Group and below the calcic soils of the Llano de Alburquerque. A sample from this field has a ${ }^{40} \mathrm{Ar} /{ }^{39} \mathrm{Ar}$ whole rock age of $3.00 \pm 0.10 \mathrm{Ma}$.

The Wind Mesa field consists of three lava flows with minor cinder deposits. The flows are faulted and appear to be part of an exhumed volcano. Ancestral Rio Puerco pebbles on the lava flow above the present Santa Fe-lava flow contact support this interpretation. A sample of the oldest flow has a ${ }^{40} \mathrm{Ar} /{ }^{39} \mathrm{Ar}$ whole-rock age of $4.01 \pm 0.16 \mathrm{Ma}$. 
The exposed Santa Fe Group is considered part of the Sierra Ladrones Formation of Machette (1978), and consists of piedmont conglomerates and sandy siltstones, and fluvial deposits of an ancestral Rio Puerco and ancestral Rio Grande. We have divided the ancestral Rio Puerco deposits in the westernmost part of the map area into three lithofacies that are based on grain size and clast content. From youngest to oldest, the facies are: (1) sand and gravel; (2) silt, sand, and clay; and (3) coarse sand and gravel. The basalt of Cat Mesa, dated at about 3 $\mathrm{Ma}$, is at the base of the silt, sand, and clay facies. Along both sides of the Rio Grande valley, ancestral Rio Puerco facies are primarily sand with pebbles and cobbles. The ancestral Rio Grande deposits are exposed east of the Rio Grande valley and are mapped as a lower fine-grained facies and an upper coarse-grained facies. The upper facies consists of coarse sand, pebbles, and cobbles, with rare boulders of the Tshirege Member of the Bandelier Tuff, as much as $4 \mathrm{~m}$ long. The Tshirege ash (1.22 Ma) is occasionally preserved close to the contact between the two facies.

Piedmont alluvial aprons from the ManzanoManzanita Mountains have soils that range from Pliocene to Holocene age. A sequence of as many as five Quaternary terraces is preserved along Hell Canyon, which is entrenched below the oldest piedmont alluvial apron. As many as 20 Quaternary terraces occur along the smaller tributaries.

Post Santa Fe terrace deposits are found along the present Rio Grande inset against the Sierra Ladrones Formation. The most extensive terrace deposit makes up the Los Duranes Formation. The Los Duranes Formation is older than the Cat Hills flow that overlies it-dated at $0.14,0.11$, and 0.098 Ma.

West of the Rio Grande, widespread calcic soils are mapped separately as calcic soils, and calcic soils of the Llano de Alburquerque. The calcic soils are younger than the soils of the Llano and are found interbedded with and below eolian deposits. The morphological stage of soil development (Machette, 1985) ranges from poorly developed stage I to stage III. Stage III soils are commonly found on the flanks of the Cat Hills cinder cones. The calcic soils of the Llano de Alburquerque range from stage III to IV, overlie the sand and gravel facies of the Rio Puerco, and are overlain by the basaltic flow of the Cat Hills. Therefore, the Llano surface is older than the discordant range of ages (0.098 $\mathrm{Ma}$ to $0.49 \mathrm{Ma}$ ) of the Cat Hills basalt flows and considerably younger than the basalt of Cat Mesa ( $3 \mathrm{Ma}$ ).

East of the Rio Grande, a thick stage III to IV calcic soil, referred to as the calcic soils at the top of the ancestral Rio Grande, overlies the ancestral Rio Grande sandy-gravel deposits. These deposits contain pumice and reworked ash and large clasts of the 1.22-Ma Tshirege Member of the Bandelier Tuff. Locally, less developed calcic horizons in eolian sand overlie the thicker soil.

Holocene fluvial deposits are mapped in the westernmost part of the map area along the Rio Puerco and along the Rio Grande. The Rio Puerco deposits are divided into three terraces and the present Rio Puerco channel. The present river channel was delineated from aerial photography dated 1990 and has deviated as much as $1 / 4 \mathrm{~km}$ from the former channel, shown on the 1952 topographic 1:24,000scale base. The Rio Grande valley deposits are divided into the modern floodway of pebbly sand and fine-sand-to-clay floodplain.

Widespread eolian deposits are composed of sheets and dunes of Holocene to Pleistocene age. These include: (1) longitudinal dunes indicating winds dominantly from the west-southwest; (2) dunes deposited along the escarpment edge, above the Rio Puerco in the westernmost part of the map area and above bluffs along the eastern margin of the Rio Grande valley; (3) dunes deposited against topographic highs, including fault scarps; and (4) dunes and sheets descending into the Rio Grande valley from the Llano de Alburquerque.

A northerly striking, high-angle normal-fault zone forms a complex of grabens, half grabens, and horsts in the map area. From west to east, seven major fault zones include the: Garcia (new name), Cat Mesa, Cedar Wash (new name), Palace-Pipeline (new name), McCormick Ranch, Hubbell Spring, and Sanchez faults. The Garcia fault, on the western edge of the map area, is part of a fault zone that represents the western edge of the Rio Grande Rift. The Cat Mesa fault offsets the basalts of Cat Mesa and Cat Hills, the calcic soils of Llano de Alburquerque, and the Santa Fe Group. The Cedar Wash, an east-northeast-trending fault zone, was identified southwest of the Isleta volcanic field. Another eastnorthwest-trending fault is inferred beneath part of Hell Canyon. The Palace-Pipeline fault zone, consisting of three or more north-trending faults, displaces Santa Fe deposits along a pipeline south of 
Hell Canyon and can be traced northward. The McCormick Ranch fault is a down-to-the-east fault east of a horst trending north from Hell Canyon. The Hubbell Spring fault zone consists of two or more north-northeast-trending faults. East of the easternmost strand, lower Mesozoic and upper Paleozoic rocks deformed by Laramide compression are exposed beneath $15 \mathrm{~m}$ to $30 \mathrm{~m}$ of old cemented piedmont gravel and overlying finer-grained sediments.

The signatures on the aeromagnetic map correspond to the major faults and volcanic fields that have been mapped at the surface. Both the hydrologically important Cat-Mesa and HubbellSpring faults are expressed on the aeromagnetic map. In addition, the map suggests that some segments considered part of the Hubbell Spring fault may not be connected.
The ground-water-level contour map shows steep gradients in the western and eastern parts of the map separated by a trough (Titus, 1963). The western (Cat Mesa) gradient, on the west side of the Cat Mesa fault, may reflect the juxtaposition of fractured basaltic rocks and coarser-grained Santa $\mathrm{Fe}$ Group (hanging wall, east side of fault) against finer-grained facies of the Santa Fe Group (foot wall, west side of fault). Another possibility is a northerly-striking fissure system that acts as a steep ground-water barrier parallel to the Cat Mesa fault. The alignment of the Cat Hills cinder cones and distribution of lava flows may reflect a fissure. A wide ground-water trough, which appears to plunge to the south, separates the Cat Mesa gradient from the steep eastern gradient. The eastern gradient, located along the Hubbell Spring fault, likely represents juxtaposition of basin-fill material with bedrock.

\section{REFERENCES}

Kelley, V.C. and Kudo, A.M., 1978, Volcanoes and related basalts of the Albuquerque Basin, New Mexico: New Mexico Bureau of Mines and Mineral Resources, Circular 156, $30 \mathrm{p}$.

Kudo, A. M., Kelley, V.C., Damon, P.E., and Shafiquallah, M., 1977, K-Ar ages of basalt flows at Canjilon Hill, Isleta volcano, and Cat Hills volcanic field, Alburquerque-Belen Basin, central New Mexico: Isochron/West, no. 18, p. 15-16.

Machette, M.N., 1978, Geologic map of the San Acacia quadrangle, Socorro County, New Mexico: U.S. Geological Survey Geologic Quadrangle Map GQ-1415, scale 1:24,000.

Machette, M.N., 1985, Calcic soils of the southwestern United States, in Weide, D.L., (ed.), Soils and Quaternary geology of the southwestern United States: Geological Society of America Special Paper 203, p. 1-21.

Titus, F.B., Jr., 1963, Geology and ground-water conditions in eastern Valencia County, New Mexico: State Bureau of Mines and Mineral Resources, New Mexico Institute of Mines and Technology, Ground-Water Report 7, 113 p. 


\title{
PRELIMINARY PALEOSEISMIC ANALYSIS OF A TRENCH ACROSS THE HUBBELL SPRING FAULT NEAR ALBUQUERQUE, NEW MEXICO
}

\author{
Stephen F. Personius \\ U.S. Geological Survey, Geologic Hazards Team, \\ Box 25046, MS 966, Denver, CO 80225
}

The Hubbell Spring fault (HSF) is a down-to-thewest, north-trending normal fault that lies $5-11 \mathrm{~km}$ east of the basin-bounding Manzano fault zone in the east-central part of the Albuquerque basin. The HSF forms the western margin of a prominent intrabasin topographic and structural high known as the Hubbell bench; conspicuous fault scarps mark its length. At its northern end, the HSF merges with the Tijeras-Cañoncito fault system at the Travertine Hills in Sandia National Laboratories. The HSF extends south from the Travertine Hills about $34 \mathrm{~km}$ to the latitude of Belen. Previous mapping and scarp-morphology studies (Machette and McGimsey, 1983) indicate that the HSF is one of the more recently active faults in the Albuquerque area, and probably represents the active margin of the modern Rio Grande rift in this part of the basin. The present study was initiated because no previous paleoseismic studies had been conducted on the HSF, despite its proximity to Sandia National Laboratories and the Albuquerque metropolitan area. The goals of this study are to determine the timing, recurrence, and estimated magnitude of the last several paleoearthquakes on the HSF.

In September 1997, a 60-m-long exploratory trench was excavated across the HSF on Isleta Pueblo tribal lands $1.2 \mathrm{~km}$ south of the southern boundary of Sandia National Laboratories. The trench crossed a 7-m-high scarp formed on middle Pleistocene alluvial-fan deposits derived from the Hubbell bench and Manzano Mountains to the east (Love and others, 1996). The trench exposed two primary fault zones (herein referred to as the eastern and western strands) and an intervening 16-m-wide horse block that is broken by numerous small displacement synthetic and antithetic faults. In the upthrown block of the eastern strand, well sorted fluvial sands of the lower Pleistocene, upper Santa Fe Group are unconformably overlain by fan alluvium consisting of sandy coarse pebble and cobble gravel; a prominent stage III-IV calcic soil is formed in the upper part of the fan deposits. Three wedges of sandy eolian/colluvial sediment are preserved in the deformation zone. A thin layer of mixed eolian sand and pebbly slope-wash colluvium lies unfaulted across the fault scarp at the surface of the trench.

Comparisons between sandy eolian/colluvial wedges and fault-scarp colluvial wedges described elsewhere in the western U.S. (summarized in McCalpin, 1996) suggest that each of the sandy wedges exposed in the trench formed in response to a surface-rupturing earthquake. The oldest wedge lies unconformably on fan deposits, appears to thicken to as much as $150 \mathrm{~cm}$ in the downthrown blocks of both the eastern and western fault strands, and is preserved across most of the fault scarp. Its presence in the upthrown block $15 \mathrm{~m}$ east of the eastern strand as well as in the downthrown block of the western strand suggests that it was deposited after formation of fault scarps on both the eastern and western fault strands. This wedge has subsequently been faulted about $30 \mathrm{~cm}$ across the eastern strand and at least $60 \mathrm{~cm}$ across the western strand. The intermediate wedge is primarily preserved from the eastern strand westward, suggesting that it formed after a second surface-rupturing earthquake on the western strand. Additional evidence for a second event includes the presence of several upward-truncated fractures and a buried stage II-III calcic soil at the boundary between the oldest and intermediate wedges. The intermediate wedge has a maximum thickness of about $130 \mathrm{~cm}$ in the hanging wall of the western strand, although extensive rodent burrowing adjacent to the western strand prevents measurement of its maximum thickness. This wedge has subsequently been faulted about 30 $\mathrm{cm}$ across the eastern strand and about $40 \mathrm{~cm}$ across the western strand. The youngest wedge thickens to about $100 \mathrm{~cm}$ just west of the western fault strand, and is preserved only in the hanging wall and about $5 \mathrm{~m}$ of the horse block. This wedge is unfaulted and lies on an eroded scarp free-face cut into the intermediate wedge in the horse block.

The composition and geometry of the eolian/colluvial wedges indicate that they were probably formed by a combination of eolian sand deposition by prevailing westerly winds and collu- 
viation from eroded fault scarps formed during three surface-rupturing earthquakes. Climatically driven episodes of eolian sand deposition may be reflected as thin buried soils within the wedges, but the thickness of these sedimentary packages indicates that infrequent surface-faulting events probably created the space needed for wedge deposition and preservation. Because eolian processes can rapidly bury landforms in this environment, wedge thickness is probably a reasonable approximation of vertical offset associated with individual surfacerupturing earthquakes. The thickness of preserved wedges $(1-1.5 \mathrm{~m})$ indicates a likely range in offset of 1-2 $\mathrm{m}$ at the trench site. This range is reasonable, given that the number of probable events (3) and net vertical offset in the underlying alluvial fan deposits $(4.7 \mathrm{~m})$ indicate an average net vertical offset of about $1.6 \mathrm{~m}$ per surface faulting event. Compari- sons between rupture parameters associated with large historic normal-fault earthquakes elsewhere (Wells and Coppersmith, 1994), a mapped fault length of $34 \mathrm{~km}$, and offsets of 1-2 m yield estimated earthquake magnitudes of $M_{w}$ 6.9-7.1 for the last three surface-rupturing earthquakes on the HSF.

The timing of surface-rupturing earthquakes on the HSF is presently unknown, but soil data and pending TL ages on wedge deposits should allow determination of two recurrence intervals and the elapsed time since the most recent event. Preliminary soil data suggest that the most recent event occurred at least several tens of thousands of years before present, and that recurrence intervals between events may be of similar or longer duration.

\section{REFERENCES}

Love, D.W., Hitchcock, C., Thomas, E., Kelson, K., Van Hart, D., Cather, S., Chamberlin, R., Anderson, O., Hawley, J., Gillentine, J., White, W., Noller, J., Sawyer, T., Nyman, M., and Harrison, B., 1996, Geology of the Hubbell Spring 7.5-min quadrangle, Bernalillo and Valencia Counties, New Mexico: New Mexico Bureau of Mines and Mineral Resources Open-File Digital Map OF-DM 5, 7 p. pamphlet, 1 sheet, scale 1:24,000.

Machette, M.N., and McGimsey, R.G., 1983, Quaternary and Pliocene faults in the Socorro and western part of the Fort Sumner $1^{\circ} \times 2^{\circ}$ quadrangles, New Mexico: U.S. Geological Survey Miscellaneous Field Studies Map MF-1465, scale $1: 250,000$.

McCalpin, J.P., 1996, Paleoseismology: San Diego, Academic Press, 588 p.

Wells, Donald, and Coppersmith, K.J., 1994, New empirical relationships among magnitude, rupture length, rupture width, rupture area, and surface displacement: Bulletin of the Seismological Society of America, v. 84, p. 974-1002. 


\title{
MOUNTAIN-FRONT RECHARGE ALONG THE EASTERN SIDE OF THE MIDDLE RIO GRANDE BASIN, CENTRAL NEW MEXICO
}

\author{
Scott K. Anderholm \\ U.S. Geological Survey, Water Resources Division, \\ 4501 Indian School Road, N.E., Suite 200, Albuquerque, NM 87110
}

Mountain-front recharge along the eastern side of the Middle Rio Grande Basin is an important component of recharge to the basin-fill aquifer. Mountain-front recharge occurs along the interface between the basin-fill deposits and the bedrock of the surrounding mountains (mountain front). Little is known about the volume of mountain-front recharge to the basin-fill aquifer because there have been few studies. This article discusses mountainfront recharge, factors that affect mountain-front recharge, and methods that have been used to estimate mountain-front recharge, and presents estimates of mountain-front recharge for one area along the eastern side of the basin.

Mountain-front recharge to the basin-fill aquifer can be divided into two components: (1) subsurface flow of ground water from the mountainous areas to the basin-fill aquifer; and (2) infiltration of streamflow from streams or channels that drain the mountainous areas. Several factors influence the quantity of each component. The volume of precipitation in the mountainous areas is a major factor influencing mountain-front recharge. The volume of winter precipitation relative to summer precipitation partially determines the volume of water available for recharge because the evapotranspiration rates are much larger in the summer than in the winter. The permeability of the bedrock in the mountainous areas and the basin-fill deposits can also affect the volume of mountain-front recharge and the relative importance of the two different components of mountain-front recharge. The volume of subsurface flow of ground water from the mountainous areas to the basin-fill aquifer is difficult to estimate or measure directly. Streamflow at the mountain front can be measured, thereby allowing estimation of the volume of mountain-front recharge resulting from infiltration of streamflow.

Methods for estimating mountain-front recharge or one of its components can be grouped into water balances, ground-water-flow models, rainfall/runoff relations, or chemical balances. Waterbalance methods generally use estimates of pre- cipitation, evapotranspiration, sublimation, and runoff to calculate mountain-front recharge as a residual. Ground-water-flow models are used to calculate water levels and water balances. The volume of mountain-front recharge can be adjusted until the model simulates the known water levels and other measured components of the water balance. Rainfall/runoff methods have been used to estimate streamflow at the mountain front from ungaged mountainous watersheds. Regression equations generally are developed using streamflow data from gaged watersheds that have characteristics similar to those of watersheds where the equations will be applied. Precipitation (mean annual or mean-annual winter precipitation) and watershed or basin area are the most common variables used in the regression equations. The estimates of streamflow made using the regression equations are used to estimate the infiltration of streamflow component of mountain-front recharge. Chemicalbalance methods use estimates of mean annual precipitation and the concentration of a relatively conservative solute in precipitation and ground water near the mountain front to estimate mountain-front recharge.

Two rainfall/runoff methods and a chemicalbalance method were applied to an area of the Manzano Mountains along the eastern side of the Middle Rio Grande Basin (Fig. 16). The bedrock in this area of 60.8 square miles $\left(157.5 \mathrm{~km}^{2}\right)$ consists of relatively impermeable Precambrian igneous and metamorphic rocks. The volume of mean annual precipitation is about 65,200 acre-feet and the volume of mean-annual winter precipitation is about 28,600 acre-feet. Mean annual precipitation is about 20.1 in $(51 \mathrm{~cm})$, and mean-annual winter precipitation is about 8.8 in $(22 \mathrm{~cm})$.

Rainfall/runoff equations that were developed to estimate runoff from mountainous areas in southern Colorado (eq. 1) and southern New Mexico (eq. 2) were used to estimate streamflow at the mountain front of the Manzano Mountains area. 


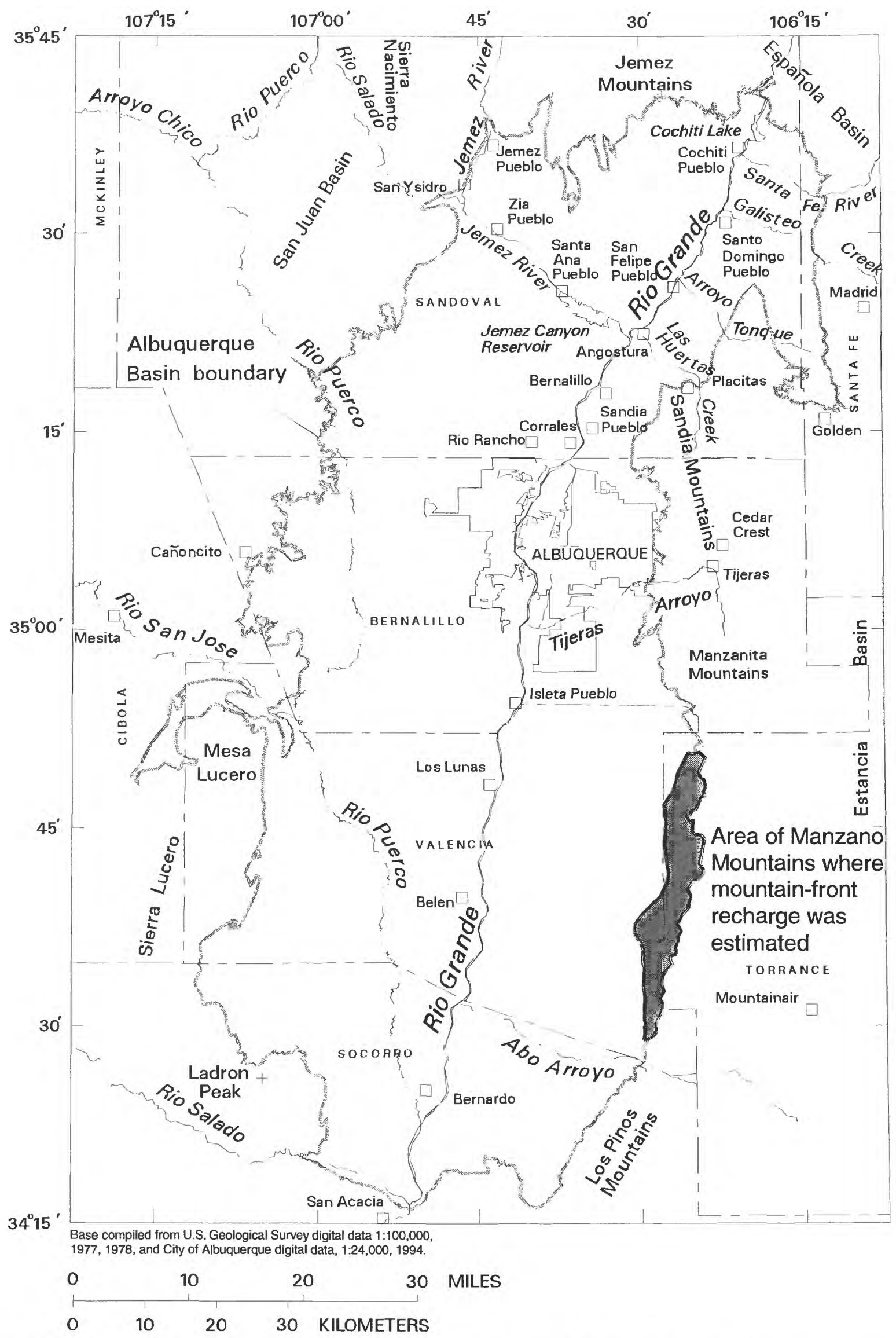

Figure 16. Albuquerque Basin and area where mountain-front recharge was estimated (modified from McAda, 1996). 


$$
\begin{aligned}
& \mathrm{Q}=0.0552 \mathrm{~A}^{0.977} \mathrm{Pw}^{3.596} \\
& \text { (Hearne and Dewey, 1988, p. 31) } \\
& \qquad=0.123 \mathrm{~A}^{1.65} \mathrm{P} 1.35 \\
& \text { (Waltemeyer, 1994, p. 3) }
\end{aligned}
$$

where $Q$ is mean annual streamflow, in acre-feet; $A$ is area, in square miles; $\mathrm{Pw}$ is mean-annual winter precipitation, in inches; and $\mathrm{P}$ is mean annual precipitation, in inches.

The streamflow at the mountain front, or the water available for mountain-front recharge as the result of infiltration of streamflow from the mountainous area, was about 7,600 acre-feet using equation 1 and about 6,200 acre-feet using equation 2 . These estimates represent the maximum volume of surface water that could infiltrate and recharge the basin-fill aquifer because part of this water could evaporate or be transpired prior to or during infiltration. These values underestimate mountain-front recharge because they do not include subsurface flow of ground water from the mountainous area to the basin-fill deposits. The bedrock in the Manzano Mountains area is relatively impermeable, however, and subsurface inflow of ground water probably is small.

A chloride-balance method results in an estimate of mountain-front recharge for the Manzano Mountains area of about 3,900 acre-feet using the following equation (Anderholm, 1994):

$$
\mathrm{R}=\mathrm{Pt} \mathrm{Cp} / \mathrm{Cgw}
$$

where $\mathrm{R}$ is mean-annual mountain-front recharge, in acre-feet; $\mathrm{Pt}$ is mean annual precipitation, in acrefeet; $\mathrm{Cp}$ is the chloride concentration in precipitation (0.3 milligram per liter); and Cgw is the chloride concentration in ground water near the mountain front (5.0 milligrams per liter).

Although the methods use different approaches and assumptions, the estimates of mountain-front recharge calculated using the rainfall/runoff methods (7,600 and 6,200 acre-feet per year) and the chloridebalance method (3,900 acre-feet per year) are similar. Based on these estimates, 6 to 12 percent of the mean annual precipitation in the Manzano Mountains area results in mountain-front recharge to the basin-fill aquifer.

\section{REFERENCES}

Anderholm, S.K., 1994, Ground-water recharge near Santa Fe, north-central New Mexico: U.S. Geological Survey Water-Resources Investigations Report 94-4078, $68 \mathrm{p}$.

Hearne, G.A., and Dewey, J.D., 1988, Hydrologic analysis of the Rio Grande basin north of Embudo, New Mexico, Colorado and New Mexico: U.S. Geological Survey Water-Resources Investigations Report 86-4113, 244 p.

McAda, D.P., 1996, Plan of study to quantify the hydrologic relations between the Rio Grande and the Santa Fe Group Aquifer System near Albuquerque, central New Mexico: U.S. Geological Survey Water-Resources Investigations Report 96-4006, $58 \mathrm{p}$.

Waltemeyer, S.D., 1994, Methods for estimating streamflow at mountain fronts in southern New Mexico: U.S. Geological Survey Water-Resources Investigations Report 93-4213, 17 p. 


\title{
PRELIMINARY RESULTS OF AQUIFER-RECHARGE ESTIMATES INTERPRETED FROM CENTRIFUGE HYDRAULIC PROPERTY MEASUREMENTS, ABO ARROYO, MIDDLE RIO GRANDE BASIN, NEW MEXICO
}

\author{
Angus M. Lewis and John R. Nimmo \\ U.S. Geological Survey, Water Resources Division, Branch of Regional Research, \\ 345 Middlefield Road, MS 421, Menlo Park, CA 94025
}

\begin{abstract}
Abo Arroyo is an important source of tributary recharge in the Middle Rio Grande Basin (MRGB); therefore, recharge-rate measurements in and near the arroyo are valuable. We have measured unsaturated hydraulic conductivity $(\mathrm{K})$ for ten core samples from Abo Arroyo and adjacent terraces using the steady-state centrifuge method (SSCM), and have interpreted point-recharge estimates from these results. These samples came from four locations along a $30-\mathrm{km}$ reach, from depths of 0.4 to 5.4 m.
\end{abstract}

Accurate measurement of unsaturated hydraulic conductivity $(\mathrm{K})$ and soil moisture can indicate long-term average-recharge rates at selected geographic points (Nimmo and others, 1994). This method requires core samples from deep enough such that moisture fluctuations are negligible, implying that water flow is steady. If the matric pressure gradient is known, or if it can be assumed to be negligible, the value of $K$ at the field-water content can indicate downward flux density $(\mathrm{q})$. This can be interpreted as the long-term average-recharge rate at the position of the sample. The steady-state centrifuge method (SSCM) is well suited for the required measurements because it gives $K$ values in the low-water-content range important at arid and semi-arid sites. We used the steady-state centrifuge method in conjunction with the unsaturated flow apparatus (UFA) (Conca and Wright, 1992) to measure unsaturated hydraulic conductivity of the core samples. The samples were taken in the field using a Geoprobe (Stonestrom and Akstin, 1998), and the UFA was modified for use with these core samples. (Mention of brand names does not constitute endorsement by the U.S. Geological Survey.) Each sample was run through a series of steadystate measurements covering a range of unsaturated hydraulic conductivity values such that the corresponding water contents bracketed the field-water content of the samples. This permitted an estimate of $\mathrm{K}$ at the field-water contents. Assuming gravity alone drives flow, these $\mathrm{K}$ values directly indicate $\mathrm{q}$.
Preliminary results give $q$ estimates that range from 1 to $2700 \mathrm{~cm} / \mathrm{yr}$ for core samples taken within the active channel. For samples taken 5 to $500 \mathrm{~m}$ away on the adjacent terraces, $q$ estimates are less than $5 \times 10^{-5} \mathrm{~cm} / \mathrm{yr}$, suggesting that recharge rates drop off sharply outside the arroyo. Comparing different depths, two core samples taken from a single borehole within the active channel, 0.4 and $0.5 \mathrm{~m}$ below the surface, show very different recharge rates $(60$ and $470 \mathrm{~cm} / \mathrm{yr}$ ). These values are significantly less than estimated $q$ values for two core samples taken from the same borehole at depths of 1.9 and $2.0 \mathrm{~m}$ (2300 and $2700 \mathrm{~cm} / \mathrm{yr}$ ). This variation with depth suggests that the two shallower samples are not deep enough to assume steady flow. The approximate equality of recharge rates from the two samples taken at 1.9 and $2.0 \mathrm{~m}$, however, is consistent with the assumptions of our method. Aside from the uncertainty in steadiness of flow, there is possible additional error if matric potential gradients are large enough to invalidate the assumption of flow driven by gravity alone. To evaluate these uncertainties and the possibility of lateral flow, SSCM measurements will be interpreted by a mathematical simulation of Darcian flow (Nimmo and others, 1996, 1997). Lateral flow is also important for the evaluation of the total quantity of recharge from Abo Arroyo.

Results show that recharge rates vary along the reach within the active channel. Four samples, taken at three different locations within the active channel, give results consistent with the assumptions of our method. Three of these samples have $\mathrm{q}$ estimates that fall in a relatively narrow range of 1900 to $2700 \mathrm{~cm} / \mathrm{yr}$; the $\mathrm{q}$ estimate of the fourth is only $1 \mathrm{~cm} / \mathrm{yr}$. Of the three locations along the arroyo, the highest recharge estimates (2300 and 2700 $\mathrm{cm} / \mathrm{yr}$ ) come from the upper reaches (canyon) of Abo Arroyo. The lowest recharge rate $(1 \mathrm{~cm} / \mathrm{yr})$ occurs $2.5 \mathrm{~km}$ downstream, where Abo Arroyo enters the basin plain. The recharge rate appears to increase again $(1900 \mathrm{~cm} / \mathrm{yr}) 27 \mathrm{~km}$ downstream. Further SSCM core-sample measurements where 
Abo Arroyo enters the basin plain will test the validity of the lowest recharge rate.

Results thus far indicate the steady-state centrifuge method (SSCM) is useful for estimating pointrecharge rates, provided the core samples are deep enough such that flow is steady and driven by gravity alone. Further core-sample measurements will provide more point-recharge estimates, and a mathematical simulation of Darcian flow will allow us to evaluate the assumptions of steady flow and uniform matric potential, and to evaluate the possibility of lateral flow. Current results suggest that recharge in the arroyo itself is substantial, while recharge on the adjacent terraces appears to be negligible.

\section{REFERENCES}

Conca, J.L., and Wright, J., 1992, Diffusion and flow in gravel, soil, and whole rock: Applied Hydrogeology, v. 1, p. 524.

Nimmo, J.R., Stonestrom, D.A., and Akstin, K.C., 1994, The feasibility of recharge rate measurements using the steady state centrifuge method: Soil Science Society of America Journal, v. 58, p. 49-56.

Nimmo, J.R., Deason, J.A., Liaw, S.J., Izbicki, J.A., and Martin, P., 1996, Measurement and interpretation of recharging fluxes through layered alluvium under a Mojave Desert wash [abs.]: Fall meeting, American Geophysical Union, San Francisco, EOS, v. 77, no. 46, p. F283.

Nimmo, J.R., Deason, J.A., Izbicki, J.A., and Martin, P., 1997, Measurements and theory to determine recharge and horizontal spreading under a Mojave Desert wash [abs.]: Annual meeting, Soil Science Society of America, Anaheim, CA, 1997, Agronomy Abstracts, p. 170.

Stonestrom, D.A., and Akstin, K.A., 1998, Environmental tracers of recharge at Abo Arroyo, Bear Canyon, and the Santa Fe River, Middle Rio Grande Basin, New Mexico, in Slate, J.L., (ed.), Middle Rio Grande Basin Study-Proceedings of the second annual workshop, Albuquerque, New Mexico, February 10-11, 1998: U.S. Geological Survey Open-File Report 98-337. 


\title{
THE MIDDLE RIO GRANDE BASIN DIGITAL CARTOGRAPHY PROGRAM OF THE NEW MEXICO BUREAU OF MINES AND MINERAL RESOURCES
}

\author{
David J. McCraw, Paul W. Bauer, and Glen E. Jones \\ New Mexico Bureau of Mines and Mineral Resources, \\ 801 Leroy Place, Socorro, NM 87801 \\ $<$ djmc@nmt.edu $>$
}

Modern, accurate geohydrologic map information provides essential base data for government planning and scientific study. The New Mexico Bureau of Mines and Mineral Resources (NMBMMR), an active participant in the ongoing Middle Rio Grande Basin Study, has developed a new series of openfile, digital geologic-quadrangle maps (OF-DM). (See current availability of OF-DM series below.) These maps, funded by matching-funds grants of the National Geologic Mapping Act STATEMAP program, coordinated by the U.S. Geological Survey (USGS) and NMBMMR, provide the public with prompt, new geologic data at scales of either $1: 24,000$ or $1: 12,000$. We produce a variety of formats: (1) high-quality multicolor inkjet plots complete with cross sections, unit descriptions, and correlation charts; (2) a collection of $\mathrm{ARC} / \mathrm{INFO}^{\circledR}$ coverages for GIS (Geographic Information Systems) users; and (3) digital PostScript files of OF-DM plots.

We follow a standard process for the production of our digital map products. Geologic data are compiled from field mapping, aerial photo interpretation, borehole cuttings, correlation of electricalconductivity logs, etc. Geologic line-work (contacts, structures, and symbology) is inked onto a greenline, mylar stable-base and scanned at $100 \%$ at 400 dpi (dots per inch) on an INTERGRAPH ANATECH $^{\otimes}$ large-format drum scanner (courtesy of the USGS-National Cooperative Geologic Mapping Program). The resulting TIFF line-work file is rubber-sheeted to geo-referencing tick marks generated in $\mathrm{ARC} / \mathrm{INFO}^{\circledR}$. This file is exported along with the ticks as an Adobe Illustrator ${ }^{\circledR}$ file to Macintosh Macromedia FreeHand ${ }^{\circledR}$, where the linework is drafted, unit polygons are assigned CMYK (cyan, magenta, yellow, black) colors, and type is set. This process essentially eliminates potential errors introduced by a digitizer-operator, and produces smaller digital files that contain lines with smooth curves made from a minimum number of points (nodes) and offset-printing quality type. We then export the drafted line-work as individual layers for all individual line attributes as DXF files to $\mathrm{ARC} / \mathrm{INFO}^{\circledR}$, where they are converted into ARC coverages for GIS users. We register the completed geologic map FreeHand ${ }^{\circledR}$ file to a TIFF DRG (digital raster graph) quadrangle base (which has been cleaned in Adobe Photoshop ${ }^{\circledR}$ and turned transparent in FreeHand ${ }^{\circledR}$ ). We export the map as a PostScript file to Image Alchemy ${ }^{\circledR}$, which rasterizes the file for inkjet plotting on demand. Through this multi-platform process, we provide the public with superior paper and digital geohydrologic products, we increase NMBMMR's cartographic production efficiency, and we can easily revise NMBMMR's peer-reviewed Geologic Map (GM) series, which are printed by offset press.

Current Open-File Digital Geologic-Quadrangle Maps Available

\begin{tabular}{lcc}
\hline 7.5-Minute Quad & OF-DM \# & Scale (1:--) \\
\hline Sandia Park & 1 & $12 \mathrm{k}, 24 \mathrm{k}$ \\
Placitas & 2 & $12 \mathrm{k}, 24 \mathrm{k}$ \\
Albuquerque East & 3 & $24 \mathrm{k}$ \\
Hubbell Spring & 5 & $12 \mathrm{k}, 24 \mathrm{k}$ \\
Alameda & 10 & $24 \mathrm{k}$ \\
\hline
\end{tabular}




\title{
USING GIS TO PRODUCE A DIGITAL GEOLOGIC MAP: THE LOS LUNAS QUADRANGLE, AN EXAMPLE FROM THE MIDDLE RIO GRANDE BASIN, NEW MEXICO
}

\author{
Janet L. Slate and Nancy A. Shock \\ U.S. Geological Survey, National Cooperative Geologic Mapping Team, \\ Box 25046, MS 913, Denver, CO 80225 \\ <jslate@usgs.gov>
}

The Central Region - National Cooperative Geologic Mapping Team of the Geologic Division of the U.S. Geological Survey is compiling a digital geologic map-database of the Middle Rio Grande Basin, New Mexico. The database will cover the Albuquerque, Belen, and Los Alamos 1:100,000-scale map sheets as well as portions of adjacent 100,000 scale map sheets. The Los Lunas quadrangle, which encompasses the Rio Grande floodplain, is a prototype of the map-database. The map-database will provide geologic, geophysical, and water-well information useful to water-resource engineers and land-use planners.

We obtained the 1:24,000-scale DLG (digital line graph) file of the Los Lunas quadrangle from the Global Land Information System (GLIS) of the USGS National Mapping Division to use as a background during air photo interpretation. (Go to http://edcwww.cr.usgs.gov/Webglis/glisbin/glismain.pl for a list of data sets supported by GLIS.) This initial step circumvents the traditional analog compilation of geology onto a scale-stable mylar base (so-called "green-line mylar"), and allows us to compile geology directly into digital form. We use a computerized photogrammetric mapping system which consists of Carl Zeiss Inc. CADMAP ${ }^{\circledR}$ software and a digital Kern PG-2 stereoplotter. A stereo pair of air photos are mounted on the PG-2 and scaled to the map base such that a location examined in stereo on the air photos corresponds to the same location on the digital map.
Thus geology interpreted from air photos and field work may be transferred precisely to the digital file while viewing the area in stereo. Sample locations, faults, or geologic units may also be compiled in the digital file from a paper or mylar topographic quadrangle map during this procedure. The hardcopy map, which is affixed to a digitizing tablet, is also scaled to the digital map. Existing geologic, fault, soils, or other thematic maps may be brought in as a digital background to aid in compilation. If these are not available digitally, they can be scanned or digitized. Beginning with a digital map base enables us to save time by eliminating the steps taken to convert data from analog to digital.

Accurately placed symbols in the digital geologic map-database show locations of field observations, sampling sites, measured sections, drill holes, and cross sections. Using the mouse of the computer to "click" on the symbol activates the retrieval of supplemental information from the database. Such information includes annotated photographs of important field sites, analytical data of samples, graphical representations of measured stratigraphic sections, drill holes, and cross sections, and downhole or airborne geophysical data where available. We used $\mathrm{ARC} / \mathrm{INFO}^{\circledR}$ and $\mathrm{ArCView}^{\circledR}$ to construct the digital map-database. The digital map products resulting from this study will enable users to easily and quickly access the information they want for the Middle Rio Grande Basin. 


\title{
HISTORICAL MAP RESEARCH FOR THE MIDDLE RIO GRANDE BASIN STUDY
}

\author{
Stewart Wright \\ U.S. Geological Survey, Rocky Mountain Mapping Center, \\ Box 25046, MS 509, Denver, CO 80225
}

\begin{abstract}
Introduction
Many geographic information system (GIS) studies deal with the past as well as the present. Maps produced before the availability of aerial photography (1934) provide an important source of historical geographic information for establishing baseline conditions. Thematic information, such as urban extents and transportation, can be collected from historical maps to analyze man's impact on the land surface through time. More recent editions of historical maps can be used as ancillary data for interpreting landscape change from historical and current aerial photographs.
\end{abstract}

The purpose of this research was to identify historical editions of U.S. Geological Survey (USGS) maps for the Middle Rio Grande Basin Study area. The following parameters were defined: (1) geographic extent of the project; (2) information needed by project personnel to decide which historical maps to use; (3) map series to be researched; (4) map acquisition strategies; and (5) the formats for the research results.

\section{Methodology}

An important source used for this research was Map Index to Topographic Quadrangles of the United States, 1882 - 1940 (Moffat, 1985.) The author describes this book as "a graphic bibliography of out-of-print topographic maps published from 1882 to 1940 in the 15-, 30-, and 60-minute series for all states except Alaska." One section contains a state-by-state list of areas of pre-1940 large-scale (1:24,000- and 1:31,680scale) topographic maps.

The book has an alphabetical published map list and map index for each state. Each map list contains the quadrangle names, survey dates, map scale (expressed by minutes of latitude and longitude), and map-index key numbers. The index maps show the geographic extent of the historical maps and are keyed to the corresponding numbers shown in the published map lists. The map indexes and lists in this book were used to check the completeness of historical map coverage data obtained in the computer-file searches.
Historical copies of USGS topographic map indexes were used for data verification. These indexes usually cover a single state and show the geographic extent of maps at various scales. Most of the indexes consulted were published in the early 1950's.

Records where only the date of printing differs reflect reprints of earlier map editions. Because map content was the same, only one of these versions needed to be acquired.

The first phase of the research involved pre-1934 USGS mapping because information for those maps was already available from the USGS Historical Map Archive database in Reston, Virginia. The data file for this archive contains approximately 12,500 records. All map scales and types, including special maps and advance sheets, were listed. On the basis of the previously defined query parameters, the following information was obtained for each historical map within the Middle Rio Grande Basin Study area: southeast corner latitude-longitude coordinates, map names, scales, and dates of publication, survey, reprint, and revision. This information allows researchers to identify maps produced during specific time periods and those that are simply reprints of earlier editions with no changes in map content.

Data for the second phase of the research were retrieved from the USGS Map Catalog (MAPCAT), which is under development for internal USGS use. Not all historical maps are listed in MAPCAT, and some maps have incomplete field entries. Twenty map-series queries were done for the Middle Rio Grande Basin Study. MAPCAT query results for each historical map included current or historical status, southeast corner latitude-longitude coordinates, map names, scale, map-series identifiers, and dates of publication, survey or field check, reprint, and revision.

The USGS Earth Science Information Centers have microfiche of many historical USGS editions; an investigator could review these to identify which maps would be useful for characterizing man's im- 
pact on the landscape through time. Other potential sources of historical maps are map depositories, such as libraries and educational institutions, historical societies, and state and local government agencies.

\section{Conclusion}

The historical map-query results from the USGS Historical Map Archive and from MAPCAT tables were supplied to the USGS Middle Rio Grande Basin researchers who will decide which historical maps to acquire for characterizing landscape changes in the Middle Rio Grande Basin through time.

Determining the existence of historical maps can be a challenge owing to multiple map archives and different database structures. For efficient searches the following criteria need to be defined: geographic extent of the project, map series or types to be investigated, attributes needed to identify historical maps, and the storage formats for retaining historical map-query results.

\title{
REFERENCE
}

Moffat, R.M., 1985, Map index to topographic quadrangles of the United States, 1882 - 1940: Western Association of Map Libraries, Occasional Paper No. 10.

\section{URBAN DYNAMICS OF THE MIDDLE RIO GRANDE BASIN}

\author{
David J. Hester \\ U.S. Geological Survey, Rocky Mountain Mapping Center, \\ Box 25046, MS 516, Denver, CO 80225
}

\section{Introduction}

Urban dynamics is the study of land transformations occurring in metropolitan areas through time. A new housing subdivision, such as Huning Highlands, or a new shopping center, such as Winrock, are examples of land transformations. Analyzing the rate of land-use change, and calculating increases in population density, housing-unit density, density of the transportation network, and waterconsumption rates are techniques to characterize growth-driven land transformations. Urban growth in the Albuquerque area is resulting in increasing ground-water withdrawal which reduces flow in the Rio Grande (McAda, 1996). Modeling to predict urban growth helps us understand the impact of urbanization on the region's water resources, economy, and people.

\section{Population Growth}

From 1900 to 1990, the population of New Mexico increased from 195,000 inhabitants to 1,515,000 (Chourre and Wright, 1997). The City of Albuquerque contributed 30 percent to New Mexico's population growth during this time. In 1990, the population of the Middle Rio Grande Basin (MRGB) was about 564,000 , which amounted to about 35 percent of the inhabitants of the state of New Mexico (U.S. Department of Commerce, 1991). The Albuquerque area accounts for about 90 percent of the residents of the MRGB. Until the 1970's, growth was greatest in the North Valley and East Mesa of Albuquerque; however, lower land prices drove urbanization to the West Side area in the mid-1980's. The Greater West Side Area, including Rio Rancho and Corrales, accounted for 60 percent of Albuquerque's total urban growth between 1980 and 1995 (Middle Rio Grande Council of Governments, 1997). If Rio Rancho's population continues to increase at the same growth rate, the municipality will soon surpass Santa Fe as the second largest city in New Mexico.

\section{Land Transformations}

From 1970 to 1990, a 1-percent increase in national population resulted in a 6- to 12-percent increase in land use (Middle Rio Grande Council of Governments, 1997). These transformations from land cover to land use have typically meant a decrease in areas conducive to ground-water recharge such as agricultural lands, forestlands, and wetlands. From 1945 to 1992, general land-use trends for the south- 
western U.S. were the transformation of forest and pasture land to transportation, industrial, and urban uses (O'Donnell, 1997). In the Albuquerque area, 14,000 acres were irrigated in 1975, compared to 9,600 acres in 1992 (McAda, 1996). Concomitant with a 30-percent decline in irrigated agriculture, from 1973 to 1991, urbanized land in the Albuquerque metropolitan area grew by about 70 percent or 35,000 acres (Braun and others, 1997).

\section{Water Consumption}

Albuquerque's annual ground-water withdrawal has increased from about 2,000 acre-feet in 1933 to about 123,000 acre-feet in 1994, with more than 50 percent of the withdrawal occurring from 1980 to 1994 (McAda, 1996). New high-technology industries, for example, Intel's Rio Rancho plant which consumed nearly 4-million gallons per day in 1996, place a high demand on existing ground-water resources. Natural resources, such as water, sustain an urban area's economic and population growth. The availability, collection costs, and distribution of water resources influence future land-use patterns.

\section{Urban-Growth Modeling}

An urban-growth model (UGM) can be used to predict future urbanization. The UGM produces both quantitative data and a pictorial view of predicted urban expansion. The USGS-NMD plans to use the UGM for a pilot area in the MRGB encompassing Albuquerque, Rio Rancho, Edgewood, and Mori- arty. The UGM requires datasets of historical urban extent, slope, historical roads, areas excluded from development, and shaded relief. The UGM incorporates four types of growth-spontaneous, diffusive, organic, and road-influenced-as well as five growth parameters and five growth constants (Clarke et al., 1996a, 1996b). Aerial photographs from 1935, 1951, 1973, and 1996 will be interpreted to map historical urban extent and to calibrate model output. Calibration is an iterative process; that is, actual growth in each successive aerial photo is compared with that predicted by the UGM. Initial growth values are then modified such that predicted urban area matches actual urban area recorded in the aerial photographs. Once calibration is complete, the UGM can predict future urbanization for a time period similar to that of the historical data.

\section{Conclusion}

From 1891 to 1995, the developed Albuquerque metropolitan area increased from 2000 acres to 103,000 acres (Price, 1996). Public and Indian lands cover approximately 40 percent, or 3,900 square miles, of the MRGB (Middle Rio Grande Council of Governments, 1997) which will likely constrain future urban growth. The USGS-MRGB urban-growth modeling will help identify areas of future urbanization and analyze the potential impacts of the resulting urban-land transformation.

\section{REFERENCES}

Braun, Paul, Chourre, Martin, Hughes, Dave, Schubert, Jamie, Streibek, Heike, and Thorstad, Rick, 1997, Land use change in the Albuquerque Metropolitan Area: U.S. Geological Survey, $\mathrm{http} / / / \mathrm{geochange.er.usgs.gov/sw/changes/anthropogenic/albuquerque/.}$

Chourre, Martin, and Wright, Stewart, 1997, Population growth of the Southwest United States, 1900-1990: U.S. Geological Survey, http://geochange.er.usgs.gov/sw/changes/anthropogenic/population/.

Clarke, K.C., Hoppen, S., Gaydos, L., 1996a, Methods and techniques for rigorous calibration of a cellular automaton model of urban growth, Third International Conference/Workshop on Integrating GIS and Environmental Modeling: Santa Fe, New. Mexico, National Center for Geographic Information and Analysis, University of California, Santa Barbara.

Clarke, K.C., Hoppen, S., Perez, S., 1996b, Clarke Urban Growth Model: U.S. Geological Survey, http://geo.arc.nasa.gov/usgs/clarke/hilt.html.

McAda, D.P., 1996, Plan of study to quantify the hydrologic relations between the Rio Grande and the Santa Fe Group Aquifer System near Albuquerque, central New Mexico: U.S. Geological Survey Water-Resources Investigations Report 96-4006, $58 \mathrm{p}$.

Middle Rio Grande Council of Governments, DRAFT October 15, 1997, FOCUS 2050 snapshot: Existing conditions, significant trends, and projections in the Middle Rio Grande Region: Albuquerque, New Mexico, $34 \mathrm{p}$.

O'Donnell, Michael, 1997, Land use trends in the southwestern United States: U.S. Geological Survey, $\mathrm{http} / /$ geochange.er.usgs.gov/sw/changes/anthropogenic/cropland/.

Price, V.B., 1996, Albuquerque's environmental story-People create their own environment: Albuquerque, New Mexico, http://www.cabq.gov/aes/s2arch.html. 
U.S. Department of Commerce, 1991, 1990 census of population and housing; Summary population and housing characteristics, New Mexico: 1990 CPH-1-33, variously paged.

\title{
MIDDLE RIO GRANDE COUNCIL OF GOVERNMENTS LAND-USE ANALYSIS MODEL
}

\author{
Mike Corlett ${ }^{1}$ and David Abrams ${ }^{2}$ \\ ${ }^{1}$ Planning Technologies, LLC, \\ 6801 Jefferson, N.E., Suite 100, Albuquerque, NM 87109 \\ ${ }^{2}$ Middle Rio Grande Council of Governments, \\ 317 Commercial, N.E., Suite 300, Albuquerque, NM 87102
}

We designed a model, called the Land Analysis Model (LAM), to allocate forecast population and employment growth to a conceptual land-use plan. Planning Technologies and their subcontractor, Earth Data Analysis Center (EDAC), built the model in ArcView ${ }^{\circledR}$ to Middle Rio Grande Council of Governments (MRGCOG) specifications. It is being built to support the Focus 2050 Regional Plan but should have applications for other planning activities, especially area studies and corridor studies.

Currently the Focus 2050 region has a population of approximately 700,000 with an employment of 350,000 . The MRGCOG has forecast that the region will grow to a population of $1,555,000$ and an employment of 854,000 by 2050 (MRGCOG, 1997). The average, annual-population growth rate is forecast at about 1.5 percent.
We gave a demonstration of LAM at the Middle Rio Grande Basin Study Workshop, on February 10, 1998, which illustrated the following features:

(1) Construction of alternative land-use scenarios;

(2) Development of a known developments layer to enhance the Existing Land Use;

(3) Development and operation of scoring layers within LAM;

(4) Allocation of projected housing and employment constrained by regional control totals;

(5) The iterative functioning of LAM; and

(6) Output from LAM.

We can process housing and employment outputs from LAM to develop a socioeconomic data set including population, housing, and employment by type. This socioeconomic data set can be input into other models such as transportation models.

\section{REFERENCE}

Middle Rio Grande Council of Governments, 1997, Socioeconomic Estimates and Forecasts to 2050 for State Planning and Development District 3 and Southern Santa Fe County: Middle Rio Grande Council of Governments TR-127, Albuquerque, New Mexico. 


\title{
MIDDLE RIO GRANDE COUNCIL OF GOVERNMENTS EXISTING LAND-USE INVENTORY
}

\author{
Shohreh Day and Carol S. Harlan \\ Middle Rio Grande Council of Governments \\ 317 Commercial, N.E., Suite 300, Albuquerque, NM 87102
}

The Middle Rio Grande Council of Governments (MRGCOG) of New Mexico is spearheading Focus 2050, a land-use planning effort that will produce a long-range vision and strategy for managing growth and development in the region. The Focus 2050 region includes Bernalillo, Sandoval, Torrance, and Valencia Counties, and southern Santa Fe and northern Socorro Counties. Planning Technologies, LLC, and Earth Data Analysis Center developed a geographic information system (GIS) Land-Use Analysis Model (LAM) using ArcView ${ }^{\circledR}$ software to construct various alternative future land-use scenarios and to allocate forecast socioeconomic variables. The MRGCOG is working cooperatively with the National Mapping Division, U.S. Geological Survey in Denver on land-use and land-surface characterization aspects of the Middle Rio Grande Basin Study. National Mapping Division provided aerial photography, base maps and slope analyses in support of the Focus 2050 Regional Plan.

An Existing Land-Use Inventory (ELUI) for the entire region was created to support the LAM scenario-development module and the public-input components of the regional planning process. We classified 18 land-use categories. The ELUI reflects land use in the region for the period from late 1996 to early 1997. The ELUI was developed in ARC/INFO ${ }^{\circledR}$ using a combination of digital and analog sources, and a variety of GIS analysis tools.

The three primary digital sources for the ELUI included: (1) City of Albuquerque Geographic Information System (AGIS) digital land-use data, December 1996; (2) U.S. Department of Interior, Bureau of Reclamation Land-Use Trend Analysis (LUTA) data for the years 1992-1993; and (3) digital orthophotography for Bernalillo County acquired in March and May of 1996. The LUTA data utilized 35 land-use classes of which approximately 20 related to crop or vegetation cover. The AGIS data used more than 600 land-use categories. We converted these two sources to the ELUI classes with correspondence tables. Aerial photography and land-use maps were used for compilation and updating, using both manual techniques and "heads-up" digit- izing. Local government planners, zoning administrators, and rural addressing personnel assisted in the inventory and review of data. We collected and verified a limited amount of field data when necessary.

GIS tools assisted in customizing the initial land-use polygon coverage for input to the LAM. MRGCOG planners required that major regional centers (employment and/or commercial) be distinguished in the inventory. Seven regional centers were identified and outlined on land-use plots. Parking areas within these regional center boundaries were reclassified to conform to their abutting polygon land-use classes. Subsequently, all polygons of office and major retail ELUI classes falling outside of regional center boundaries were changed to the mixed/minor commercial ELUI class. The polygon coverage was converted to a raster format using ARC GRID, and all street and railroad right-of-way (ROW) cells were recalculated to the ELUI class of a non-ROW neighbor. We converted this GRID coverage to polygons, and only major street and railroad ROW were added back into the coverage with buffering and overlay processes in $\mathrm{ARC} / \mathrm{INFO}^{\circledR}$. We added housing and employment densities to each polygon by ELUI class based on 1996 socioeconomic data for the 668 Data Analysis Subzones in the region.

Future land-use scenarios and constraint or scoring layers will be developed using LAM modules. Constraint layers define areas where land use such as employment or housing would be unlikely or constrained; one example might be slopes greater than $30 \%$. Scoring layers "score" a polygon based on its desirability for development. The model will then allocate forecast housing and employment based on these layers and constrained by regional controls. A new ArcView ${ }^{\circledR}$ shape file with housing and employment densities is produced from which other necessary socioeconomic variables can be generated for input to transportation, air quality or other models. 


\title{
DATA PRODUCTION STATUS FOR THE MIDDLE RIO GRANDE BASIN
}

\author{
Laurie Davis \\ U.S. Geological Survey, Rocky Mountain Mapping Center, \\ Box 25046, MS 516, Denver, CO 80225
}

Recent investigations of the Albuquerque basin by the U.S. Geological Survey (USGS) and federal, state, and local agencies have determined that the aquifer system is not as extensive as previously thought. This finding has resulted in a concerted effort by federal, state, and local agencies to gather and interpret additional hydrologic, geologic, and geographic data to better manage the important water resources of the Middle Rio Grande Basin.

The USGS established a team to conduct research required for the next 5 years (FY 1996-2000) and to coordinate these efforts with federal, state, and local agencies. One role of the USGS National Mapping Division (NMD) is to provide base cartographic data in support of the Middle Rio Grande Basin study. Currently, the 126-quadrangle project area has complete coverage for the following products:

(1) 7.5-minute 30-meter digital elevation models (DEM);

(2) 1:24,000-scale digital line graph (DLG-3) data for hydrography, cultural features, transportation, the Public Land Survey System, and the quad boundary;

(3) 1:24,000-scale digital raster graphics (DRG); and

(4) 1:40,000-scale black-and-white aerial photographs (NAPP).

To identify additional requirements for base cartographic data, a Middle Rio Grande Basin solicitation package was distributed in January 1997 to more than 40 federal, state, and local agencies working in New Mexico. The base cartographic data offered in the solicitation package were black-and-white, 1meter-resolution digital orthophoto quadrangles (DOQ), 7.5-minute 10-meter DEM, and limited update revision of the DLG-3 categories mentioned above. Seven responses were returned in February 1997. Three Department of the Interior (DOI) bureaus submitted responses through the DOI HighPriority Digital Base Data Program solicitation.

The purpose of the Middle Rio Grande Basin solicitation was to ensure the most efficient use of available funding and production resources to satisfy requirements for base cartographic data. NMD evaluated the responses and developed a selection process based on two criteria: (1) data requested needed to be used in support of the Middle Rio Grande Basin study; and (2) data requests from multiple agencies must be overlapping. After evaluating the responses, NMD developed the following base cartographic production plan.

\section{Digital Orthophoto Quads (DOQ)}

Through the DOI High-Priority Digital Base Data Program and USGS internal funding sources, and in partnership with the U.S. Forest Service, 119 quadrangles (476 quarter-quadrangles) are authorized for DOQ production. Digital orthophoto quads will be produced using the 1996 NAPP photographs for all quadrangles except: Mesa Sarca, Comanche Ranch, Mountainair, Willard, Ladron Peak, Mesa Draw, and Round Top. Scheduled completion date is January 1999.

\section{Digital Elevation Models (DEM)}

The entire 126-quadrangle project area is currently authorized for 10-meter DEM production. Scheduled completion date is March 1998.

\section{Digital Line Graphs (DLG-3)}

Seventy-five 1:24,000-scale quadrangles are currently authorized for DLG-3 hypsography collection to provide complete contour coverage for the project area. Scheduled completion date is March 1998.

\section{Limited update revision of DLG-3 data files}

Evaluation of the Middle Rio Grande Basin solicitation responses identified eighty 1:24,000-scale quadrangles where limited update revision of DLG-3 data files was requested. The NMD team photoinspected 14 of those quadrangles to determine which DLG-3 overlays would require digital limited-update (DLU) revision. Photo-inspection showed that four quadrangles required no DLU revision, four quadrangles required transportation revision, and six quadrangles required DLU revision for both transportation and cultural features. NMD will do the DLU revision for these 1:24,000scale DLG-3 overlays in fiscal year 1998. NMD has yet to resolve how the remaining 66-quadrangle 
DLU requirement will be met during fiscal year 1998.
File transfer protocol (ftp) will be used to distribute data in response to each solicitation except for DOQ, which will be distributed on 8-mm tape.

\title{
DESIGN AND DEVELOPMENT OF THE MIDDLE RIO GRANDE BASIN STUDY WEB PAGES
}

\author{
Mark R. Feller \\ U.S. Geological Survey, Rocky Mountain Mapping Center, \\ Box 25046, MS 516, Denver, CO 80225
}

The Middle Rio Grande Basin (MRGB) study web site enables those involved with the project to disseminate information about the hydrology, geology, and land-surface characteristics of the region. The web site is a centralized location, accessed via the Internet, where study results are readily available.

The software tools used to develop the individual pages included various software packages for webpage publishing, multiple search engines to locate appropriate links to relevant sites, an interactive image display and editing tool for an X Windowing system, and the Gnu Emacs editor with multiple ELISP (emacs interpreted programming language) macros. Various browsers were used for testing the look and feel of the individual web pages developed. The browsers used during the testing phase were Internet Explorer version 2.0, Internet Explorer version 3.02, Netscape Navigator 2.0, Netscape Navigator 3.01 Gold, Netscape Communicator 4.02, Mosaic version 2.4, and Mosaic version 2.7. The hardware used in developing and testing the software consisted of personal computers, Data General workstations and servers, and a Howtek scanner. The server that hosts the Middle Rio Grande Basin web pages is a Data General Aviion 6240 . This machine has four 22 megahertz processors with 96 megabytes of RAM (random access memory), along with 8 gigabytes of storage. The version of the software used for making hypertext and other documents available to web browsers is NCSA's HTTPD version 1.5. The server that hosts the pages is located at the U.S. Geological Survey (USGS), Rocky Mountain Mapping Center (RMMC) in Denver, Colorado. (Any use of trade, product, or firm names is for descriptive purposes only and does not imply endorsement by the U.S. Government.)
The guidelines followed for the general layout of the web pages are published in the document USGS Data and Publications on the Internet World Wide Web. This document was approved by all areas within the USGS that develop web pages. The page design for the Middle Rio Grande Basin study uses frames that allow individual areas within a page viewed on a screen to take on their own characteristics. One of the main goals for the Middle Rio Grande Basin web site was to provide the capability for anyone to access the information on the web site, whether the user's browser supported frames or not. Therefore, parallel development was required, allowing both the browsers that did not have frame functionality and those that did to view the same content of the web pages. Each web page was developed to allow the user to return to the Middle Rio Grande Basin home page and to send any comments, criticism, or information to the USGS Middle Rio Grande Basin study project manager. When the general presentation of the web pages was being considered, multiple browsers with multiple hardware configurations were taken into account.

The base content used for the web pages was the Middle Rio Grande Basin Study Fact Sheet FS-034 published in March 1997. There are nine main information pages under the home page. Each of the nine pages concerns a question discussed in the fact sheet. Each of these main pages can be reached at any time by clicking on the appropriate button on the left side of the web page. Other information linked to the web pages gives the user the option to view documents that support the fact sheet.

For example, an electronic copy of the publication, Simulation of Ground-Water flow in the Albuquerque Basin, central New Mexico, 1901-1994, with Projections 
to 2020 (USGS Water-Resources Investigations Report 94-4251), can be viewed from the web pages. This publication discusses why the study is necessary, describes how the results of these projects will be used, and shows references cited. From the References Cited web page the user can retrieve an electronic copy of USGS MRGB Study--Proceedings of the First Annual Workshop (USGS Open File Report 97-116), and the publication, Plan of Study to Quantify the Hydrologic Relations between the Rio Grande and the Santa Fe Group Aquifer System near Albuquerque, central New Mexico (USGS WRIR 96-4006). The web page links to other governmental agencies involved in studying the water resources in the basin. These include: City of Albuquerque, New Mexico Office of the State Engineer, New Mexico Bureau of Mines and Mineral Resources, Bureau of Reclamation, several Pueblos within the study area, Bernalillo County, New Mexico Environment Department, Sandia National Laboratories, Los Alamos National Laboratory, U.S. Environmental Protection Agency, U.S. Army Corps of Engineers, and Middle Rio Grande Basin Technical Advisory Committee. From the web page that contains facts on what projects will be completed under the study, the user can access the home pages of three divisions within the USGS, along with links to the digital line graph (DLG), digital elevation model (DEM), and digital orthophoto quadrangle (DOQ) programs. From this same page the user can also visit the New Mexico Resource Geographic Information System Program and the U.S. Geological Survey's airborne geophysical surveys web sites. Graphics files explaining the status of geologic mapping in the basin are also available from the web page that discusses which projects will be completed under the Middle Rio Grande Basin study. Within the web page that contains sources of additional information are links to the New Mexico Water Resources District Chief for water information, the RMMC chief for mapping information, and the USGS Central Regional geologist for geologic information, along with the USGS Middle Rio Grande Basin study Coordinating Committee and Technical Advisory Committee.

There are many opportunities for development within the web site. For example, animated graphic image format files could be used to display historical data compiled in the study or possibly to show forecasts of model results. Movies, such as Aquifer Dynamics of the Middle Rio Grande Basin, could also reside on the web pages. Presentations and demonstrations could be recorded and put on the web for viewing. There are plans to incorporate image maps that will allow the user to click on a 1:24,000-scale quadrangle within the Middle Rio Grande Basin study area. Different types of information, such as DLG and DEM data availability, horizontal and vertical datums used for the USGS basecartographic data products, and vintage USGS 1:24,000-scale topographic maps within the basin, could then be accessed. The Internet efficiently disseminates information to the public, and the USGS is taking advantage of this form of electronic media to keep the public informed about the Middle Rio Grande Basin study. 


\title{
NEW MEXICO'S STATEMAP PROGRAM: GEOLOGIC QUADRANGLE MAPPING ALONG THE RIO GRANDE WATERSHED
}

\author{
Paul Bauer \\ New Mexico Bureau of Mines and Mineral Resources, \\ 801 Leroy Place, Socorro, NM 87801 \\ $<$ bauer@nmt.edu>
}

During the first five years of the New Mexico Bureau of Mines and Minerals Resources (NMBMMR) STATEMAP program, we will have mapped 267.5 minute quadrangles along the Rio Grande urban corridor between Taos and Belen (Fig. 17). In June of 1998, we begin work on 10 more quadrangles. The final products are digital, detailed geologic maps (1:24,000 and 1:12,000), with accompanying unit descriptions, cross sections, stratigraphic sections, and explanatory texts. Each quadrangle emphasizes bedrock lithology and structure, and surficial-basin and arroyo-valley deposits, and their importance to ground-water resources and land-use planning. Due to the geologic complexity of the mountain-front areas, we use a multidisciplinary approach to mapping, which utilizes specialists for various aspects of the project, including geoscientists from the NMBMMR, New Mexico Tech, University of New Mexico, and the private sector.
These quadrangles were selected based on their potential to provide high-quality earth-science data to potential users. The Rio Grande corridor is of vital economic, social, and scientific welfare to the state. The important societal needs that we have identified along the Rio Grande watershed are:

(1) Environmental-(a) ground-water and surfacewater supply, availability, and quality; (b) geologic hazards such as flooding, hydrocompaction, and slope stability;

(2) Earth resources-metallic minerals, industrial minerals, aggregate, rock resources;

(3) Land-use planning-landform dynamics, soil properties, water rights, etc.; and

(4) Transportation.

A combination of rapid population growth, permeable alluvial aquifers, large topographic relief, and the alternating scarcity and abundance of meteoric

\begin{tabular}{|c|c|c|c|c|c|}
\hline $\begin{array}{l}\text { Fiscal } \\
\text { year }\end{array}$ & $\begin{array}{l}\text { STATEMAP \$ } \\
\text { available }\end{array}$ & $\begin{array}{l}\text { NMBMMR } \\
\text { \$ awarded }\end{array}$ & $\begin{array}{l}\% \text { of } \\
\text { total }\end{array}$ & Quad(s) mapped & $\begin{array}{l}\text { Average } \\
\$ / \text { quad }\end{array}$ \\
\hline 1993-4 & $\$ 1,442,734$ & $\$ 20,000$ & 1.4 & Tijeras & $\$ 20,000$ \\
\hline $1994-5$ & $\$ 1,979,641$ & $\$ 50,000$ & 2.5 & Albuquerque East, Sandia Crest, Placitas & $\$ 16,667$ \\
\hline 1995-6 & $\$ 1,287,000$ & $\$ 50,000$ & 3.9 & $\begin{array}{l}\text { Sandia Park, Hubbell Spring, McClure } \\
\text { Reservoir }\end{array}$ & $\$ 16,667$ \\
\hline 1996-7 & $\$ 4,376,400$ & $\$ 165,330$ & 3.8 & $\begin{array}{l}\text { Isleta, Alameda, Mt. Washington, Sky } \\
\text { Village SE, Jemez Pueblo, Santo Do- } \\
\text { mingo Pueblo, Glorieta, Taos SW }\end{array}$ & $\$ 23,619$ \\
\hline $1997-8$ & $\$ 3,708,814$ & $\$ 157,421$ & 4.2 & $\begin{array}{l}\text { Bernalillo, Albuquerque West, San Ysi- } \\
\text { dro, San Felipe Pueblo, Sedillo, Dalies, } \\
\text { Carson, Seton Village, Bosque Peak, } \\
\text { Loma Creston, Santo Domingo Pueblo } \\
\text { SW }\end{array}$ & $\$ 17,491$ \\
\hline $1998-9$ & $\$ 3,762,798$ & $\$ 150,000$ & 4.0 & $\begin{array}{l}\text { San Pedro, Edgewood, San Felipe Pueblo } \\
\text { NE, Galisteo, Santa Fe, Veguita, Socorro, } \\
\text { Ranchos de Taos, Rosilla Peak, Capilla } \\
\text { Peak }\end{array}$ & $\$ 15,000$ \\
\hline
\end{tabular}


NM Bureau of Mines \& Mineral Resources

Dr. Charles E. Chapin, Director

Dr. Paul W. Bauer, Geologic Mapping Program Manager

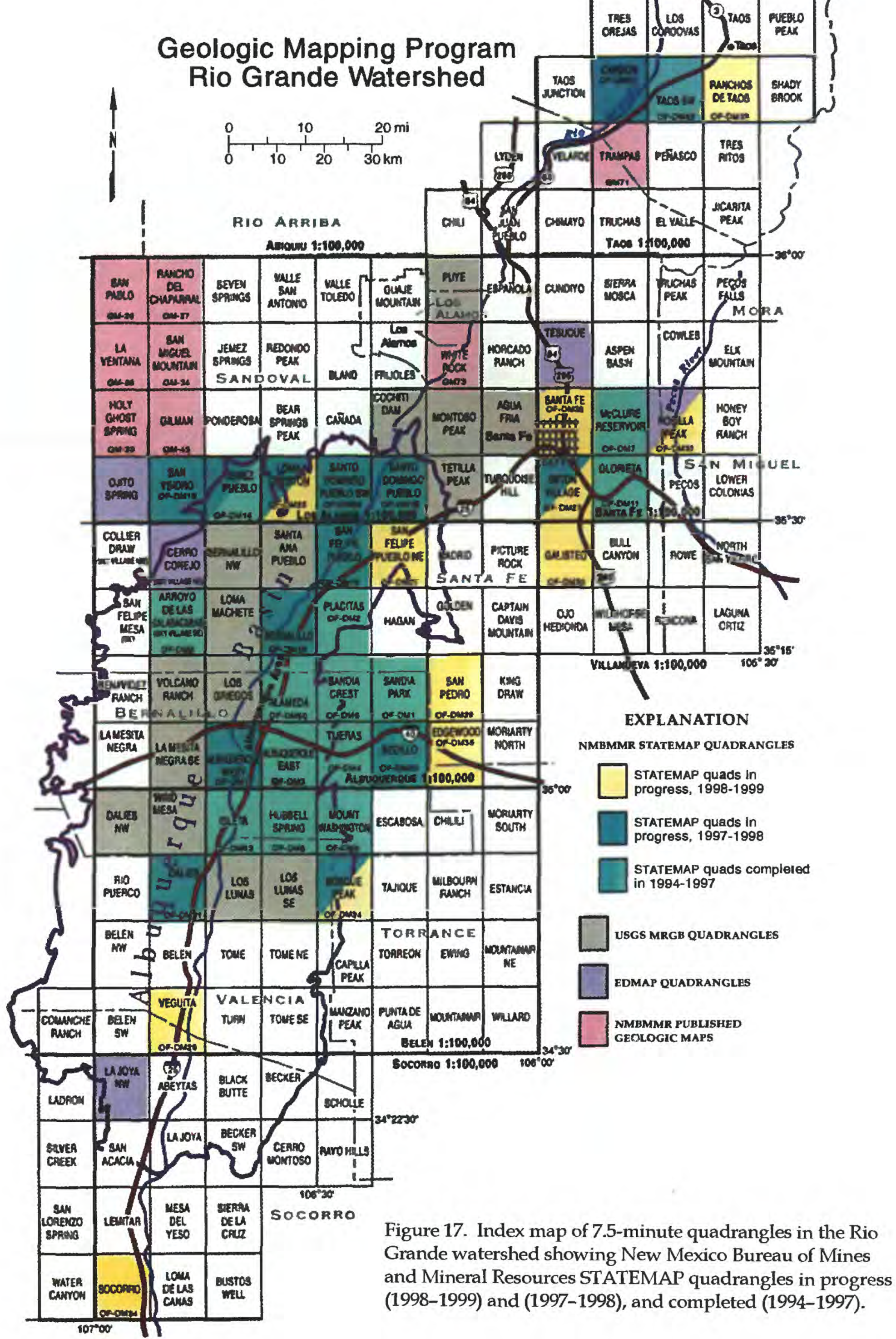


water gives rise to a host of hydrogeologic and engineering geologic problems. The Albuquerque, Española, San Luis, and Socorro basins and adjacent uplifts have become the focus of geologic and hydrologic interest by local, state, tribal, and federal officials due to concern over the supply of ground water for an expanding population. Understanding watersheds and basin-fill stratigraphy is critical to ensure potable water for the future, and to mitigate aquifer contamination. Surficial deposits provide critical data on flood-prone zones, areas subject to mass wasting, and soil and sediment parameters that influence construction plans and land management. Geologic structures also control groundwater flow; in particular, the hydrogeologic significance of both rift-related normal faults and transverse fault zones needs quantifying. Several of the quadrangles also contain rocks (Proterozoic to Cenozoic in age) that are the focus of topical, ongoing investigations in rock and mineral resources, structural geology, stratigraphy and sedimentology, basin evolution, and tectonics. Furthermore, the maps will benefit government bodies (state, county, tribal, local) and private organizations (environmental, planners, developers, citizens groups). The NMBMMR has actively cultivated working relationships with such groups, all of which have expressed a need for detailed geologic maps. The NMBMMR and the State Geologic Mapping Advisory Board, which consists of 30 members from federal, state, county, municipal, tribal, and private agencies, are responsible for setting mapping priorities in New Mexico.
The overall project objective is to characterize the geology of each area in sufficient detail to allow use of this information in matters of practical economic and environmental concern to governments, communities, and planners, as well as to satisfy the fundamental goals of basic science. In addition, we will continue to integrate information from individual quads into an ever-expanding regional synthesis of stratigraphy, structure, hydrogeology, and engineering geology. This multidisciplinary approach to mapping and subsurface investigations in one of the most rapidly growing regions in the southwestern U.S. will serve the multiple goals (social, economic, scientific) of the National Geologic Mapping Program and the people of New Mexico.

We work closely with USGS-Geologic Division personnel involved in the Middle Rio Grande Basin Project, and expect most of our maps will be used in the USGS 1:100,000 compilation of the Albuquerque Basin. Several of our quads dovetail with EDMAP projects sponsored by professors at New Mexico Tech and UNM. Some of our quads compliment cooperative investigations, such as ongoing hydrogeologic studies with the Office of the State Engineer and Sandoval County.

Our STATEMAP geologic maps have significantly increased our understanding of the bedrock geology, surficial deposits, hydrogeology, and subsurface stratigraphy and structure of the Rio Grande rift basins and uplifts. Agency personnel who address environmental, water-resource, and landplanning issues value our maps. 


\title{
NEW MEXICO DISTRICT COOPERATIVE PROGRAM IN THE MIDDLE RIO GRANDE BASIN, FY98
}

\author{
Dennis G. Woodward \\ U.S. Geological Survey, Water Resources Division, \\ 4501 Indian School Road, N.E., Suite 200, Albuquerque, NM 87110
}

The New Mexico District of the U.S. Geological Survey (USGS) has established and fostered for many decades a dynamic Federal-State Cooperative Program in the Middle Rio Grande Basin, central New Mexico. In the Cooperative Program, investigative projects and data-collection activities are jointly identified, planned, and funded by the USGS (as much as 50 percent) and by State and local agencies. Generally, the State and local agencies provide at least one-half the funds, and the USGS does most of the work. The collective results of the Cooperative Program have provided the scientific basis and the institutional framework for developing the USGS Middle Rio Grande Basin Study that began in fiscal year 1996. This article briefly describes the historical highlights of the Cooperative Program in the Middle Rio Grande Basin and the components of the present program. Of the approximate $\$ 4.5$ million allocated in fiscal year 1998 for USGS work in the basin, about $\$ 1.6$ million was from the Cooperative Program. The major agencies in the Cooperative Program in the basin study are the City of Albuquerque (City), the New Mexico Office of the State Engineer Office (NMOSE), and Bernalillo County.

One of the earliest highlights of the Cooperative Program in the Middle Rio Grande Basin was the report on the availability of ground water in the Albuquerque area by Bjorklund and Maxwell (1961). They presented regional maps of the geology and water-table configuration in the area. Reeder and others (1967) provided a quantitative analysis of the water resources in the Albuquerque area, with computed effects on the Rio Grande from ground-water pumpage. They presented projected water-table declines and depletions of Rio Grande flow due to projected ground-water withdrawals. Following a period primarily devoted to datacollection activities, the development, construction, and documentation of the Albuquerque Basin ground-water-flow model rank as a recent significant milestone in the Cooperative Program with the City of Albuquerque. Thorn and others (1993) described the geohydrologic framework and hydrologic conditions used in the flow model, and Ker- nodle and others (1995) presented the results of the flow model. McAda (1996) detailed a plan of study to quantify the hydrologic relations between the Rio Grande and the Santa Fe Group aquifer system in the Albuquerque area; 13 essential activities and informational needs were identified and prioritized. The most recent highlight of the Cooperative Program with the City is the drilling and completion of a series of nested piezometers located throughout the Albuquerque area. By the end of calendar year 1997, 11 piezometer nests - each with three piezometers-were completed at nine different sites. Generally, the nests have piezometers that measure water levels near the water table, near the middle of the "production zone" in the City wells, and near the base of the "production zone" in the City wells.

The current (1998) Cooperative Program with the City contains the following components: (1) continuation of the ground-water-level monitoring network; (2) expansion of the monitoring network by completion of more nested piezometers; (3) estimation of surface-water depletions from the Rio Grande resulting from ground-water withdrawals results from model simulations will be compared to results from the Glover-Balmer (1954) method; (4) estimation of seepage rates from the Rio Grande, canals, and drains in the Albuquerque area; (5) monitoring of low-flow conditions in urban storm drains; (6) Rio Grande flood-pulse investigation; (7) determination of mountain-front recharge by chloride-balance methods; (8) assessment of waterquality trends in City production wells; (9) dissemination of hydrologic information over the Internet: (10) update of the regional ground-water-flow model; (11) assistance to the Upper Rio Grande Water Operations Model; and (12) investigation of aquifer compaction and land subsidence. Many of these activities focus on quantifying hydrologic relations between the Rio Grande and the aquifer system, as identified in the McAda (1996) plan. The current (1998) Cooperative Program with the NMOSE contains the following components: (1) revision of the Albuquerque Basin ground-waterflow model; (2) participation in the estimation of physical and hydraulic characteristics of canals and 
drains; (3) participation in the drilling and completion of the nested piezometers network; (4) participation in a large-scale aquifer test in Albuquerque; and (5) continuation of the long-term ground-water- level monitoring network. The 1998 Cooperative Program with Bernalillo County provides for the drilling and completion of a series of deep-nested piezometers.

\title{
REFERENCES
}

Bjorklund, L.J., and Maxwell, B.W., 1961, Availability of ground water in the Albuquerque area, Bernalillo and Sandoval Counties, New Mexico: New Mexico State Engineer Technical Report 21, 117 p.

Glover, R.G., and Balmer, G.G., 1954, River depletions resulting from pumping a well near a river: EOS, Transactions, American Geophysical Union, v. 35, no. 3, p. 468-470.

Kernodle, J.M., McAda, D.P., and Thorn, C.R., 1995, Simulation of ground-water flow in the Albuquerque Basin, central New Mexico, 1901-1994, with projections to 2020: U.S. Geological Survey Water-Resources Investigations Report 94-4251, 114 p., 1 pl.

McAda, D.P., 1996, Plan of study to quantify the hydrologic relations between the Rio Grande and the Santa Fe Group aquifer system near Albuquerque, central New Mexico: U.S. Geological Survey Water-Resources Investigations Report 96-4006, $58 \mathrm{p}$.

Reeder, H.O., Bjorklund, L.J., and Dinwiddie, G.A., 1967, Quantitative analysis of water resources in the Albuquerque area, New Mexico-Computed effects on the Rio Grande of pumpage of ground water, 1960-2000: New Mexico State Engineer Technical Report 33, $34 \mathrm{p}$.

Thorn, C.R., McAda, D.P., and Kernodle, J.M., 1993, Geohydrologic framework and hydrologic conditions in the Albuquerque Basin, central New Mexico: U.S. Geological Survey Water-Resources Investigations Report 93-4149, 106 p.

\section{MEMORANDUM OF UNDERSTANDING BETWEEN THE U.S. GEOLOGICAL SURVEY - NATIONAL MAPPING DIVISION AND THE MIDDLE RIO GRANDE COUNCIL OF GOVERNMENTS OF NEW MEXICO}

\author{
Lee W. Aggers ${ }^{1}$, Stephen J. Burstein ${ }^{2}$, and David J. Hester ${ }^{1}$ \\ ${ }^{1}$ U.S. Geological Survey, Rocky Mountain Mapping Center, \\ Box 25046, MS 516, Denver, CO 80225 \\ ${ }^{2}$ Middle Rio Grande Council of Governments, \\ 317 Commercial, N.E., Suite 300, Albuquerque, NM 87102
}

This Memorandum of Understanding (MOU) between the U.S. Geological Survey (USGS), National Mapping Division (NMD), and the Middle Rio Grande Council of Governments (MRGCOG) of New Mexico was signed on June 18, 1997. An official copy of the signed MOU may be requested from either individual listed under the "Points of Contact" section. Due to abstract limitations, the following summary has omitted the definitions, implementation plan, superseded agreements, and approval sections from the original signed MOU.

\section{Purpose}

This MOU is established between the USGS, NMD, and the MRGCOG (known as the partner agency) to provide the capability to share various geographic data, and to foster mutual land-use modeling applications. This MOU will facilitate the transfer of technology, the exchange of digital and hardcopy geographic data, and the joint development of methods for land use analysis.

\section{Objectives}

1. To promote a shared cooperative partnership that will mutually benefit both agencies participating in joint land-use/land-cover and landsurface characterization research and development.

2. To provide a mechanism for coordination, production, and exchange of analog mapping products, digital cartographic data, and re- 
motely sensed data to be used by the MRGCOG and the USGS for land-use analysis.

3. To exchange geospatial data, geoprocessing technologies, and modeling methods for landsurface analysis research.

4. To mutually enhance the ability to transfer products and technology, and to support the use and application of geospatial data for landuse modeling.

\section{Background}

USGS

As the principal national mapping agency of the United States, one of the missions of the USGS is to produce, update, and disseminate geographic, cartographic, remotely sensed, and related earthscience information in graphic and digital form. The USGS is involved in the Middle Rio Grande Basin (MRGB) Study, which is a cooperative interdivisional and interagency effort to improve quantitative understanding of water availability in the Albuquerque-Santa Fe urban corridor. The objective of the study is to provide critical earthscience information and analysis tools to help municipal officials with future land-use and waterresources planning.

The role of NMD in the MRGB Study consists of producing base cartographic data in the project area, working with cooperating agencies to characterize the land surface, and creating the infrastructure for management of MRGB geospatial data. Since the MRGCOG is developing a land-use analysis model (LAM) for its area of interest (covers approximately 90 percent of the MRGB Study), the USGS is interested in cooperating with the MRGCOG as the model is developed. This effort will assist the USGS in future work with cooperators interested in land-surface characterization.

\section{MRGCOG}

The MRGCOG is a voluntary association of counties, municipalities, and other local governments and organizations in State Planning and Development District 3. As a planning organization, the MRGCOG directs various programs of regional systems planning and gives technical assistance to member organizations.

The MRGCOG has recognized the need for a regional land use plan. The goal of the plan is to produce a long-range strategy for managing growth in the region during the next 50 years. Therefore, the MRGCOG has contracted for the production of de- tailed visualization studies of urban design and rural character as support documents for the Focus 2050 Regional Plan. Because of the USGS's interest in modeling land use, the MRCGOG will work cooperatively with the USGS as the LAM is developed.

\section{Scope}

This Memorandum of Understanding is an agreement between the USGS and the MRGCOG that sets forth basic policies and procedures governing matters of mutual interest and responsibility. Under this agreement, activities include, but are not limited to, base cartographic data collection (such as cost-share, work-share, or data-exchange), regional plan and (or) land-surface characterization database development, participation on regional landuse committees, technical assistance in deriving land-use data, and training for land-use analysis software. This agreement covers production and exchange of geospatial data, technical assistance for land-use analysis, joint development and exchange of land-use analysis software, and review of landuse and land-cover classification standards.

\section{Authorities and Policies}

This agreement is entered into under the following authority:

1. Authorizing Legislation of the USGS (P.L. 100, March 7, 1928), which directs that the Geological Survey's share in any topographic mapping or water-resources investigations carried out in cooperation with any state or municipality shall not exceed 50 percent of that cost (43 U.S.C.50).

2. Department of the Interior USGS manual (500.1.1), which establishes the policy of the USGS in cooperative work with states, counties, municipalities, and other political subdivisions.

3. OMB Circular A-16, and Presidential Executive Order 12906, April 11, 1994, Coordinating Geographic Data Acquisition and Access: The National Spatial Data Infrastructure (NSDI).

4. Articles of Agreement establishing the Middle Rio Grande Council of Governments executed December 11, 1969, with amendments through December 12, 1996.

5. In case of conflict, the appropriate Federal laws and regulations apply.

\section{Responsibilities}

Specific activities and responsibilities that may be undertaken as part of this agreement are as follows: 
The USGS will:

1. Participate in the MRGCOG LAM design requirements meetings when requested by the MRGCOG.

2. Participate on the MRG Regional Land Use Task Force when requested by the MRGCOG.

3. Participate on the MRGCOG LAM User Acceptance Team when requested by the MRGCOG.

4. Provide 1996 National Aerial Photography Program (NAPP) photographic products, including 1:12,000-scale digital orthophoto quadrangles (DOQ), for specific areas requested by the MRGCOG.

5. Provide the MRGCOG assistance in deriving their land use category for constrained lands or provide the MRGCOG with the raw digital elevation model (DEM) data necessary to derive the land use category.

6. Invite the MRGCOG to attend any USGS workshop regarding landscape change analysis, human-induced land transformations, land-use modeling, or urban dynamics.

The MRGCOG will:

1. Assist the USGS with land use and land cover (LULC) verification during the LULC data compilation activity.

2. Provide converted U.S. Bureau of Reclamation and City of Albuquerque LULC digital data as well as any supporting analog land-use maps for use by the USGS in compiling LULC data.

3. Provide information regarding the attractiveness scores used to code land-use polygons for different development scenarios as well as information regarding the LAM system architecture.

4. To the maximum extent possible, provide the USGS with courtesy copies of the adopted plans, sector plans, and comprehensive plans for all cities and counties within the MRGB land-surface analysis pilot area.

5. Provide (on an as-needed basis) input to the USGS's land-surface analysis, urban dynamics, and land-cover characterization program requirements.

The USGS-NMD, and the MRGCOG will:

1. Exchange digital and (or) analog information (i.e., contemporary and historical) required for either the USGS MRGB Land-Surface Analysis activity or the MRGCOG LAM.
2. Participate in jointly reviewing the Land-Based Classification Standards Project sponsored by the American Planning Association.

3. Exchange the LAM software and the USGS Urban Growth Model software as well as any output-development scenario data-sets for analyzing differences in model results.

4. Exchange 1:100,000-scale and 1:24,000-scale digital raster graphics (DRG) in support of the MRGCOG Focus 2050 Regional Plan and USGS MRGB Study.

5. Exchange LULC classification schemas being implemented for the USGS MRGB study and the MRGCOG regional plan.

\section{Financial Arrangements \\ Funding}

When it becomes necessary that both agencies must exchange funds, then an annex will be prepared to this agreement that cites the existing agreement, the need for funds to be exchanged, funding amount, products and (or) services to be rendered, etc. Both agencies will sign and date the annex. The agreement to exchange funds will not take effect until both parties have signed the annex.

\section{Constraints}

Cost sharing by the USGS-NMD cannot exceed 50 percent of the cooperative project costs.

\section{Coverage}

The amount contributed covers all the necessary field and office work directly related to the program, but excludes any bureau-level general administrative or accounting work.

\section{Period of Agreement}

Effective Agreement

This agreement shall be in effect from the date of the last signature until the USGS MRGB Study and MRGCOG Focus 2050 Regional Plan are complete.

\section{Review Cycle}

This agreement will be reviewed every 6 months, or at the request of either agency, for possible modification, as appropriate.

\section{Modifying or Terminating Clause}

This agreement may be modified at any time upon joint approval, or may be terminated by either agency upon 90 days written notice, or at any time by mutual consent. 


\section{Points of Contact}

Both the USGS and the MRGCOG will designate one individual to serve as the contact for the resolution of technical and production-related questions.

David J. Hester

USGS-National Mapping Division

Box 25046, MS 516

Denver, CO 80225-0046

Tel: (303) 202-4318

Fax: (303) 202-4354

E-mail: dhester@usgs.gov
Stephen J. Burstein

MRGCOG

317 Commercial N.E., Suite 300

Albuquerque, NM 87102-3429

Tel: (505) 247-1750

Fax: (505) 247-1753

E-mail: sburstein@mrgcog.org

\title{
OVERVIEW OF THE FOCUS 2050 REGIONAL PLAN
}

\author{
Dennis R. Foltz, AICP (American Institute of Certified Planners), and Stephen Burstein, AICP \\ Middle Rio Grande Council of Governments \\ 317 Commercial, N.E., Suite 300, Albuquerque, NM 87102
}

The Middle Rio Grande Council of Governments (MRGCOG) has initiated a project called the Focus 2050 Regional Plan, which aims to create a longrange vision and strategy for managing growth and development within the Middle Rio Grande Basin. Economic sustainability is the goal. The year through which the Plan applies is 2050 . The Focus 2050 Regional Plan area comprises Bernalillo, Sandoval, Torrance, Valencia and southern Santa Fe Counties (Fig. 18).

Plan development is scheduled for approximately four years, and consists of eight overlapping activities (Fig. 19). During this second year of Focus 2050, the following components have been accomplished or are in progress: (1) socioeconomic projections to the year 2050; (2) existing-conditions report; (3) existing land-use inventory; (4) urban design/rural character study; (5) completion of the Regional Vision Statement and Goals; (6) development of the Land-Use Analysis Model (LAM); and (7) coordination on regional water planning including the Middle Rio Grande Water Assembly. The Regional Land-Use Task Force, a technical committee made up of MRGCOG appointees, is assisting in developing Focus 2050. Thus far two subcommittees have been formed and are conducting regular meetings: the Linked Regional Open-Space Task Group and the Land-Use Alternatives Subcommittee. Additional subcommittees will be formed during the next year. The Executive Board of MRGCOG, consisting of local government-elected officials, serves as the policy-development board for Focus 2050.

Coordination between MRGCOG and the U.S. Geological Survey (USGS) - National Mapping Division has been helpful to the development of Focus 2050 in numerous ways including: (1) assistance in designing the specifications for LAM; (2) acquisition of selected digital orthophoto data for inventorying existing land-use; and (3) use of slope analysis as a layer of "constrained land" for LAM. In turn, MRGCOG has provided the USGS with products of our study that should assist the Middle Rio Grande Basin Study. Among these are: Existing Land-Use Inventory, Land-Use Analysis Model (LAM), and concept scenarios.

Results-to-date of two of the most important activities of Focus 2050 are outlined below. Both Public Involvement and Land-Use Scenarios synthesize information from the other activities.

\section{Public Involvement}

We conducted the Focus 2050 Regional Visioning process from August 1997 through January 1998. More than 400 participants worked to develop the Vision Statement and Goals through: (1) sets of workshops in each County served by MRGCOG; (2) 


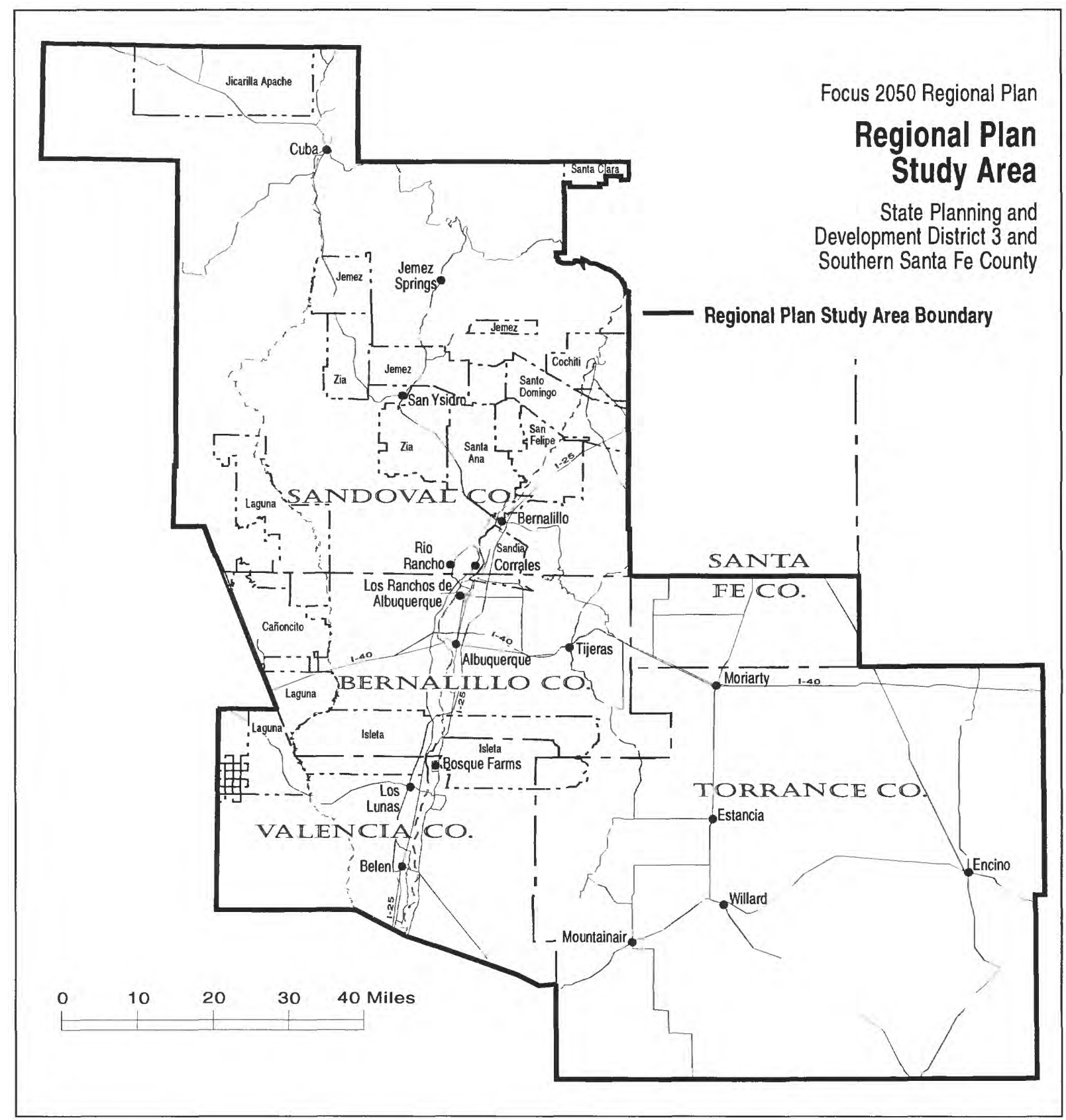

Figure 18. Map showing the Focus 2050 Regional Plan area.

community interviews; and (3) facilitated discussions with planning commissions, local elected bodies and others concerned with long-range development. The MRGCOG Board of Directors adopted the Statement and Goals on January 8, 1998 to guide the Focus 2050 Regional Plan. Future public-involvement events scheduled are the Educational Symposium to coincide with the "long list" of alternative land-use scenarios and the Regionalism Town Hall for public involvement in selecting the preferred land-use alternative.

\section{Land-Use Scenarios}

The Land-Use Analysis Model (LAM) GIS application will be used to draw the alternative land-use scenarios, depict the socioeconomic factors corresponding with land-use change, and allocate the land use and socioeconomic changes based on scoring principles. Transportation, air quality, water, economic development, linked regional openspace, housing and utilities are factors that will influence land-use scenarios in Focus 2050 (Fig. 20). The Land-Use Alternatives Subcommittee, consist- 


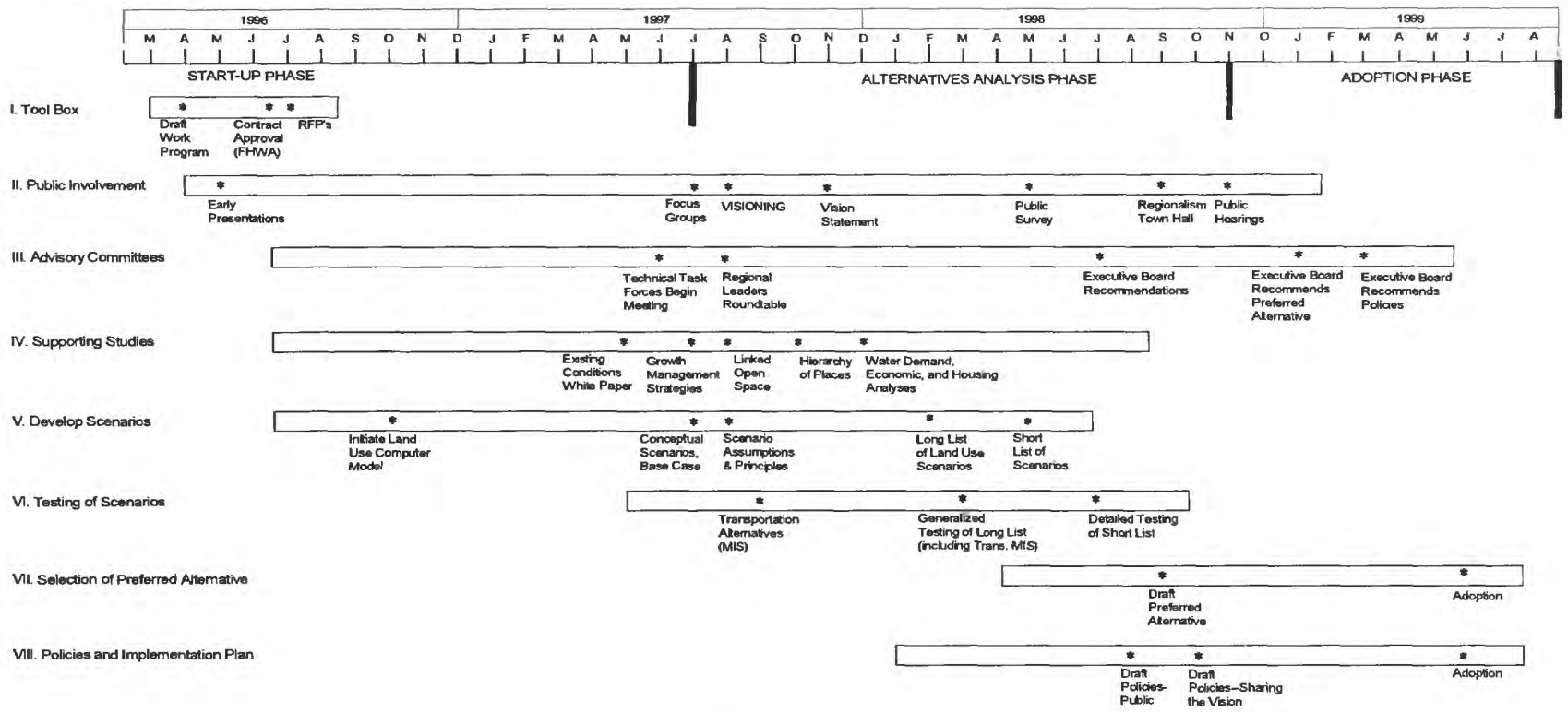

Figure 19. Timeline showing activities scheduled for the Focus 2050 Regional Plan process.

ing of people from cross-disciplinary public and private backgrounds, is currently working on the assumptions and principles that will be depicted in the "long list" of alternative land-use scenarios. This subcommittee will report to the Regional LandUse Task Force, which will make recommendations to the Executive Board of MRGCOG throughout the process. A short list of three or four scenarios will be considered for further evaluation. The preferred alternative may be a combination of some of the best features of several scenarios.

Many groups will use the Focus 2050 Regional Plan; among them are: governmental agencies, non-profit agencies, and businesses and private citizens committed to involvement in regional issues. Local governments may use the plan as a "template" to guide local comprehensive plans. Focus 2050 will be used to guide MRGCOG in such areas as transportation planning, regional water planning, and growth-management technical assistance. The preferred long-use scenario in Focus 2050 will be integrated into the Middle Rio Grande Long-Range Major Transportation Improvement Study being developed by MRGCOG for the Metropolitan Planning Organization.
In conclusion, Focus 2050 links cross-functional planning among multiple jurisdictions in the region. The adoption and implementation of the Regional Plan by local governments will be a meaningful step toward a regional planning effort. Opportunities for collaboration between the MRGCOG and the local government members of the Council of Governments, state agencies, and federal agencies exist within the framework of the Focus 2050 Regional Plan

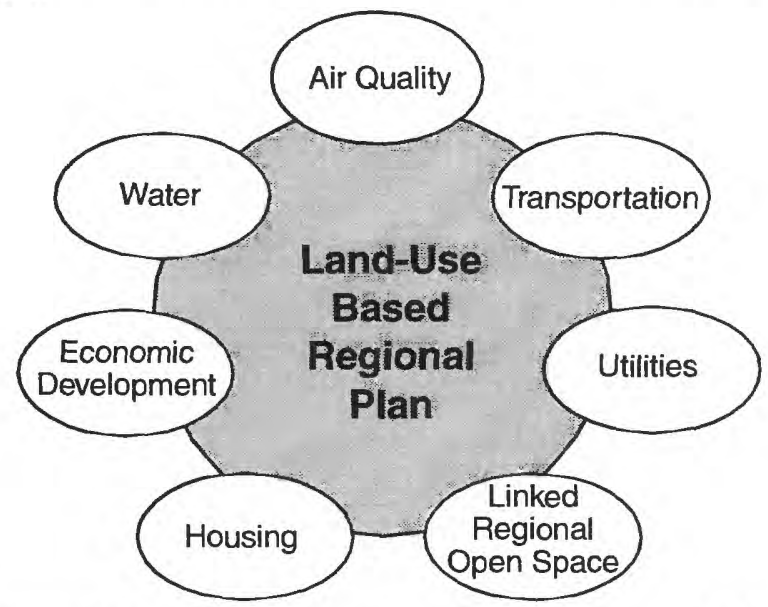

Figure 20. Sketch showing functional plan areas related to the Focus 2050 Regional Plan. 


\section{MIDDLE RIO GRANDE BASIN STUDY PARTICIPATING ORGANIZATIONS}

U.S. Geological Survey - Geologic Division National Cooperative Geologic Mapping Program P.O. Box 25046, MS 913

Denver, CO 80225

U.S. Geological Survey - Water Resources Division New Mexico District Office

4501 Indian School Road, N.E.

Albuquerque, NM 87110

U.S. Geological Survey - National Mapping Division Rocky Mountain Mapping Center

P.O. Box 25046, MS 516

Denver, CO 80225

New Mexico Bureau of Mines and Mineral Resources

801 Leroy Place

Socorro, NM 87801

City of Albuquerque

Public Works Department

Water Resources Management

P.O. Box 1293

Albuquerque, NM 87103

New Mexico Office of the State Engineer

P.O. Box 25102

Santa Fe, NM 87504

Middle Rio Grande Council of Governments

317 Commercial Ave., N.E., Suite 300

Albuquerque, NM 87102

University of New Mexico

Department of Earth and Planetary Sciences

Albuquerque, NM 87131

New Mexico Institute of Mining and Technology

Earth and Environmental Science Department

Socorro, NM 87801 